\title{
Overweight prevention, starting from birth onwards
}

Citation for published version (APA):

Dera - de Bie, E. (2016). Overweight prevention, starting from birth onwards: an evaluation of the development and effect of a training program for child health care practitioners in the Netherlands. [Doctoral Thesis, Maastricht University]. https://doi.org/10.26481/dis.20160706ed

Document status and date:

Published: 01/01/2016

DOI:

10.26481/dis.20160706ed

Document Version:

Publisher's PDF, also known as Version of record

\section{Please check the document version of this publication:}

- A submitted manuscript is the version of the article upon submission and before peer-review. There can be important differences between the submitted version and the official published version of record.

People interested in the research are advised to contact the author for the final version of the publication, or visit the DOI to the publisher's website.

- The final author version and the galley proof are versions of the publication after peer review.

- The final published version features the final layout of the paper including the volume, issue and page numbers.

Link to publication

\footnotetext{
General rights rights.

- You may freely distribute the URL identifying the publication in the public portal. please follow below link for the End User Agreement:

www.umlib.nl/taverne-license

Take down policy

If you believe that this document breaches copyright please contact us at:

repository@maastrichtuniversity.nl

providing details and we will investigate your claim.
}

Copyright and moral rights for the publications made accessible in the public portal are retained by the authors and/or other copyright owners and it is a condition of accessing publications that users recognise and abide by the legal requirements associated with these

- Users may download and print one copy of any publication from the public portal for the purpose of private study or research.

- You may not further distribute the material or use it for any profit-making activity or commercial gain

If the publication is distributed under the terms of Article $25 \mathrm{fa}$ of the Dutch Copyright Act, indicated by the "Taverne" license above, 


\section{Overweight prevention, starting from birth onwards}

An evaluation of the development and effect of a training program for child health care practitioners in the Netherlands

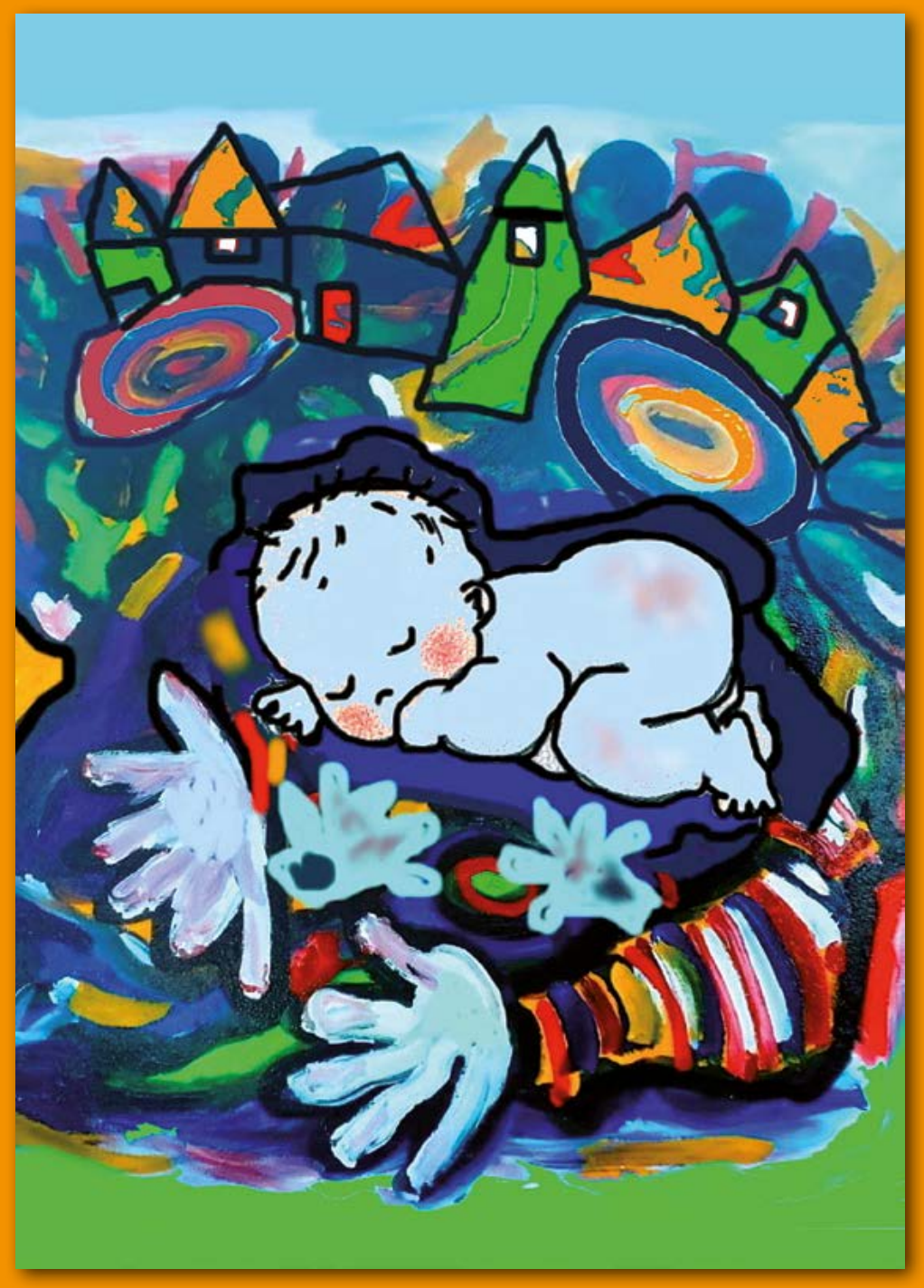

Eveliene Dera-de Bie 
The research presented in this thesis was conducted at the Department of Social Medicine, Maastricht University, the Department of Pediatrics, University Medical Center Maastricht, Child Health Care organization of Envida and the Academic Collaborative Center for Public Health Limburg and South Limburg Public Health Services

We would like to thank all Child Health Care organizations and their practitioners who took part in this study.

The research described in this thesis was funded by the Netherlands Organization for Health Research and Development (ZonMw grant no. 7125.0001).

The publication of this research was financially supported by the Department of Pediatrics, University Medical Center Maastricht and Child Health Care organization of Envida.

Cover design : JC, 2015.

Layout \& printed by: Datawyse / Universitaire Pers Maastricht

(C) Eveliene Dera-de Bie, Maastricht 2016

ISBN 9789461595720

All rights reserved. No part of this publication may be reproduced, stored in a retrieval system or transmitted in any form or by any means electronic, mechanical, photocopying, recording or otherwise, without the prior permission of the author. 


\title{
Overweight prevention, starting from birth onwards.
}

\section{An evaluation of the development and effect of a training program for child health care practitioners in the Netherlands.}

\author{
PROEFSCHRIFT \\ ter verkrijging van de graad van doctor aan de Universiteit Maastricht, \\ op gezag van de Rector Magnificus, Prof. dr. L.L.G. Soete \\ volgens het besluit van het College van Decanen, in het openbaar te verdedigen op \\ woensdag 6 juli 2016 om 12.00 uur \\ door \\ Eveliene Gertrude Eleonora de Bie \\ geboren te Gulpen
}




\section{Promotores}

Prof. dr. ir. M.W.J. Jansen

Prof. dr. L.J.M. Zimmermann

\section{Copromotor}

Dr. W.J. Gerver

\section{Beoordelingscommissie}

Prof. dr. F.J.M. Feron (voorzitter)

Prof. dr. E. Dompeling

Dr. J.S. Gubbels

Dr. M.L.A. de Kroon (Erasmus MC Rotterdam)

Prof. dr. P.J.J. Sauer (UMC Groningen) 


\section{Contents}

CHAPTER 1 General introduction

CHAPTER 2 Inhibiting factors in the prevention of overweight in infants:

An explorative qualitative study among child health care practitioners in the Netherlands

CHAPTER 3 Characteristics of child health care practitioners in overweight prevention of children

CHAPTER 4 Training program for overweight prevention in the child's first year: compilation and results

CHAPTER 5 Early prevention of overweight by child health care practitioners and the effect on the child's growth.

CHAPTER 6 General discussion

CHAPTER 7 References

CHAPTER 8 Summary /samenvatting

Valorisation of the research findings 105

Dankwoord

Curriculum vitae

List of publications 

CHAPTER 1

General introduction 



\section{OVERWEIGHT AND EARLY LIFE}

The prevalence of overweight has increased worldwide in recent decades, reaching epidemic proportions (WHO, 2015). More than $50 \%$ of the world's adult population were overweight in 2014 and 42 million children under the age of 5 were overweight in 2013 (WHO, 2015).

The rising prevalence of overweight, the related diseases and treatment of complications are responsible for spiraling lifetime health care costs, even among children (Finkelstein 2014). In the European region of the WHO, obesity is responsible for $6 \%$ of the national health care costs (Branca et al., 2007). But it is not only costs which should be taken into consideration. More important is a better quality of life during the lifespan of the population as a whole and ensuring better health for future offspring. This certainly also applies to the topic of overweight children.

In the Netherlands, at least half of the general adult population are estimated to be overweight (Schokker et al., 2007). The number of overweight children in the Netherlands almost tripled between 1980 and 2009, and has currently reached a level of 1315\% of all children aged 2 to 21 years (Schönbeck et al., 2011). Overweight among children, which can be defined as "abnormal or excessive fat accumulation", is acknowledged as a major public health concern because of the associated lifelong health consequences and it even contributes to premature mortality (Branca et al., 2007). The major health consequences of overweight are cardiovascular diseases, certain orthopedic disorders and certain forms of cancers (WHO, 2015). An early predictive marker of vascular diseases due to overweight is the metabolic syndrome (L'Allemand-Jander, 2010; Reilly et al., 2011). The prevalence of this syndrome increases with the severity of overweight, and it currently affects about $50 \%$ of severely overweight youngsters. The metabolic syndrome is characterized by a cluster of metabolic risk factors for type 2 diabetes mellitus and cardiovascular diseases (Alberti et al., 2005, 2009). The etiology of the metabolic syndrome is unknown, and its pathophysiology is diverse and complex. The most commonly accepted underlying cause is insulin resistance, although it probably involves a variety of genetic and environmental factors. An increase in insulin resistance leading to cardiometabolic diseases as well as type 2 diabetes has been described to occur even at a young age (Freedman et al., 1999). Barker and colleagues were the first to find a relation between low birth weight and the metabolic syndrome in adulthood (Barker et al., 1989; Gluckman et al., 2008). This assumption is known as the "fetal origins hypothesis" (Barker, 1995). It is clear that an adverse environment in utero cannot be reversed postnatal, and results in an abnormal metabolism (Barker, 2000).

Evidence indicates that in most countries between 20 and $30 \%$ of adults suffer from the metabolic syndrome, and numbers continue to rise (Grundy, 2008). In the future, the syndrome may overtake smoking as the leading risk factor for heart disease (Aguilar et al., 2015; CDC, 2009). Overweight is not only recognized as a contributor to long- 
term chronic diseases and premature mortality, it also has a negative influence on children's physical, emotional and social well-being (Franks et al., 2010; Williams et al., 2005).

The causes of overweight are multifactorial (Seidell \& Halberstadt, 2015; Lobstein et al., 2004). However, the path of growth that leads to overweight already begins during pregnancy and infancy. There are a significant number of risk factors in early life that lead to overweight (Agras et al.,2004; Reilly et al., 2005). One of the intrauterine risk factors that plays an essential role is the lifestyle habits of the mother. Maternal overweight or smoking during pregnancy can affect the growth of the child in utero resulting in insulin resistance after birth (Mesman et al., 2009). This is known as the "fetal insulin hypothesis" On the other hand, Hattersley et al., hypothesized that the association between low birth weight and adult insulin resistance is principally genetically mediated (Hattersley \& Tooke, 1999). Genetically determined insulin resistance is thought to result in low insulin-mediated fetal growth in utero as well as in insulin resistance in adulthood. Hales et al. call this the "thrifty phenotype hypothesis" (Hales \& Barker, 2001).

In addition to low birth weight, maternal overweight and smoking during pregnancy the literature also describes other risk factors for the development of overweight after birth, a rapid postnatal growth, a low socioeconomic status (SES) of the parents, the child's ethnicity and the lifestyle habits of the family, such as food preferences and parental feeding styles (Agras et al., 2004; Reilly et al., 2005). Also, it is not only the lifestyle habits of the mother and her body mass index (BMI) that constitute strong predictors of overweight in children; a high BMI of the father is also known to be a negative factor (Hediger et al., 2001). Evidently, the risk of overweight is influenced not only by genetic factors, but also by environmental, socio-demographic and cultural factors (Seidell \& Halberstadt, 2015).

In Western society, lifestyle habits have changed in recent decades toward more unhealthy dietary behaviors and sedentary and low physical-activity patterns. Today people consume more foods that are high in energy, fats-, and free sugars, all accompanied by too much salt. At the same time, many people hardly consume any fruit, vegetables or dietary fibers, such as wholegrain (WHO, 2015). With regard to the nutrition of newborn children, formula feeding has taken over breastfeeding (Arenz et al, 2004). Even though exclusive breastfeeding seems to have a long- term protective effect against overweight (Arenz et al., 2004; Branca et al., 2007; De Kroon et al., 2011), many infants are overfed with formula feeding based on the idea "the fatter the better" (Anzman et al., 2010; Hester et al., 2012).

Whatever the cause of overweight, it is important to realize that the development of lifestyle habits in early childhood influences body weight during the entire life span 
(Reilly \& Kelly, 2011). When a child is born it needs suitable nutrition and should be stimulated to engage in physical activity as a requirement for optimal growth. After all, the major cause of overweight is a chronically disturbed energy balance, where energy intake exceeds energy expenditure (Doak et al., 2006). This disturbed balance is the cause of overweight in the parents, who at the same time create an obesogenic environment for their child.

For young children, it is especially the parents who lay the foundations for their child's later eating and activity habits. Studies have shown that parents can be supported in achieving effective behavioral change that seems to reduce overweight in children (Campbell \& Hesketh, 2007). Therefore, involving parents is essential for health promoting interventions. However, parents perception of the weight of their child often underestimate the actual weight, and parents often do not recognize overweight as already presenting a "health problem" for their child (Parry et al., 2008). It is possible that this perception is linked to the parents socioeconomic status, because people with a low educational level are more likely to be overweight than people with a high educational level (Roskam \& Kunst, 2008).

Summarizing, once children are overweight it is difficult to reduce their weight to an ideal level, and so it is important to start preventing overweight as soon as they are born (Singh et al.,2008). Health care practitioners are involved in the efforts to stem the childhood overweight epidemic as they have a mediating role toward parents. The focus of the research presented in this thesis was on early detection of children at risk for developing overweight, on supporting parents regarding their actions to help their child develop a healthy lifestyle and on the interventions that can achieve this.

The studies reported on here evaluated the effect of a newly developed, actively implemented training program for the daily practice of child health care $(\mathrm{CHC})$ on the improvement of overweight management from birth onward.

\section{PREVENTION OF OVERWEIGHT AMONG YOUNG CHILDREN}

Attention for prevention has grown in recent decades, and higher standards of care regarding prevention have been published. There is a well-known saying that "prevention is better than cure". Prevention of health problems has a positive effect on public health, as has shown in the case of pregnant women who tend to smoke during pregnancy (Lumley et al., 2009). Most intervention programs have generally proven moderately effective in preventing overweight. They have mostly focused on short-term results, however and evidence for successful prevention of overweight in the longer term is hard to obtain.

Intervening from birth onward, when children are at the most receptive stage of their development offers the potential of permanently altering their development trajectories and protecting them against risk factors present in their early environment 
(Doyle et al., 2009). However, interventions in childhood have traditionally been mainly aimed at older, already overweight children, and not at young children whose weight is still within the normal range. A recent study by Ernst et al. showed the benefits of overweight prevention in the child's first year (Ernst et al., 2014). However, research into young children who tend to become overweight remains scarce.

\section{DUTCH CHILD HEALTH CARE PRACTITIONERS AND OVERWEIGHT PREVENTION}

Many health care organizations and practitioners are involved in childhood weight management. Health care organizations have developed a number of approaches and strategies to facilitate health care practitioners in addressing overweight management. However, there has not been much research into the effect of weight management by health care practitioners in children's early years, with the exception of breastfeeding.

The Netherlands has a unique system providing preventive health care to children aged 0-18 years, offering free systematic monitoring of physical, psychological, social and cognitive health. The child health care $(\mathrm{CHC})$ practitioners support parents regarding the growth of their child and advise them about the development of a healthy lifestyle. The attendance rate of these $\mathrm{CHC}$ visits is over $90 \%$, whereas other health delivery organizations, have a much smaller reach regarding early overweight prevention interventions. $\mathrm{CHC}$ practitioners acknowledge that they have a task to fulfil in preventing children from becoming overweight. At present there is insufficient knowledge on how to protect a child from birth onward, against the risk of becoming overweight and thus against its consequences, such as cardiometabolic diseases. What is the effect of individual counseling of parents by health care practitioners? CHC practitioners still experience barriers in discussing a child's weight management (Mikhailovich \& Morrison, 2007). At the same time, they feel they are insufficiently supported by the literature about improving early overweight management, as they are not familiar with the existing literature (Ashby et al., 2012). Professional practices as well as training and personal experience in preventing overweight are important factors that can influence their attitude and approach. Identifying the attitude of $\mathrm{CHC}$ practitioners and the barriers they experience can help to improve their preventive approach. In addition, organizational support, for example by means of protocols, can influence the practitioners role in fulfillment of their task in overweight prevention. Protocols have been developed, and there is in fact no lack of protocols. The problem is that these protocols are often not correctly used in daily practice. According to the literature, behavioral characteristics of practitioners have the greatest direct influence on the process of protocol implementation and thereby also on its effectiveness (Paulussen et al., 2007).

With respect to early prevention of overweight, $\mathrm{CHC}$ practitioners should be able to detect a child at risk for overweight at an early stage. They have to communicate with 
parents about the risks associated with their child's weight and motivate parents to take action with respect to a healthy lifestyle for their child.

During the regular check-ups by these $\mathrm{CHC}$ practitioners, the height and weight of each child are measured, and the growth charts developed by TNO (2010) are used to determine overweight among children (Schönbeck et al, 2009). The TNO growth chart of children from birth to one year of age reflect predominantly the growth pattern of formula-fed children.

In Dutch CHC, the international age- and sex-specific cut-off points for BMI (body mass index) are used to detect overweight among children between the ages of 2 and 18 years. For children younger than two years, however, there is no practical measurement method to detect children at risk for overweight. For these early years, overweight is defined as +1.881 standard deviation (SD) relative to the reference population (Veldhuis et al., 2009). Early detection of overweight among children is one of the main tasks of the $\mathrm{CHC}$ practitioners. If necessary, they refer to other health care facilities. Since there are no evidence-based interventions for the prevention of childhood overweight in the Netherlands, however, and in view of the increasing prevalence, $\mathrm{CHC}$ has developed a national overweight prevention protocol including the aforementioned cutoff points to address this problem. This protocol describes not only the measurements to detect an overweight child, but it also includes recommendations about a healthy lifestyle, such as reducing the intake of sweet beverages, reducing TV watching and video games, or stimulating breastfeeding. Yet, a recent report suggests that the overweight prevention protocol is having limited effects on the health and BMI of 5-year-old children (Veldhuis et al., 2009).

\section{FACTORS THAT INFLUENCE OVERWEIGHT PROTOCOL IMPLEMENTATION}

The problem is often how to disseminate a protocol in daily practice. Studies have shown that many protocols are designed and implemented without considering how they can be integrated in daily practice (Dunnink, 2013). Historical studies suggest that the development and implementation of protocols does not directly change the behavior of practitioners regarding their implementation in practice.

An effective training program is often necessary to support practitioners in the use of protocols. In addition, strategies with a more theoretically based approach have proved to be more successful, and to contribute to a more appropriate use of protocols in practice (Bartholomew, 2006). Optimized detection of children at risk for overweight and examining what might be helpful in discussing a child's weight with its parents might support $\mathrm{CHC}$ practitioners in their task of offering better lifestyle counseling to parents regarding their young children. This can contribute to a decrease in overweight and related lifetime cardiometabolic risk. In the Netherlands, however, both literature 
and practice indicate that the overweight protocol is not being used as intended in daily practice. In our studies we tried to identify the barriers most commonly experienced by $\mathrm{CHC}$ practitioners in using the overweight prevention protocol. Based on the main results, a training program was then developed to achieve better protocol implementation in practice.

We hypothesized that a more active implementation strategy would have a greater positive effect on the use of the overweight prevention protocol in daily practice by $\mathrm{CHC}$ practitioners. Our research aimed to examine the effect of a more active implementation strategy of overweight prevention, from a child's birth onward.

To address the aims of the research project, we formulated the following questions:

1 What are the factors inhibiting the use of the protocol for overweight prevention among infants by $\mathrm{CHC}$ practitioners?

2 What are the behavioral and personal characteristics of $\mathrm{CHC}$ practitioners which influence the effect of early overweight prevention among children?

3 Does a more actively implemented overweight protocol for a newly developed training program for $\mathrm{CHC}$ practitioners affect protocol adherence in practice?

4. What is the effect of a more actively implemented overweight protocol for $\mathrm{CHC}$ practitioners on the course of weight during children's first two years of life?

\section{THEORETICAL BACKGROUND OF THE RESEARCH}

The research project was based on various relevant theories and models regarding protocol implementation, behavioral change and program development.

With respect to protocol implementation, the theoretical model developed by Fleuren et al. was used as a framework for our studies (Fleuren et al., 2004). Their model offers a useful overview of various factors or "determinants and characteristics" that influence the process of linking an innovation to the actual implementation of an intervention in clinical practice. The model developed by Paulussen was used as an additional theoretical perspective, because of its focus on the characteristics of the $\mathrm{CHC}$ practitioners (Cheater et al., 2005; Paulussen, 1994; Paulussen et al., 2007).

With respect to behavior change, Paulussen's model was applied, which distinguishes five main themes: knowledge and attitude, self-efficacy, task division, willingness to use and actual use of protocols and related educational materials, and support from the organization. In addition, we used the ASE (Attitude, Social norms and influence and self-Efficacy) model (De Vries \& Mudde, 1998) to further explain the behavior of the $\mathrm{CHC}$ practitioners.

With respect to the development of a training program, we used the systematic approach for program development called Intervention Mapping (Bartholomew et al., 2006). The relevant theories selected for the training program were primarily adapted from Bandura's Social Cognitive Theory, Weinstein's Precaution Adaptation Process 
Model, the Elaboration Likelihood model, and the models developed by Fleuren and Paulussen (Bandura, 1986, 2004; Bartholomew et al., 2006; Fleuren et al. 2004).

\section{OUTLINE OF THIS THESIS}

The inhibiting factors experienced by $\mathrm{CHC}$ practitioners regarding their current practice with respect to early overweight prevention were explored in a qualitative study (Chapter 2), after which a self-reported questionnaire was developed to investigate the barriers encountered by $\mathrm{CHC}$ practitioners and the organizational preconditions required to apply the protocol in daily $\mathrm{CHC}$ routine (Chapter 3 ).

Based on the results of the first two studies, we developed a training program to address these barriers and to ensure a more adequate implementation of the overweight prevention protocol (Chapter 4). This training program focused on improving CHC practitioners' knowledge about the importance of overweight prevention starting from birth, and their skills in communicating with parents about childhood overweight. We then performed a study to see whether early intervention by $\mathrm{CHC}$ practitioners is effective in terms of influencing growth in a child's first two years of life in order to prevent overweight later in life (Chapter 5).

Finally, Chapter 6 discusses the results and implications (Chapter 6 ). 



\section{CHAPTER 2}

Inhibiting factors in the prevention of overweight in infants:

An explorative qualitative study among child health care practitioners in the Netherlands 


\section{ABSTRACT}

The aim of this study was to explore inhibiting factors in the prevention of overweight in infants younger than one year, among practitioners working for municipal child health care $(\mathrm{CHC})$ organizations in the Netherlands.

Twelve in-depth interviews with $\mathrm{CHC}$ physicians and nurses were conducted. All interviews were tape-recorded, after which the transcripts were thematically analyzed. Two investigators independently coded two transcripts to verify coding and a final code book was developed. Finally, general conclusions were drawn from the interviews.

The findings indicated that CHC practitioners are insufficiently aware that a child's first year is an important period to prevent overweight, and that they find it difficult to discuss the topic with parents. Additionally, the findings suggest that the current local overweight prevention protocols in the Netherlands are not well implemented.

This study indicates opportunities to improve the performance of $\mathrm{CHC}$ practitioners with respect to the early identification of infants at risk for overweight, as well as the communication of this risk to parents and the implementation of overweight prevention protocols.

Keywords: qualitative, practitioner, child, prevention and overweight 


\section{INTRODUCTION}

The increasing worldwide prevalence of overweight and obesity has reached epidemic proportions and has become a major public health problem (WHO, 2000). Overweight occurs not only among adults but also among children (Ebbeling et al., 2002). The prevalence of overweight in children in the Netherlands almost tripled between 1980 and 2010, and currently is $14 \%$ (van den Hurk et al., 2007; Schönbeck \& van Buuren, 2010, Schönbeck et al. 2011). In the Netherlands, for the age range 2-18 years, the body mass index (BMI) cut-off points are used to determine if a child is overweight or obese (Cole et al., 2000, 2007). For children younger then two years overweight is defined as $\geq$ $+1 \mathrm{SD}$ and obesity as $\geq+2 \mathrm{SD}$ of the reference population.

The adverse health consequences, such as metabolic syndrome and psychosocial problems, are frequently described (Freedman et al., 2001; Reilly et al., 2003, 2011). Several studies show that an abnormal pattern of weight in the prenatal and early postnatal period is predictive of the development of overweight in later life (Barker, 2007; Gluckman \& Hanson, 2004; Hales, 2001). Compared to children with normal weight, overweight children are twice as likely to become overweight adults (Singh et al., 2008). Moreover, the development of lifestyle habits in early childhood influences body weight during the entire life span, and once a child is overweight, it is difficult to reduce it to an ideal weight (Kelder et al., 1994). It is in early childhood that parents lay the foundations for their child's later eating and activity habits (Savage et al., 2007). Moreover, it is known that overweight runs in families and that parental obesity is a strongly related factor associated with the overweight risk of an infant (Reilly et al., 2005). Besides, parent's nutrition and physical activity behavior influence the habits of their children. Because, a parent serves as a model for the developing child, it is important that interventions to prevent overweight in children should include the parents. Also, since overweight at a young age tends to persist into adulthood, prevention should start as early as possible, preferably in the first year of life (Lake et al., 1997). Although there is evidence that early prevention is important there are only a few studies which focus on the benefits of overweight prevention in the child's first year (De Kroon et al., 2011). Parents can improve their behavior by breastfeeding their child and parenting with respect to a healthy lifestyle (Gerards et al., 2011; Stolzer, 2011).

In the Netherlands, there is a child health care $(\mathrm{CHC})$ system that supports parents through the provision of a free nationwide program of preventive health checks for their child (0-18 years). The $\mathrm{CHC}$ services also monitor more than 95\% of Dutch children during their first year of life in a series of nine consultations (Wieringen \& Wieren, 2010). The CHC practitioners, physicians and nurses, working for the municipal CHC organizations assist parents and provide advice on proper nutrition, useful physical activity and ways to establish conditions for the child's optimal growth and development. The preventive activities implemented by the municipal $\mathrm{CHC}$ organizations are described in a national document (Dunnink \& Lijs-Spek, 2008), which distinguishes five 
different preventive activities regarding overweight. The first important activity is monitoring the growth of the child and early detection of abnormal growth patterns. The other four preventive activities relate to identifying overweight children, preventing overweight, advising parents about nutrition for children aged $0-4$ years and supporting breastfeeding. Most of the Dutch municipal CHC services have incorporated these activities into their own organizational protocol. However, the implementation of this local overweight protocol tends to be inadequate. Proper implementation of protocols is limited by a number of barriers, such as lack of knowledge, lack of skills and lack of time (Grol, 2001; Story et al., 2002).

It is known that actual success of the application of an innovation, such as the overweight protocol, is maximized if it is introduced systematically. The theoretical model developed by Fleuren et al. is used as a framework in this study (Fleuren et al., 2004, figure 1). Their model offers a useful overview of various factors or 'determinants and characteristics' that influence the process, linking an innovation to the actual implementation of an intervention in clinical practice. The model states that the success of application of an innovation depends on how the implementation strategy is tailored to the influencing characteristics. It distinguishes four main types of characteristics that influence an innovation process: (1) characteristics of the socio-political context; (2) characteristics of the organization; (3) characteristics of the innovation; and (4) characteristics of the adopting person. Indeed, characteristics of $\mathrm{CHC}$ practitioners, e.g., their attitude, beliefs, knowledge, self-efficacy and skills, affect successful protocol application (Paulussen, 1994). CHC practitioners seem to rely predominantly on their own professional experience rather than on a protocol (Fleuren \& de Jong, 2006). So far, little information is available about the characteristics of $\mathrm{CHC}$ practitioners and how these characteristics influence the implementation of overweight prevention activities in routine practice. Besides, the relationship between professionals and parents has changed in recent times. More than ever, parents are able to competently discuss complex medical issues with practitioners because of increased public access to information (e.g. through the Internet). In addition, product developments have resulted in a huge and constantly changing fast food market. These products are affordable for most parents in the Netherlands. However, $\mathrm{CHC}$ practitioners find it difficult to advice them because it is almost impossible to keep knowledge about product composition up-to-date.

The present study tried to explore the characteristics of the adopting persons (e.g. the $\mathrm{CHC}$ practitioners) by identifying their perceptions on the prevention of overweight in routine practice. Improving the efficacy of overweight prevention in CHC consultations requires more information regarding current practice at the $\mathrm{CHC}$ services and the content of the consultations with parents (Schuller, 2006, 2009). In particular, it is important to identify inhibiting factors that influence overweight prevention by $\mathrm{CHC}$ practitioners. We therefore undertook an explorative qualitative study to investigate the clinical practice of $\mathrm{CHC}$ practitioners with respect to the prevention of overweight in infants younger than one year of age. 


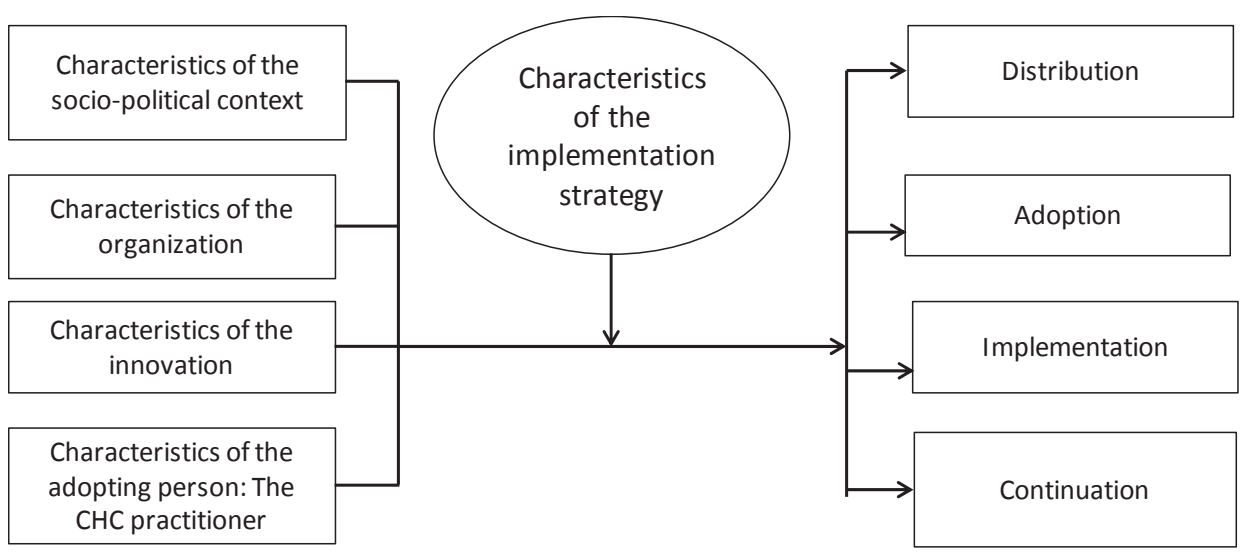

Figure 1. Model van Fleuren et al., 2004

\section{METHOD}

A purposive sample of 12 participants (six nurses and six physicians) was recruited. The local manager selected participants in such a way that there would be sufficient variation in participant characteristics. Participants were selected on the basis of occupation (physician or nurse), working environment (urban or rural area, low or high socioeconomic area), age and the number years they had been in their present occupation. The 12 selected participants were drawn from a total of $105 \mathrm{CHC}$ practitioners working in municipal CHC services in the Southern Limburg district of the Netherlands. These organizations are all similar in terms of structure and services.

All participants were invited for a face-to-face in-depth interview, for which a qualitative semi-structured interview topic list was developed focusing on the following items: (1) personal characteristics of the practitioner (e.g. age, gender, years of work experience); (2) current overweight prevention practices; (3) detecting infants at risk for overweight; (4) implementation of overweight prevention protocol; (5) discussing the risk of overweight with parents, (6) overweight interventions; (7) personal perceptions of the prevention of overweight; (8) external factors that facilitate (e.g. skills training) or impede (e.g. time constraints) overweight prevention. Interviews were undertaken until data saturation was reached. The interviews, which lasted approximately one hour, were conducted between October and December 2007. All interviews were taperecorded, with the respondents' permission and analyzed by using qualitative content analysis.

The recordings were first transcribed by the first author and a code was attached to each statement to describe the meaning or context of that statement. The codes included topics such as nutrition, physical activity, behavior, growth, clinical observation, individual aspects of the child, aspects of the parents and the environment. A coding 
system in the form of a tree diagram was then developed to structure the codes, and themes were identified. To test the inter-rater reliability, two investigators independently read two transcripts and identified themes, codes and sub-codes present in the interviews. Then they related the findings to the coding system that had been developed. This resulted in kappa values of 0.66 and 0.75 . Differences in themes and codes were discussed until consensus was reached, and a definitive code book was developed (table 1). This was then used to code the remaining information. Finally, general conclusions were drawn from the interviews.

Table 1. Themes, Codes and sub-codes of the tree diagram

\begin{tabular}{|c|c|c|}
\hline Themes & Codes & Sub-codes \\
\hline \multirow[t]{4}{*}{ 1. General information } & 1.1. Function & \\
\hline & 1.2. Years of Work & \\
\hline & 1.3. Age & \\
\hline & 1.4. Working area & \\
\hline 2. General information about (early) & 2.1.General information & \\
\hline prevention of overweight & 2.2.Primary Prevention & \\
\hline \multirow[t]{10}{*}{ 3. Early Detection } & 3.1. Nutrition & 3.1.1. Artificial feeding \\
\hline & & 3.1.2. Breastfeeding \\
\hline & & 3.1.3. Supplementary Food \\
\hline & 3.2. Physical activity & \\
\hline & 3.3. Clinical view & \\
\hline & 3.4. Behavior / Predisposition & 3.4.1. Child \\
\hline & & 3.4.2. Parent \\
\hline & & 3.4.3. Environment \\
\hline & & $\begin{array}{l}\text { 3.4.4. Interaction parent and } \\
\text { child }\end{array}$ \\
\hline & 3.5.Growth & \\
\hline \multirow[t]{12}{*}{ 4. Discussing overweight } & 4.1. Nutrition & 4.1.1. Artificial feeding \\
\hline & & 4.1.2. Breastfeeding \\
\hline & & 4.1.3. Supplementary Food \\
\hline & 4.2. Physical activity & \\
\hline & 4.3. Behavior / Predisposition & 4.3.1. Child \\
\hline & & 4.3.2. Parent \\
\hline & & 4.3.3. Environment \\
\hline & & $\begin{array}{l}\text { 4.3.4. Interaction parent and } \\
\text { child }\end{array}$ \\
\hline & 4.4.Growth & \\
\hline & 4.5. Advices & \\
\hline & 4.6. Use word overweight or obesity & \\
\hline & 4.7. Risk factors & \\
\hline
\end{tabular}




\begin{tabular}{|c|c|c|}
\hline Themes & Codes & Sub-codes \\
\hline \multirow[t]{9}{*}{ 5. Use of protocol and additional tools } & $\begin{array}{l}\text { 5.1. Activity relate to prevention of } \\
\text { overweight }\end{array}$ & \\
\hline & 5.2. Nutrition guideline for children & \\
\hline & age $0-4$ years & \\
\hline & 5.3. Guideline Healthy Feeding & \\
\hline & 5.4. Guideline Breastfeeding & \\
\hline & 5.5. Early detection guideline & \\
\hline & 5.6. Use of digital child record & 5.6.1. Monitoring Growth \\
\hline & & 5.6.2. Registrations \\
\hline & 5.7. Additional Tools & \\
\hline 6. Intervention & 6.1. Performed an intervention & \\
\hline \multirow[t]{9}{*}{ 7. Insight } & 7.1. Nutrition & 7.1.1. Artificial feeding \\
\hline & & 7.1.2. Breastfeeding \\
\hline & & 7.1.3. Supplementary Food \\
\hline & 7.2. Physical Activity & \\
\hline & 7.3. Behavior/ Predisposition & 7.3.1. Child \\
\hline & & 7.3.2. Parent \\
\hline & & 7.3.3. Environment \\
\hline & & 7.3.4. Interaction parent -child \\
\hline & 7.4. Growth & \\
\hline \multirow[t]{5}{*}{ 8. Internal factors } & 8.1. Knowledge & \\
\hline & 8.2. Self-efficacy & \\
\hline & 8.3. Competence & \\
\hline & 8.4. Task Division & \\
\hline & 8.5. Attitude & \\
\hline \multirow[t]{3}{*}{ 9. External factors } & 9.1. Support organization & \\
\hline & 9.2. Support colleagues & \\
\hline & 9.3. Cooperation partners & \\
\hline 10. Change code & $\begin{array}{l}\text { 10.1. What would the practitioner } \\
\text { like to change }\end{array}$ & \\
\hline \multirow[t]{6}{*}{ 11. Inhibiting factors } & 11.1. Insights & \\
\hline & 11.2. Discussing the topic & \\
\hline & 11.3. Support & \\
\hline & 11.4. Early detection & \\
\hline & 11.5. Practical factors & \\
\hline & $\begin{array}{l}\text { 11.6. Factors related to child, parent } \\
\text { or environment }\end{array}$ & \\
\hline
\end{tabular}




\section{RESULTS}

\section{Personal characteristics}

The mean age of the practitioners included in this study was 44 years and the mean number of years they had been working in $\mathrm{CHC}$ was 17 years. All respondents were female (table 2).

Table 2. Characteristics of CHC Physicians and Nurses who were interviewed

\begin{tabular}{|c|c|}
\hline Characteristics & $(\mathrm{N}=12)$ \\
\hline \multicolumn{2}{|l|}{ Profession* } \\
\hline CHC Physician & 6 \\
\hline CHC Nurse & 6 \\
\hline Female* & 12 \\
\hline Age & Mean = 44 years (SD 24-62) \\
\hline$<30$ years & 1 \\
\hline $30-50$ years & 7 \\
\hline$>50$ years & 4 \\
\hline Years of Profession & Mean = 17 years $(S D 2-34)$ \\
\hline$<10$ years & 5 \\
\hline 11-19 years & 2 \\
\hline$>20$ years & 5 \\
\hline \multicolumn{2}{|l|}{ Working environment } \\
\hline Urban & 6 (3 physicians and 3 nurses) \\
\hline Rural & 6 (3 physicians and 3 nurses) \\
\hline Low Socioeconomic Area & 8 (3 physicians and 5 nurses) \\
\hline High Socioeconomic Area & 4 (3 physicians and 1 nurse) \\
\hline
\end{tabular}

\section{Current practice and detecting infants at risk for overweight}

All respondents used standardized national reference curves for height and weight according to age to evaluate the growth of infants and to detect abnormal growth patterns. The respondents reported giving consistent attention to feeding patterns and their possible impact on growth. When a disproportional increase in the child's weight to length ratio was noted, they would use a wait-and-see approach with regard to discussing this with the parents and with regard to applying any intervention. Ten of the 12 
respondents were unaware of the relation between growth in the first year of life and the risk of overweight in later life.

"I am not convinced whether the first year of a child's life is predictive for overweight in adulthood." (Nurse, 1)

All respondents reported finding it difficult to focus on overweight prevention in infants under a year because it is not clear when a given weight implies an increased risk for the infant. Nonetheless, several actual risk factors for developing overweight were mentioned: (1) the infant has a family member who is overweight, (2) the infant cries excessively, and (3) the infant belongs to a family with low socioeconomic status. Additionally, parents who are unaware that the first year of life is important for the development of healthy eating and activity habits - i.e. parents who function as 'unhealthy role models' - were also considered a risk factor.

"The largest risk is probably when obese parents do not consider overweight problematic. Many suppose that because of their own overweight, their children will also be overweight. These parents will not change their lifestyle." (Nurse, 3)

\section{Perceptions}

Of the 12 practitioners in this study, 10 did not consider overweight in the first year of life to pose real problems for weight in later life.

\section{Applying overweight prevention protocols}

None of the respondents reported using the existing overweight protocol as prescribed, with the exception of the topic of breastfeeding. For this, several reasons are mentioned, such as a lack of awareness, the content is not linked enough to the child's first year or there is to less time to get familiar with the protocol. As regards feeding practices, they mentioned portion size, diet composition and the age at which fast food is introduced as factors that can affect weight.

"I always check child's nutrition. Then I check if they are already started with supplementary feeding, hoping that they will delay it, but if they do want to start it, I check whether it is the right kind of nutrition. Often parents have already started with supplementary feeding, for example with cereal or other snacks. Parents are afraid that the child drinks does not drink enough and therefore they also offer additional nutrition, such as soft drinks." (Nurse, 1) 
"I often notice that parents offer solid nutrition rather late. They offer readymade mashed nutrition for a long period and because of that, children do not learn to chew and taste fast food." (Physician, 3)

Breastfeeding was considered best for the infant. Inadequate physical activity (e.g. poor crawling skills) was mentioned as a risk factor by only three respondents. All respondents regarded providing tailored care and having good contact with the parents as much more important than following any protocol.

"I am not the kind of person who closely follows protocols. I try to tailor my advices to what fits into the parent's lifestyle." (Physician, 5)

Six respondents reported having noticed differences between their colleagues regarding the overweight prevention recommendations they provide and the referrals they make.

\section{Discussing the risk of overweight with parents}

All respondents, except one, indicated that discussing overweight with parents was difficult because it is an emotionally charged topic.

"The subject of overweight is difficult to discuss, because when you tell an overweight mother her child is overweight, you indirectly tell the mother she is too." (Nurse, 3)

"Yes, that's the whole problem with overweight. It always feels like a personal message to the parents. I am always very careful to discuss this topic with parents." (Physician, 1)

The most frequent barrier to communicating overweight risk was that the respondent had experienced resistance from parents in the past. This was particularly the case with overweight or obese parents and parents with low socioeconomic status. Six respondents indicated that they found it very difficult to use the term overweight or heavy. They preferred to discuss overweight in terms of the weight not being in line with the normal values on the growth curve. Almost all respondents claimed that they would hesitate to use the words overweight or obesity in their consultations with parents. Most respondents conveyed uncertainty regarding the effectiveness of their recommendations.

"However, when parents are strongly opinionated, sometimes consultation is not more than advice, because you can't force parents to follow your advice." (Nurse, 3) 


\section{Overweight interventions}

The respondents mentioned that, once an infant has been identified as being overweight or at risk for overweight, a variety of interventions and referral pathways can be employed. However, there was no uniformity regarding the kind of interventions or when and to whom the respondents referred. In fact, there was little consensus regarding who should apply interventions and to whom overweight infants should be referred. Respondents mentioned a broad range of professionals, including pediatricians, general practitioners, midwives, physical therapists, dieticians and the infants' day care centers.

"Actually, there is no cooperation with pediatricians and family doctors concerning the topic overweight. "(Physician, 6)

"Yes, the dietician or physiotherapist, but that's what I am thinking in present. However, I don't know which programs they have for example to stimulate physical activity for the young child." (Physician, 1)

\section{Inhibiting characteristics of the practitioners}

All respondents mentioned that practitioners need additional support to improve their communication skills, especially for cases in which parents do not believe their child is overweight or at risk for overweight. Also, although all expressed the opinion that overweight prevention was part of their job, ten of the respondents reported that they tended not to focus on overweight in infants under one year of age. They considered overweight to be an issue only after the first year. All respondents also mentioned that they lacked sufficient time to engage in adequate overweight prevention.

"Another question is whether there is enough consultation time. There are a lot of topics to which attention has to be paid during the consultation with parents. Time is a restrictive factor, but this also counts for more topics."(Physician, 5)

More specifically, they mentioned a discrepancy between the amount of time they were allocated for a consultation and the amount of time they need to complete all tasks prescribed for the consultation. Additionally, half of the respondents indicated that many new developments had occurred in their municipal $\mathrm{CHC}$ organization and that they needed additional time to incorporate new tasks into their work. Accordingly, they reported a need for more support from the organization, for instance in the form of training courses in communication skills and in the implementation of protocols. 


\section{DISCUSSION}

This study aimed to explore inhibiting factors in the prevention of overweight among infants, by interviewing $\mathrm{CHC}$ practitioners working for municipal $\mathrm{CHC}$ organizations. Three major impeding factors were identified. First, the practitioners appear to be unaware that overweight prevention should be applied to infants less than one year of age. Perhaps this is because practitioners do not come into contact with many overweight infants this young and are thus unaware that they should actively try to identify infants at risk for overweight. This lack of awareness may also be exacerbated by the fact that no adequate measure of overweight has been developed for infants under one year. At present there is not much information regarding practitioner's practices in the child's first year related to prevention of overweight.

Second, $\mathrm{CHC}$ practitioners find it difficult to communicate and discuss the risk of overweight with parents. The topic is emotionally charged and parents often express resistance, perhaps because comments about the weight of their child are taken as personal criticism (Mikhailovich \& Morrison, 2007). Third, CHC physicians and nurses in our study inadequately implemented the overweight prevention protocol. The successful use of protocols depends, to a large extent, on the way they are implemented, how well they are applied and whether or not they generate good outcomes. Unfortunately, the implementation, application and outcomes seem to be systematically inadequate in the CHC organizations in our study (Fleuren, 2010). CHC practitioners are important mediators when it comes to motivating and supporting parents in developing a healthy lifestyle for their child, because they know the child's medical and family history. Furthermore, $\mathrm{CHC}$ practitioners play an essential role in detecting infants at risk for overweight. In our study, practitioners appeared to be aware of potential risk factors for child overweight, such as the weight of the parents or the protective factor of breastfeeding. However, the relation between risk factors and managing lifestyle overweight risk factors of infants by behavioral change of parents appeared not to be routine in practice.

When $\mathrm{CHC}$ practitioners endeavor to support parents in raising their children, they must recognize that prevention of overweight can best be initiated in the first year of life, and those infants at risk for overweight need to be identified as early as possible. The current measures used in practice for determining overweight (e.g. Body Mass Index) are often only applied when a child is already overweight (Cole et al., 2000). Another measure that can be used to determine overweight is the clinical picture or the symptoms with which a child presents. However, results of previous studies suggest that practitioners and parents often incorrectly identify an overweight child when they rely on clinical observation alone (Carnell et al., 2005; Smith et al., 2008). A good practical measure for identifying the risk of overweight in an infant's first year would thus be useful and could also support CHC practitioners. 
The challenge for $\mathrm{CHC}$ practitioners will be early detecting an infant at risk for overweight and influence parents beliefs regarding current treats for an infant's health in order to change parenting practices.

In addition, research into the implementation of the overweight prevention protocol in CHC practice is still in its infancy (Veldhuis et al., 2009). This is why the present study focused on the characteristics of the adopting persons (i.e. CHC physicians and nurses).

Furthermore, protocols are developed to assist practitioners about appropriate health care for specific health issues. Although, a protocol should be flexible enough to deliver tailored care, it prevents for example parent's confusion about different advices. A problem is that, at this point in time, each municipal $\mathrm{CHC}$ organization independently translates the national recommendations for preventive activities into a local protocol. Consequently, there is a lack of harmony in the implementation of these preventive interventions and the use of the overweight protocol (Hearn et al., 2008).

National guidelines that describe how prevention should be implemented may therefore be beneficial. The development of these national guidelines should be supported by a guideline tool that describes quality aspects and implementation activities for $\mathrm{CHC}$ organizations on "how to implement a specific guideline". Also, the possibilities of these organizations, the competence of their practitioners and financial aspects should be taken into account. In this respect, the process linking the development of a protocol with its application in practice could be facilitated by an official supervisor, who should coordinate not only the implementation of the overweight protocol, but also ensure further optimization of the protocol and its use in routine $\mathrm{CHC}$ practice.

At the same time, it must be recognized that the successful implementation of a protocol rests not only with national-level actors and organizational managers but also with those who actually implement the protocol in practice, that is, the $\mathrm{CHC}$ practitioners. The overweight protocol must take these issues into consideration and must help practitioners discuss overweight with parents even when parents express resistance. If successful, parents will be better informed and better supported in their efforts to develop a healthy lifestyle for their child(ren). This view is supported by a number of studies that have shown that parents are indeed receptive to and capable of making behavioral changes that may promote an ideal weight for their child (Campbell \& Hesketh, 2007; Savage et al., 2007).

The present study was rooted in both theory and practice. It was conducted among physicians and nurses working in the field and was based on consultations with experts, both academic and practice-based. The findings are very similar to those of studies conducted in other areas in the Netherlands (Brink-Melis, 2009; Boere-Boonekamp et al., 2008), so it appears that the 12 participants included in this study are sufficiently representative of their professional community. 


\section{CONCLUSION}

In conclusion, this study has shown that the early identification of infants prone to develop overweight is currently inadequate, that improvements in the communication of overweight risk to parents are necessary and that the implementation of the national overweight protocol in the Netherlands requires more guidance and supervision.

Awareness, knowledge and communication skills are important elements to improve the risk of overweight in the first year of their child's life. We suggest that training courses for practitioners and guided practice addressing awareness and communication skills regarding overweight prevention of infants could improve the performance of CHC practitioners.

\section{KEY MESSAGES}

$\mathrm{CHC}$ practitioners seem to be unaware of the importance of prevention of overweight in the child's first year.

In order to address the problem of excess weight gain, $\mathrm{CHC}$ practitioners need more guidance and support in the early detection of children at risk for overweight, as well as in discussing the topic with parents and use the overweight protocol in practice. 


\section{CHAPTER 3}

Characteristics of child health care practitioners in overweight prevention of children 


\section{ABSTRACT}

Objectives: To identify behavioral and personal characteristics of child health care $(\mathrm{CHC})$ practitioners that influences the effect of early overweight prevention in children.

Methods: In total 216 questionnaires were filled out by $\mathrm{CHC}$ practitioners from four organizations in the Netherlands.

Results: There is a gap between awareness of the problem overweight in early childhood and actually discussing this with parents, as well as a gap between the existing recommendations and the perceived importance of early overweight prevention. Despite the fact that nurses have a more central task in lifestyle support than physicians, they reported to have less knowledge and skills than physicians.

Conclusions: While both $\mathrm{CHC}$ physicians and nurses need support in improving their knowledge and skills, it is the nurses who need more support. A more structured and tailored implementation strategy with more emphasis on the needs of the nurses and physicians may improve early overweight management.

Keywords: prevention, overweight, child health care, nurses, children.

\section{Highlights of the study}

- $\quad$ Dutch $\mathrm{CHC}$ practitioners still experience barriers in child weight management

- The overweight protocol is not applied as intended and more organizational support is necessary

- The awareness of the importance of overweight management from birth on can be improved

- $\quad$ Nurses need more support than physicians in knowledge about overweight in early childhood

- $\quad$ Nurses need more support than physicians in risk communication skills 


\section{INTRODUCTION}

Overweight in children is recognized as a major public health problem (WHO, 2000). In the Netherlands, the prevalence of overweight in children almost tripled between 1980 and 2010, and currently 14\% of all children are overweight (Schönbeck \& van Buuren, 2010; Schönbeck et al., 2011). The problem of overweight in childhood is that an overweight child is prone to become an overweight adult (Reilly \& Kelly, 2011). Overweight is associated with a higher risk of chronic diseases such as cardiovascular disorders or psycho-social problems (L'Allemand-Jander, 2010; Freedman et al., 2001). The challenge is to start overweight prevention in childhood, but existing intervention programs have shown disappointing results as regards long-term effects (Haynos \& O'Donohue, 2012). The programs mostly focus on older children and often fail to support young children from becoming overweight. It is especially for these younger children that the parents are important role models, as they lay the foundations for a healthy lifestyle for their child (Scaglioni et al., 2011). Food preferences and habits established in childhood tend to be maintained in adulthood. In addition, several studies suggest that parents are indeed capable of changing their children's behavior and lifestyle in a healthy direction (Boere-Boonekamp et al., 2008). Hence, prevention of overweight among children should start as early as possible, and parents must be involved in this process.

In the Netherlands, physicians and nurses working for the child health care (CHC) organization are the main professionals delivering preventive care to children. Each $\mathrm{CHC}$ service is facilitated and financed by the local government. It monitors the growth and development of almost every child by means of a nationwide program of examinations administered at predetermined ages. The $\mathrm{CHC}$ practitioner knows the medical and family history and the current living conditions of both family and child. The fact that over 95\% of Dutch children between 0 and 18 years of age participate in the $\mathrm{CHC}$ program means that the $\mathrm{CHC}$ practitioners can play an essential role in detecting infants at risk for overweight and in motivating parents regarding the development of a healthy behavior lifestyle for their child (Dunnink \& Lijs-Spek, 2008).

However, both the relevant literature and practical experience suggest that the overweight prevention protocols that the $\mathrm{CHC}$ has developed so far are not effectively administered (Fleuren \& De Jong, 2006). There are various factors, 'determinants' or 'characteristics', that can create a gap between the process of developing preventive programs and their actual use (Fleuren et al., 2004). According to the literature, behavioral characteristics of $\mathrm{CHC}$ practitioners have the most direct influence on this process, but limited information is available to show which characteristics of $\mathrm{CHC}$ practitioners are important (Paulussen et al., 2007; Cheater et al., 2005). For our theoretical perspective the model of Fleuren (2004) is combined with the developed model by Paulussen (2007) (Figure, 1). This model is also used, because of its focus on the characteristics of the CHC practitioners. Paulussen's model distinguishes five main themes in the process of behavior change: knowledge and attitude, self-efficacy, task division, willingness to use and actual use of 
protocols and related educational materials, and support from the organization. In addition, we used the ASE (attitude, social norms and influence and self-efficacy) model (De Vries \& Mudde, 1998) to further explain the behavior of the $\mathrm{CHC}$ practitioner.

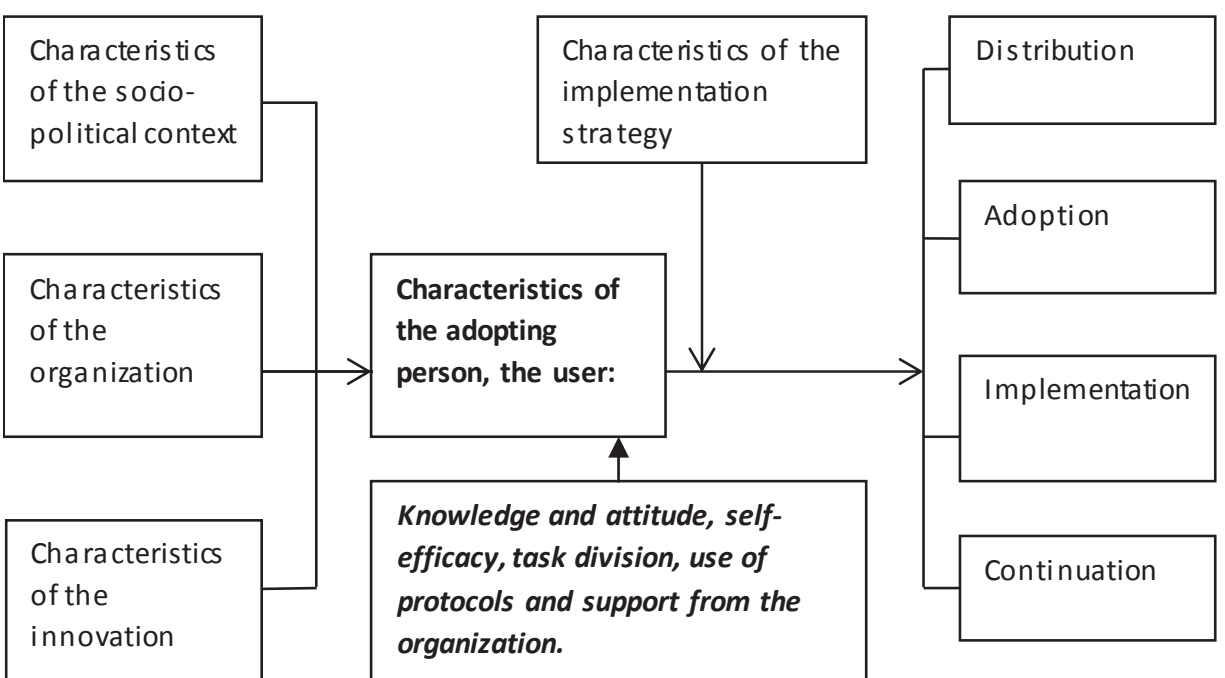

Figure 1. Model Determinants of Innovation processes

(Fleuren 2004; Paulussen 2007)

The aim of the present study was to identify particularly the practitioner-related behavioral and personal characteristics that influence overweight prevention management. Specifically, the study addressed on the following two research questions and four subquestions:

- What are the behavioral characteristics relating to $\mathrm{CHC}$ practitioners and their organization that influence the performance regarding overweight prevention management in daily practice?

- To what extent are $\mathrm{CHC}$ practitioners aware of the importance of early overweight prevention?

- What factors determine whether and how they discuss overweight with parents?

- What characteristics affect a systematic approach to and the application of the overweight protocol?

- Does organizational support affect the CHC practitioners' performance regarding overweight prevention?

- To what extent do personal characteristics of $\mathrm{CHC}$ practitioners (profession, working in an area with low or high socioeconomic status [SES], work experience, age, the practitioner's own body mass index [BMI] and organizational aspects affect the issues of awareness, discussing overweight, systematic approach and implementing the protocol? 


\section{METHODS}

A quantitative study was conducted amongst practitioners from four $\mathrm{CHC}$ organizations: three organizations in the southern part of the Netherlands and one organization covering the central and northern parts of the country. The catchment area of the northern organization is divided into six different regions. All CHC practitioners (both physicians and nurses) work with children in the age category from birth until four years old.

From a total of $320 \mathrm{CHC}$ practitioners from these four organizations $232 \mathrm{CHC}$ practitioners participated in this study. All $105 \mathrm{CHC}$ practitioners from the southern organizations were included, while a random sample of $127 \mathrm{CHC}$ practitioners from the organizations in the center and north of the Netherlands were included.

Data collection took place in the period from February to April 2009. The participating practitioners completed a questionnaire during a meeting within their organization. Practitioners who were not present at this meeting were invited to complete the questionnaire afterwards, and return it by e-mail or post.

\section{Questionnaire}

A self-report questionnaire was developed for this study, based on the literature and results of in-depth interviews with $\mathrm{CHC}$ practitioners (Dera-de Bie et al., 2012; De Vries \& Mudde, 1998; Harmsen et al., 2005; Paulussen et al., 2007).

The questionnaire consisted of 105 items divided into five main categories: (1) awareness of the importance of prevention; (2) discussing overweight with parents; (3) adherence to a systematic approach to implement the overweight protocol; (4) supportive factors within the organization and (5) personal characteristics. The first four of these main categories give an answer to the first research question, while the final category gives an answer to the second research question. The first four main categories used a 5-point Likert scale, with options ranging from 'strongly disagree' (code 1) to 'strongly agree' (code 5) and from 'absolutely unimportant' (code 1) to 'very important' (code 5). Item response indicated that the questionnaire had a good fit, with Cronbach's alpha 0.88 . The questionnaire was pilot-tested by 9 experts in the field of $\mathrm{CHC}$ or experts on overweight, and was designed to be completed in 20 minutes.

\section{Data Analysis}

The questionnaire was inspected for completeness, and incorrect data input was checked on a random sample of 10 questionnaires ( $n=10$, incorrect input $<1 \%$ ). Data was analyzed using SPSS (Statistical Package for the Social Sciences) version 19.0 (Field, 2009). The first four main categories of the questionnaire were analyzed descriptively (mean) and items were clustered into the main categories (table 2), with the scores 1 and 2 and 4 and 5 of the 5 -point Likert scale collapsed. We used this division in scores 
instead of the mean and standard deviation to make the differences in extreme scores more visible. This descriptive analyses was used to answer the first research question. In order to answer the second research question two different statistical tests were used to identify relations with the first four main categories. First, a Mann-Whitney test for two independent samples was used to assess whether there was a difference between the first four main categories of the questionnaire and the types of profession (e.g. physician or nurse) and practitioners working in a low- or high-SES area. Also, a MannWhitney test was used to check if there were differences between the $\mathrm{CHC}$ organizations in the southern part of the Netherlands and the organizations that covers the central and northern part of the country.

Finally, Spearman's Rho was calculated to see if there was a correlation between the first four main categories and the personal characteristics of the $\mathrm{CHC}$ practitioners (working experience, age and the practitioner's own BMI).

\section{RESULTS}

\section{Respondents}

Table 1: in total, 216 of the 232 questionnaires were completed, which is an average response rate of $93 \%$. The respondents included sixty-nine physicians and 147 nurses of whom 213 women and 3 men. Traditionally, Dutch $\mathrm{CHC}$ practitioners working with children aged 0-4 years are nearly all females. The average age of the respondents was 46 years and their average number of working years was 14 . Reasons for non-completion were sick-leave, holidays or pregnancy leaves.

Table 1. Profile of participants

\begin{tabular}{|c|c|c|c|c|c|c|c|c|c|}
\hline \multirow{2}{*}{$\begin{array}{l}\text { Area } \\
\text { Organization/region }\end{array}$} & \multicolumn{6}{|c|}{ northern/central part of the Netherlands* } & \multicolumn{3}{|c|}{ southern part } \\
\hline & 1.1 & 1.2 & 1.3 & 1.4 & 1.5 & 1.6 & 2.1 & 2.2 & 2.3 \\
\hline total response & 26 & 26 & 15 & 19 & 16 & 15 & 30 & 42 & 27 \\
\hline response \% & 96 & 100 & 75 & 95 & 84 & 100 & 100 & 91 & 93 \\
\hline Physician & 10 & 5 & 6 & 5 & 5 & 5 & 9 & 16 & 8 \\
\hline Nurse & 16 & 21 & 9 & 14 & 11 & 10 & 21 & 26 & 19 \\
\hline average age & 44 & 51 & 44 & 46 & 43 & 49 & 48 & 44 & 47 \\
\hline female/male sex & $26 / 0$ & $26 / 0$ & $15 / 0$ & $19 / 0$ & $16 / 0$ & $15 / 0$ & $28 / 2$ & $41 / 1$ & $27 / 0$ \\
\hline average no. working years & 13 & 20 & 12 & 15 & 11 & 16 & 13 & 13 & 15 \\
\hline average weekly working hours & 19 & 21 & 18 & 21 & 22 & 19 & 20 & 21 & 23 \\
\hline average $\mathrm{BMI}$ & 23 & 24 & 23 & 23 & 23 & 24 & 24 & 24 & 24 \\
\hline
\end{tabular}

* Four CHC organizations participated; the catchment area of the northern organization is divided into 6 regions (1.1-1.6) and the southern part is divided into 3 regions (2.1-2.3) 


\section{Behavioral characteristics influencing overweight management in daily practice}

Table 2 summarizes the main results of the descriptive analyses, based on the first four main categories of the questionnaire. Only the most remarkable items with a cut off point of $60 \%$ or less, are described. In this table the mean of the scores of the Likert scale is presented. The total score of the Likert scale was stated as $100 \%$. Thereafter, the sum of the scale 1 and 2 as well as the sum of the scale 4 and 5 , was expressed as percentage of this $100 \%$ score. One remarkable finding is the difference between the awareness of the importance of overweight prevention. This awareness is less in children younger than one year (53.2\%) compared to children over the age of one year (90.3\%). The question on the importance of healthy feeding practices scores very high (91, $2 \%)$. By contrast, the score for the importance of physical activity in a child's first year was $56.9 \%$. The scores regarding enough knowledge about the overweight protocol scores $45,3 \%$ and $43 \%$.

Table 2 shows also that the items related to difficulty to discuss the topic of overweight scores overall less than 43,1\%. Especially discussing overweight with unmotivated parents scores low: 9.2\%. Also the experience of encountered resistance from the parent's scores just $9,7 \%$. The item related to the effective recommendation of physical activity scores $36,1 \%$.

Furthermore, the category systematic approach shows for the items "familiar with the overweight protocol" and "early detecting an overweight child", a score of respectively $27,3 \%$ and $47,7 \%$. The use of diagrams to detect overweight in children scores $36,9 \%$ while the use of an overweight protocol scores less than $46,6 \%$. Of the responders, $13.3 \%$ mentioned that it takes more consultation time. Besides $8.5 \%$ reports that they had no influence on the development of the protocol. The overall score for support from the organization was $41,2 \%$ or less. Especially, the organization fails in reminding the overweight protocol (13.6\%). Adjustment of the protocol after evaluation scores $14,2 \%$.

\section{Personal characteristics influencing overweight management in daily practice}

In table 3 the main results of the second research question, the influence of personal characteristics related to early overweight management, are summarized. There was a significant difference between the physicians and nurses as regards the main category of awareness of the protocol $(p=0.001)$. The physicians were more familiar with the protocol and possessed more knowledge that is required to apply it. In addition, the nurses reported that they had less skills to work with the protocol compared to the physicians $(p=0.004)$. There was also a significant difference in using a systematic approach. The physicians seemed to use a more systematic approach than the nurses $(p=0.005)$. 


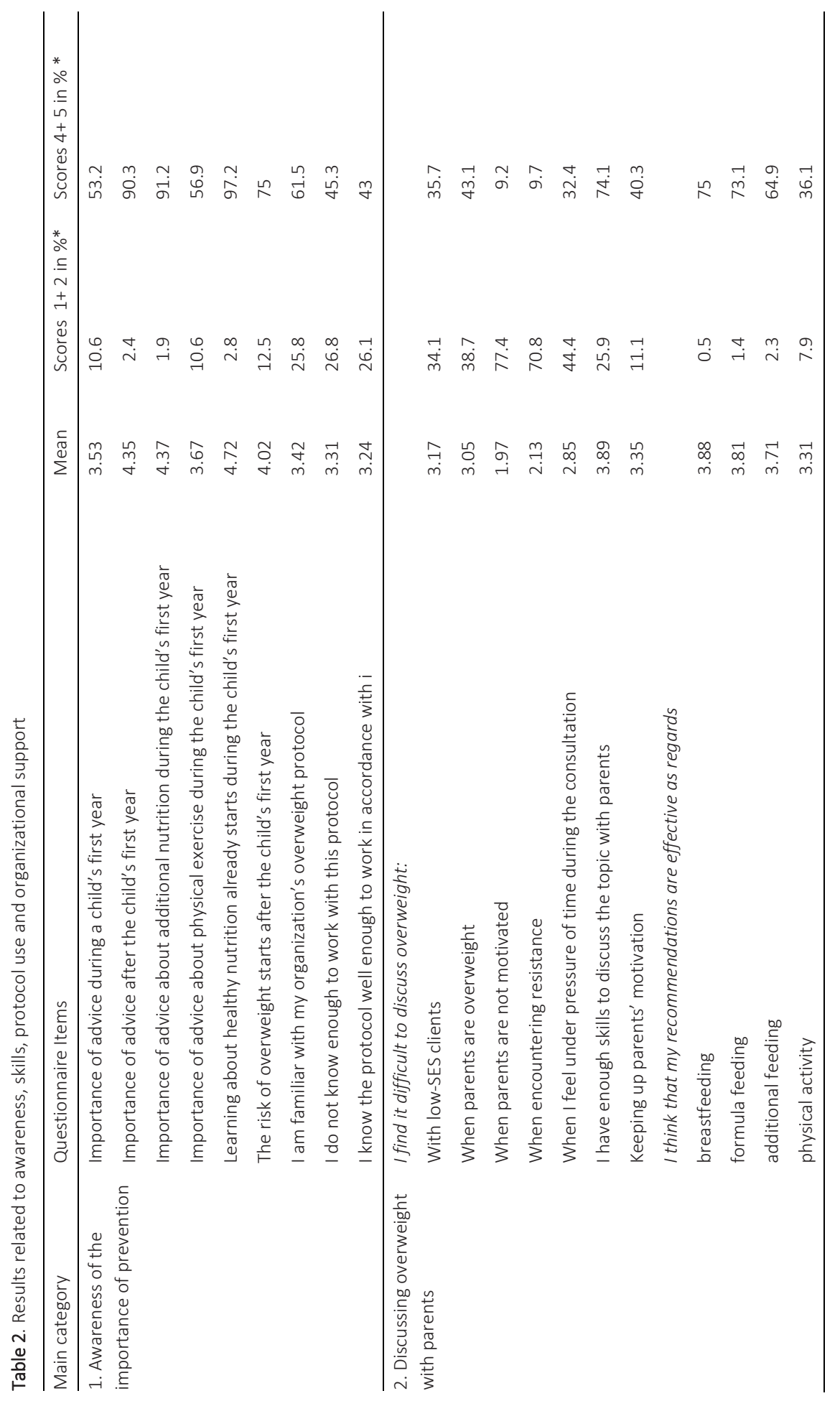




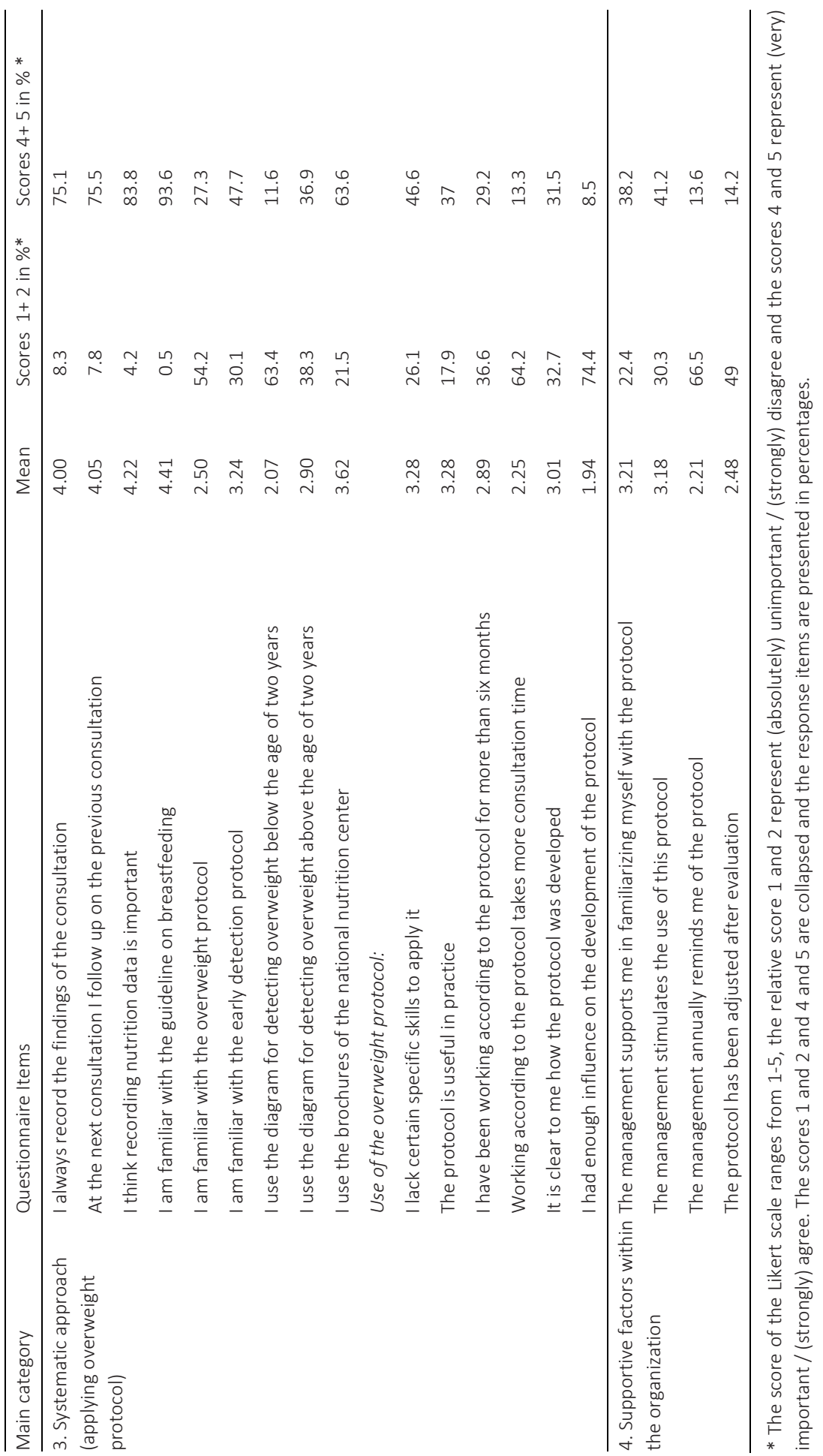


CHAPTER 3

Table 3. Results related to the second research question

\begin{tabular}{|c|c|c|c|}
\hline \multirow[t]{2}{*}{ Main category or item: Type of profession } & \multicolumn{3}{|c|}{ Mean rank score* } \\
\hline & Physician & Nurse & $p^{* *}$ \\
\hline Awareness of protocol & 98.81 & 73.58 & 0.001 \\
\hline Systematic approach & 93.75 & 72.31 & 0.005 \\
\hline \multicolumn{4}{|l|}{ (applying overweight protocol) } \\
\hline Nurses less skilled in working with protocol & 96.90 & 75.26 & 0.004 \\
\hline \multirow[t]{2}{*}{ Main category or item: SES } & \multicolumn{3}{|c|}{ Mean Rank Score* } \\
\hline & LOW SES & High SES & $p^{*}$ \\
\hline Importance of prevention of overweight in the child's first year & 44.49 & 46.23 & 0.757 \\
\hline Importance of prevention of overweight after the first year of the child & 43.56 & 48.48 & 0.360 \\
\hline I think that my recommendations about additional nutrition are effective & 42.16 & 51.88 & 0.072 \\
\hline I think that my recommendations regarding physical exercise are effective & 40,85 & 55.06 & 0.008 \\
\hline I use the materials (brochures) from the national nutrition center & 45.24 & 42.73 & 0.661 \\
\hline The guideline is useful in practice & 30.33 & 39.47 & 0.058 \\
\hline I have worked with the overweight protocol for over six months & 29.84 & 40.66 & 0.029 \\
\hline Correlations between first four main categories (Spearman's Rho) & r & & $\mathrm{p}$ \\
\hline \multicolumn{4}{|l|}{ Working experience } \\
\hline Awareness of protocols & -.017 & & 0.414 \\
\hline Systematic work approach & -.028 & & 0.36 \\
\hline Support from the organization & -.157 & & 0.028 \\
\hline \multicolumn{4}{|l|}{ Age } \\
\hline Age was associated with awareness scores & -.113 & & 0.054 \\
\hline Perceived support from the organization & -.051 & & 0.275 \\
\hline \multirow[t]{2}{*}{ Main category or item: differences between organizations } & \multicolumn{3}{|c|}{ Mean Rank Score* } \\
\hline & South & $\begin{array}{l}\text { Central } \\
\text { /North }^{1}\end{array}$ & $\mathrm{p}^{* *}$ \\
\hline Awareness related to prevention of overweight & 120.45 & 95.96 & .004 \\
\hline Use of relevant materials & 143.08 & 75.63 & .000 \\
\hline
\end{tabular}

* Mean Rank: a higher mean rank means a more positive score.

** if $Z$ score is higher than 1 . It is significant; $P<.05$

Overall, there was no difference found between practitioners working in a low-SES area and those working in a high-SES. Nevertheless, the $\mathrm{CHC}$ practitioners working in a lowSES area had significant lower scores on the effect of their recommendations regarding physical activity in the child's first year $(p=0.008)$. Moreover, practitioners working in high-SES area scored significant higher when it comes to use the overweight protocol for over six months in daily practice $(p=.0029)$. A close significant result was found regarding the issue that practitioners working in a low-SES area were less likely to answer that the overweight prevention protocol is useful in daily practice $(p=0.058)$. 
There was a close positive relation between encountering resistance when discussing the topic of overweight and working experience. The older the practitioner, the more one was aware of overweight prevention during the first year of life $(p=0.054)$. Yet, the age of the practitioner was not correlated with perceived support from the organization. Furthermore, a correlation was found between years of working experience and the category support from the organization $(p=0.028)$. The years of working experience and the category's' awareness of protocols and a systematic working approach are not correlated. Also, there was no correlation between the practitioners' own BMI and awareness, discussion skills and systematic working approach.

\section{Organization}

As regards to the main category "differences between organizations", the organizations in the southern part of the Netherlands scores higher on awareness and use of relevant materials compared to the organizations in central and northern part of the country $(\mathrm{P}=.004$ resp. $\mathrm{P}=.000)$.

\section{DISCUSSION}

A questionnaire was used to investigate which behavioral and personal characteristics' of the $\mathrm{CHC}$ physician and nurse influence overweight prevention in daily $\mathrm{CHC}$ practice.

The main results indicate that there is insufficient knowledge by $\mathrm{CHC}$ practitioners regarding the overweight protocol and skills are lacking related to discus with parents the (risk) of overweight of their child. Moreover, the $\mathrm{CHC}$ nurses seemed to be less likely to apply the overweight protocol than the $\mathrm{CHC}$ physicians. Perhaps physicians and nurses focus on different aspects of a protocol, which could be explained by their different tasks, their professional culture regarding refresher courses or their different learning styles (Goossens et al., 2008). Overall the gap in knowledge and skills can hamper the application of protocols in practice.

Striking is the fact that the practitioners' attitude towards the implementation of the prevention measures and the intention to make use of the protocols were positive. Generally speaking, the underlying problem may be one of insufficient attention to protocol implementation, especially regarding the continuation. This is in agreement with the results of the study by Fleuren \& De Jong (2006), who found a nationwide lack of implementation culture within the Dutch $\mathrm{CHC}$, despite the fact that there is a growing attention since 2006 from the national $\mathrm{CHC}$ to the regional ones in supporting protocol implementation. The protocol implementation structure plan has been developed at national level (Dunnink, 2013). Yet, specific information on local issues is important for the development and implementation of a childhood overweight management action plan (Brink-Melis et al., 2012). 
The $\mathrm{CHC}$ practitioners we surveyed agreed with the importance of overweight prevention, but their focus was clearly less on the children's first year. Although the scores they gave for the importance of healthy nutrition were high, it seemed that the practitioners did not relate this to the importance of early overweight prevention. They also underestimated the importance of physical activity, especially in the child's first year (Kohl et al., 2012).

Furthermore, discussing the issue of overweight with parents is experienced as difficult with unmotivated parents and parents who show resistance. It might therefore be useful to train practitioners in risk communication and motivational interviewing techniques (Schwartz et al., 2007). This is a method to encourage unmotivated parents to make healthy choices regarding their lifestyle and therefore also for that of their children.

This is in line with the model by Paulussen, which shows that characteristics of the users play a key part in effective behavioral change interventions (Paulussen, 2007). Especially knowledge, which influences the attitude, can be improved. Also, this can be explained from the ASE model, by assuming that a more positive attitude of all parents to prevent overweight for their child can be improved and this influences directly also the intention of parents to go for a healthy lifestyle (De Vries \& Mudde, 1998).

Overall, organizational support was often reported to be lacking. Yet, it is likely that CHC practitioners more working experience are more familiar with the overweight protocol and have more routine experience. However, more support from the organization for the implementation of early prevention measures may improve prevention (i.e. protocol application) in routine $\mathrm{CHC}$ practice. Constraints such as lack of time and training (for knowledge and skills) impede the implementation. These barriers have also been identified in previous research (Story et al., 2002).

The results of this study also suggest that $\mathrm{CHC}$ practitioners who are working in lowSES areas are less likely to apply the overweight protocol, possibly because low-income families are less health-conscious, making it more difficult to advise or motivate these parents with regard to healthy nutrition or physical exercise (Schefske et al., 2010). At the same time, research has shown that child growth is greatly influenced by SES status, and that the problem of overweight is greater among low-income families, making extra support by CHC practitioners more necessary (Graitcer \& Gentry, 1981).

A strength of this study is that the response rate was remarkably high, which might be caused the fact that there was direct contact with the respondents. This study was performed among $\mathrm{CHC}$ practitioners working for four $\mathrm{CHC}$ organizations in different regions of the Netherlands, to achieve a better representativeness of our sample fort the Netherlands as a whole. The slight differences between the south and the northern and central part of the Netherlands are explainable, because the overweight protocol was earlier implemented in the south part of the Netherlands. Since we found hardly any differences between the organizations, these findings may be broadly transferable to the national level of child care. 


\section{Implications}

A number of recommendations emerge from this study. Changing $\mathrm{CHC}$ practitioners' attitudes and behavior towards early overweight management and protocol application will require more support in terms of improving their knowledge and skills. It is especially the CHC practitioners working in low-SES areas who should receive more support from their organization, as they indicated that they expected less impact from the use of the overweight protocol, and as the problem of overweight is known to be greatest in these areas. Further research is necessary to provide practitioners with essential information about education methods and materials specifically aimed at this low-SES group.

Furthermore, it seems important not only to motivate parents to achieve a healthier lifestyle, but also to set systematic long-term goals for empowering and supporting parents in order to help them actually achieve healthier behavior. Behavioral change cannot be achieved in a single consultation, but could be achieved by repeatedly discussing this theme. This would appear to be a task for the nurses rather than for the physicians, in view of the educational aspects involved. Clear allocation of tasks and sufficient training of competencies and skills to discuss (the risk of) overweight with parents is essential for effective prevention. Another good opportunity to discuss prevention of overweight with parents is when the babies start additional nutrition. In fact, overweight prevention starts in pregnancy, and it should be a recurring theme in the $\mathrm{CHC}$ program. During the first consultation in the $\mathrm{CHC}$ program, practitioners can ask parents about lifestyle risk factors for overweight, such as their own weight. This, because it is known that overweight is a part of the family system.

Also, since the CHC monitors children's growth and development, and there are about eight consultations during the child's first year, an effective and practical instrument to detect a child at risk for overweight already in the child's first year may help $\mathrm{CHC}$ practitioners discuss overweight prevention with parents.

\section{CONCLUSION}

We may conclude that there is a need to improve the prevention of overweight among very young children, even those who not yet overweight. A great deal of health can be gained if prevention of overweight starts already it in the child's first year.

Training of skills to discuss the problem of overweight with parents is needed, especially with unmotivated parents and parents who resist such attempts. This seems especially true for $\mathrm{CHC}$ nurses who work in low-SES areas. Furthermore, a more systematically an effective implementation strategy as well as sufficient follow-up and essential preconditions, such as risk communication skills and a clear monitoring instrument could influence a better protocol use in daily $\mathrm{CHC}$ practice. This may result in a better preventive overweight management in $\mathrm{CHC}$ settings. 



\section{CHAPTER 4}

\section{Training program for overweight prevention in the child's first year: \\ compilation and results}




\section{ABSTRACT}

The current local overweight protocols are not applied as intended by Dutch child health care physicians and nurses. This article describes the development of a training program for these practitioners, based on the Intervention Mapping framework, with the aim of improving overweight prevention in a child's first year. The needs assessment showed three program objectives to be relevant, namely improving (i) awareness of the importance of early overweight prevention, (ii) the competence to discuss overweight (or the risk of overweight) with parents and (iii) working systematically according to the overweight protocol. A matrix was then created specifying the program objectives in terms of personal learning objectives and environmental change objectives, and appropriate strategies were identified. The main strategy consisted of repetition of information and frequently practicing communication skills. The results suggest that a more active tailored and structured change strategy improves especially knowledge and skills which results in a better overall implementation of the local overweight protocol and actual use in daily practice. This training program should help to understand how the implementation of a protocol, such as the overweight protocol, can be improved. Using the Intervention Mapping framework for systematic protocol implementation seems a valuable option.

Keywords: overweight, prevention, training program, practitioner and intervention mapping. 


\section{INTRODUCTION}

Overweight in children is recognized as a major public health concern because of the associated lifelong health consequences, such as metabolic syndrome or cardiovascular diseases (L'Allemand-Jander, 2010; Reilly \& Kelly, 2011; WHO, 2000). In addition, there is evidence that a child's first year is an important period for the prevention of overweight (Barker, 2007; Gluckman \& Hanson, 2004). It is in this first year that the foundations are laid for lifestyle behaviors that may track throughout children's lives and can impact on adult weight (Singh et al., 2008). It is thus clear that overweight prevention programs in this early period are important and that they should focus on the parents, as they are the ones who lay the foundations for their child's healthy lifestyle (Kelder et al., 1994).

In the Netherlands there is a system, known as child health care (CHC) that supports parents by providing a free of charge nationwide program of regular preventive health checks. The CHC service monitors the growth and development of more than $95 \%$ of Dutch children from birth to the age of 19. In view of the increasing prevalence of overweight among children, $\mathrm{CHC}$ has developed national overweight prevention guidelines to address this problem (Dunnink \& Lijs-Spek, 2008). These guidelines focus on (i) monitoring the growth of the child and early detection of abnormal growth patterns, (ii) identifying overweight children, (iii) preventing overweight, (iv) advice about nutrition for children aged 0- 4 years, and (v) supporting breastfeeding. At local level, CHC services translate these guidelines into their own organizational protocols. However, the success of such a protocol depends on its implementation (Grol, 2001). A numbers of barriers, such as lack of knowledge, skills, time and organizational support can hamper the proper implementation of protocols (Campbell et al., 2000; Fleuren et al., 2004).

The results of several studies have shown that there is a need to investigate what can be improved, after which a systematic and well-planned training program is needed to improve protocol implementation in practice (Brug et al., 2005; Haines \& Donald, 1998). The training program should address the main barriers relating to $\mathrm{CHC}$ practitioners' behavior and the necessary preconditions that can be created by the organization.

To develop such a training program, we used the systematic Intervention Mapping (IM, figure I) approach for program development (Bartholomew, 2006). The present article introduces the IM approach, describes in detail the steps needed to develop such a training program and its results.

\section{Intervention Mapping}

IM provides a framework, based on a combination of theoretical evidence and practical information, which can be used to structure the development of a training program for $\mathrm{CHC}$ practitioners (e.g. physicians and nurses). IM is a stepwise approach, each leading to a product that guides the next step. Prior to the IM approach it is essential to con- 
duct the need for a training program and define the content of such a program, in order to address the most important barriers experienced by $\mathrm{CHC}$ practitioners and the relevant and changeable behavioral determinants prevalent among them. It then specified the training goals, which are subdivided into personal and environmental change objectives and related determinants. Subsequently, theoretical methods are selected to change the behavioral determinants and these are translated into practical strategies that can be used in the training program. This results in the creation of a matrix which can be regarded as the design of the actual training program (table I). The aim of our training program is to achieve satisfactory implementation of the Dutch overweight protocols for children aged 0-1 year.

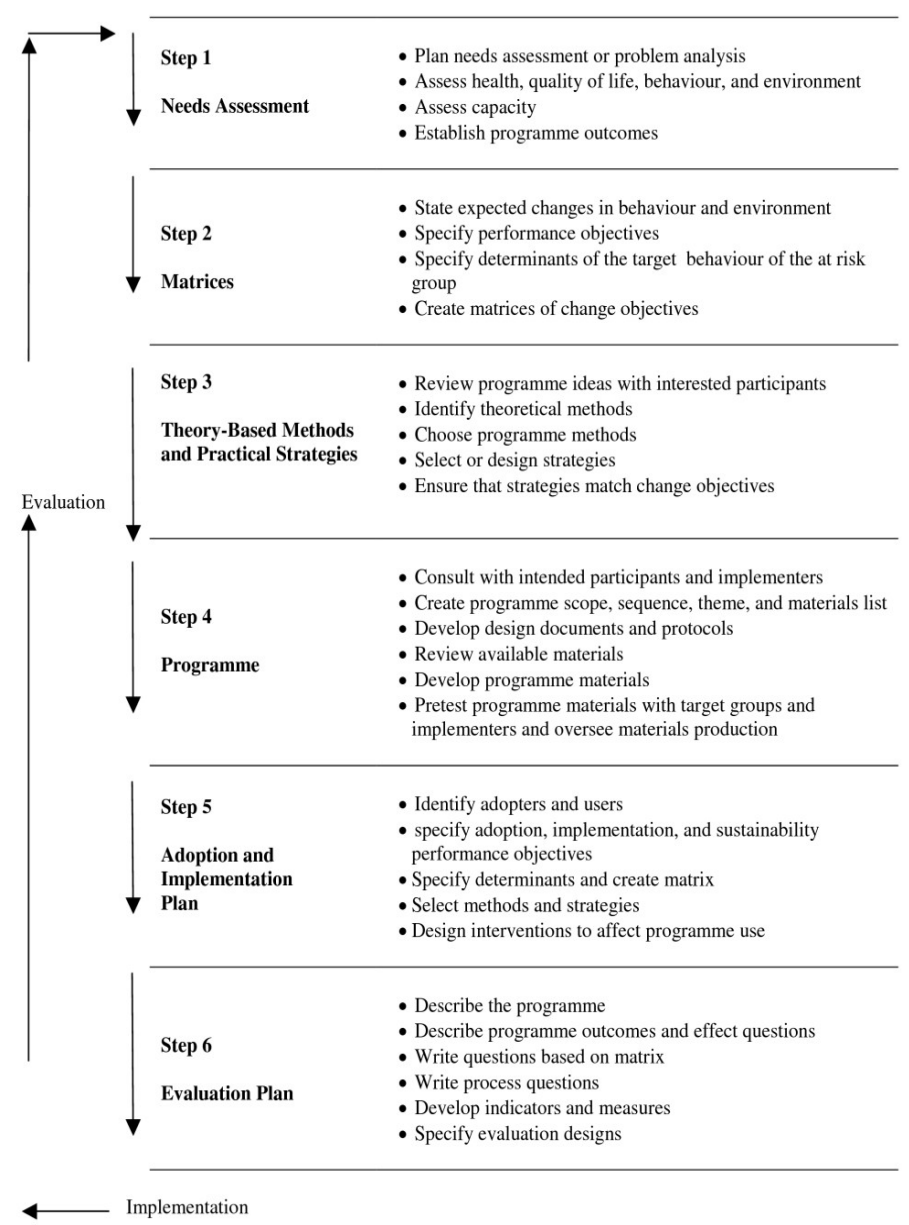

Figure 1. Intervention Mapping protocol (Bartholomew et al, 2006) 


\section{DEVELOPMENT OF THE TRAINING PROGRAM}

\section{Needs assessment}

The need for a training program was explored in a qualitative study. Twelve CHC physicians and nurses were interviewed about their current practice as regards overweight prevention in children's first year and the barriers they encountered regarding protocol implementation. Then a self-report questionnaire was developed to investigate the barriers encountered, both in terms of personal behavior and preconditions created by the organization employing them.

Four $\mathrm{CHC}$ organizations were approached with the request to present the questionnaire to their practitioners. Out of a total of $232 \mathrm{CHC}$ practitioners, 219 filled out the questionnaire. The findings from the interviews and the questionnaire identified three major barriers (Dera et al., 2012). The first is a lack of awareness among CHC practitioners that a child's first year is an essential period for the prevention of overweight as a result of which they do not regard early detection of children at risk for overweight as important in this period. It is also not clear to them when a given weight in the child's first year implies an increased risk for developing overweight. This might affect their ability to identify children at risk. Secondly, $\mathrm{CHC}$ practitioners find it difficult to discuss overweight with parents, especially when they experience resistance from these parents. Thirdly, the practitioners do not always sufficiently adhere to a systematic working approach, and this influences the implementation of the overweight protocol as intended. For example, the results of history-taking and the advice given are not properly recorded, and referral paths and additional materials are often not used as intended (Arentsen et al., 2009).

In sum, the lack of awareness, the difficulty of discussing overweight, and the lack of systematic working methods result in inadequate implementation of the overweight protocols. In order to tackle these three barriers, we constructed a matrix to serve as the foundation for the training program, following the IM approach. The creation of this matrix involves several steps, as outlined below.

\section{Step 1 Defining program objectives}

Based on our needs exploration, we chose the following objectives for the development of the training program: (i) CHC practitioners must be aware that growth and the development of lifestyle behaviors in a child's first year will affect their weight during the rest of their lives, so that early prevention of overweight is important; (ii) CHC practitioners must be able to discuss overweight (or at risk for overweight) with parents; and (iii) $\mathrm{CHC}$ practitioners must work systematically according to the organization's overweight prevention protocol. 


\section{Performance objectives and determinants}

Attaining these three training objectives requires specification of what the $\mathrm{CHC}$ practitioner has to learn in order to attain them, and what has to be changed in their working environment, i.e., the organization. To this end, the training program should distinguish between personal learning objectives (LO) and environmental change objectives (CO).

As regards the learning objectives, (i) awareness can be promoted by new knowledge that positively influences attitudes. Relevant determinants to reduce the (ii) difficulty of discussing overweight are knowledge, skills, self-efficacy and outcome expectations. The same determinants are relevant for (iii) working systematically to implement the protocol (LO). Regarding the environmental change objectives, social support and barriers within the organization were identified as the most important determinants.

\section{Step 2 Selection of theoretical methods and practical strategies}

For each determinant, we identified appropriate theories and change methods from the literature. The relevant theories we selected for the training program were primarily adapted from Bandura's Social Cognitive Theory, Weinstein's Precaution Adaptation Process Model, the Elaboration Likelihood model, and the model developed by Fleuren and Paulussen (Bandura, 1986, 2004; Bartholomew et al., 2006; Fleuren et al., 2004).

The needs assessment showed that it was especially knowledge and skills regarding communication techniques that were lacking. In order to change these determinants, we focused on two overall strategies, viz. repetition of information and frequent and consistent practice of communication skills. Changing the level of a person's knowledge and skills takes a certain amount of time before a new behavior is generated, so we opted for an annual schedule with regular training activities to change these determinants.

Knowledge transfer can be supported by information provided by experts, interactive group discussions between $\mathrm{CHC}$ practitioners, guided practice and feedback. These activities stimulate the process of active learning and help to tailor relevant messages to the CHC practitioners' routine practice (Bartholomew et al., 2006; Petty \& Cacioppo, 1986). Moreover, knowledge is a precondition for changing a practitioner's attitude in terms of awareness of the risk of overweight in infants (Bandura, 1986; Weinstein et al., 2002). CHC practitioners should be aware that a chubby child or a child with an abnormal growth pattern in the first year can be at risk for overweight.

As a technique to address the lack of communication skills, we opted for Motivational Interviewing (MI), because motivating parents is one of the most important determinants of treatment success (Fransen et al., 2008; Miller \& Rollnick, 2002). In addition, the topic of "overweight" is emotionally charged, because of the sense of personal responsibility among parents and their experience of "failure" in raising their child, their experience of their own weight or the feeling of stigmatization and negative attitudes 
associated with the topic in Western societies, in terms of "blaming the victim". Successful communication is a prerequisite for the consultations between $\mathrm{CHC}$ practitioners and parents, which aim to change the parents' perceptions regarding their child's risk of developing overweight and related factors such as the food behavior or limited physical activity (Eckstein et al., 2006; Jansen \& Brug, 2006). MI, interactive group discussion, guided practice and feedback are strategies that can be expected to influence knowledge, skills, self-efficacy, and outcome expectations (Bartholomew et al., 2006). Self-efficacy and outcome expectations refer to a CHC practitioner's perception of their competence and their confidence to discuss the risk of overweight with parents. Lack of confidence in parents' adherence to $\mathrm{CHC}$ advice inhibits the $\mathrm{CHC}$ professional in giving advice. Routine questions at the first consultation about the parents' height and weight, their BMI and lifestyle, and raising the child in a healthy way can contribute to normalizing the discussion about weight and overweight.

A systematic working approach can be achieved if $\mathrm{CHC}$ practitioners possess the relevant knowledge about the existence and content of the overweight protocol. Repeated promotion of the protocol by various sources, such as the organization's newsletter, giving attention to the topic during organization's meetings, opportunities to ask questions online, and observations of individual $\mathrm{CHC}$ practitioners' performance during consultations with feedback, can increase not only the practitioners' knowledge, but also their skills, self-efficacy and outcome expectations (Bartholomew et al., 2006).

In addition, practitioners should be shown "how to use" the overweight protocol in practice, which could be accomplished by interactive group discussions and individual observation sessions during consultations. This encourages $\mathrm{CHC}$ practitioners to reflect on their own and each other's work, as they gain more insight into their own blind spots and routines. This also results in more agreement and uniformity about "what" and "how" to record in the electronic child records.

As regards the environmental change objectives, the implementation of the local overweight protocol by $\mathrm{CHC}$ practitioners can be improved by social support from the management and by the removal of barriers, e.g. by allowing sufficient time for extra consultations. These strategies are expected to contribute to an active self-learning culture within the organization, and encourage $\mathrm{CHC}$ practitioners to practice their skills repeatedly.

Another way to contribute to the implementation of the overweight protocol in practice is to prioritize the topic on the organizational agenda and embed the training components into the organization's plan - do - check - act cycle (PDCA) (Alemi et al., 2000). For example, recording of risk factors, advice, and referral in electronic child records should be obligatory and monitored by the management. Feasibility barriers such as time constraints can be influenced by improving practitioners' skills to structure consultations, as this result in faster problem analysis. Positive reinforcement by management will also boost CHC practitioners' motivation. The specification of steps 1 and 2 
resulted in a matrix (Table 1), which served as the basis for designing the training program.

\section{Step 3 Designing the training program}

The training program we designed consists of 8 components: (i) a kick-off meeting, (ii) an expert meeting, (iii) a skills training course for the Ml technique, (iv) interactive group meetings, (v) observations of individual practitioners' performance by a trainer, (vi) newsletters, (vii) related articles, and (viii) opportunities to ask questions by mail or telephone.

The training program starts with a kick-off meeting with managers and $\mathrm{CHC}$ practitioners to inform them about the training program. At the next meeting, an expert provides information about the topic and special attention was given to the subject growth in the child's first year. This is followed by a two-day session to train the CHC practitioners' skills in applying the $\mathrm{Ml}$ technique. Regular interactive group meetings already exist for $\mathrm{CHC}$ physicians, but not for $\mathrm{CHC}$ nurses and they have now been introduced in the program for nurses as well. The topic of prevention of overweight was put on the agenda of these interactive group meetings. Regarding the group discussions, all CHC practitioners had to write a case story by systematically describing the problem, its analysis and proposed interventions.

The training program also includes two observation sessions to assess the individual CHC practitioners' performance. A special assessment form was developed for this purpose, addressing history-taking, recording, consultation structure, knowledge, verbal and non-verbal communication techniques, and questions for parents. This procedure is a normal method in the Dutch health care system to assess the quality of someone's performance and identify opportunities for improvement. The regular interactive group meetings with colleagues, individual observation sessions and feedback related to the daily work in $\mathrm{CHC}$ practice is intended to create new routines among $\mathrm{CHC}$ practitioners.

\section{Step 4 Adoption and implementation}

The intended participants of the training program are all $\mathrm{CHC}$ physicians and nurses of the $\mathrm{CHC}$ services in the southern part of the Netherlands (Maastricht region). If the $\mathrm{CHC}$ practitioners are to adopt the overweight protocol, they must perceive benefits of the new working method, and the training program must fit in with their daily work flow.

As part of the training program, a manual has been produced offering instructions and new materials were developed such as a flowchart showing the items to be recorded in the electronic child records. To stimulate the adoption of the new working methods in routine practice, the training components are embedded in the $\mathrm{CHC}$ organizations' regular training course structure. A supervisor is responsible for ensuring that training components are embedded in the organizational PDCA cycle. 


\section{Step 5 Evaluation}

The training program has been evaluated in terms of process and effect evaluation. The process evaluation is based on a logbook that has been served as a guide through the training. This logbook includes evaluation of the content and organization of the training program. From the evaluation of the $\mathrm{Ml}$ training practitioners mentioned that there is even more need for skills training in discussing difficult subjects with parents. In addition, the interactive group discussions and individual observations are experienced by the $\mathrm{CHC}$ practitioner as very useful training components in order to gain more knowledge and training skills.

Regarding the effect evaluation, a quasi-experimental design with intervention and control group was used to assess the effectiveness of the training program. A self- report questionnaire has been completed at baseline and follow up (one year). This questionnaire consisted out of 105 items on 5-point Likert scale and background information about the $\mathrm{CHC}$ practitioner. Off a total of $105 \mathrm{CHC}$ practitioners, 61 filled in the questionnaire (table 2). Reasons for dropout after the first baseline measure are retirement of practitioners, natural course, sick-leave, holiday or pregnancy.

Table 2. Profile of the participants

Characteristics of $\mathrm{CHC}$ Physicians and Nurses

\begin{tabular}{llll}
\hline Area & $\begin{array}{l}\text { Maastricht } \\
\text { Intervention group }\end{array}$ & $\begin{array}{l}\text { Heerlen } \\
\text { Control group }\end{array}$ & $\begin{array}{l}\text { Sittard-Geleen } \\
\text { Control group }\end{array}$ \\
\hline Total practitioners /characteristics & 33 & 44 & 29 \\
Response & $\mathrm{N}=21(63 \%)$ & $\mathrm{N}=26(59 \%)$ & $\mathrm{N}=14(48 \%)$ \\
Profession* & 7 & 11 & 6 \\
CHC Physician & 14 & 15 & 8 \\
CHC Nurse & 18 & 25 & 14 \\
Female* & 3 & 1 & 0 \\
Male & 51 (SD41-61) & $46($ SD35-66) & 48 (SD34-60) \\
Mean Age & 14,2 & 10,9 & 13 \\
Years of Profession & 18,7 & 20,8 & 22,2 \\
Average working hours & & & 6 \\
\hline
\end{tabular}

* These are $\mathrm{CHC}$ physicians or nurses, specialized in early growth and development of children aged 0-4 years.

** From a total of 105 practitioners working in the CHC Services in the Southern Limburg district 101 are female and 4 are male.

From tradition the practitioners in the Netherlands working for $\mathrm{CHC}$ organizations with children aged 0-4 years are almost all female.

For each item on the 5-point Likert scale the answers are computed so that follow up answers are subtracted from the answers at baseline. Additionally, for each individual question a paired-sample t-test has been performed. The main outcome shows that 
there is a more positively increase by the intervention group than the control group, regarding (i) the awareness of the importance of prevention, especially for the child's first year, (ii) knowledge about protocols, which seems also to affect a more systematically working approach and a better use of relevant materials in practice and (iii) less difficulty with respect to discus the topic overweight with parents (table 3). Moreover, $\mathrm{CHC}$ practitioners from the intervention group mentioned that the overweight protocol is more embedded in the organizational PDCA compared to the control group.

In summary the training has an impact on the three program objectives in a positive way. The hypotheses, that a more active training strategy will favorably influence the behavior of the $\mathrm{CHC}$ practitioners in terms of improving the implementation of the overweight protocol seems to be confirmed (Alemi et al., 2000). 


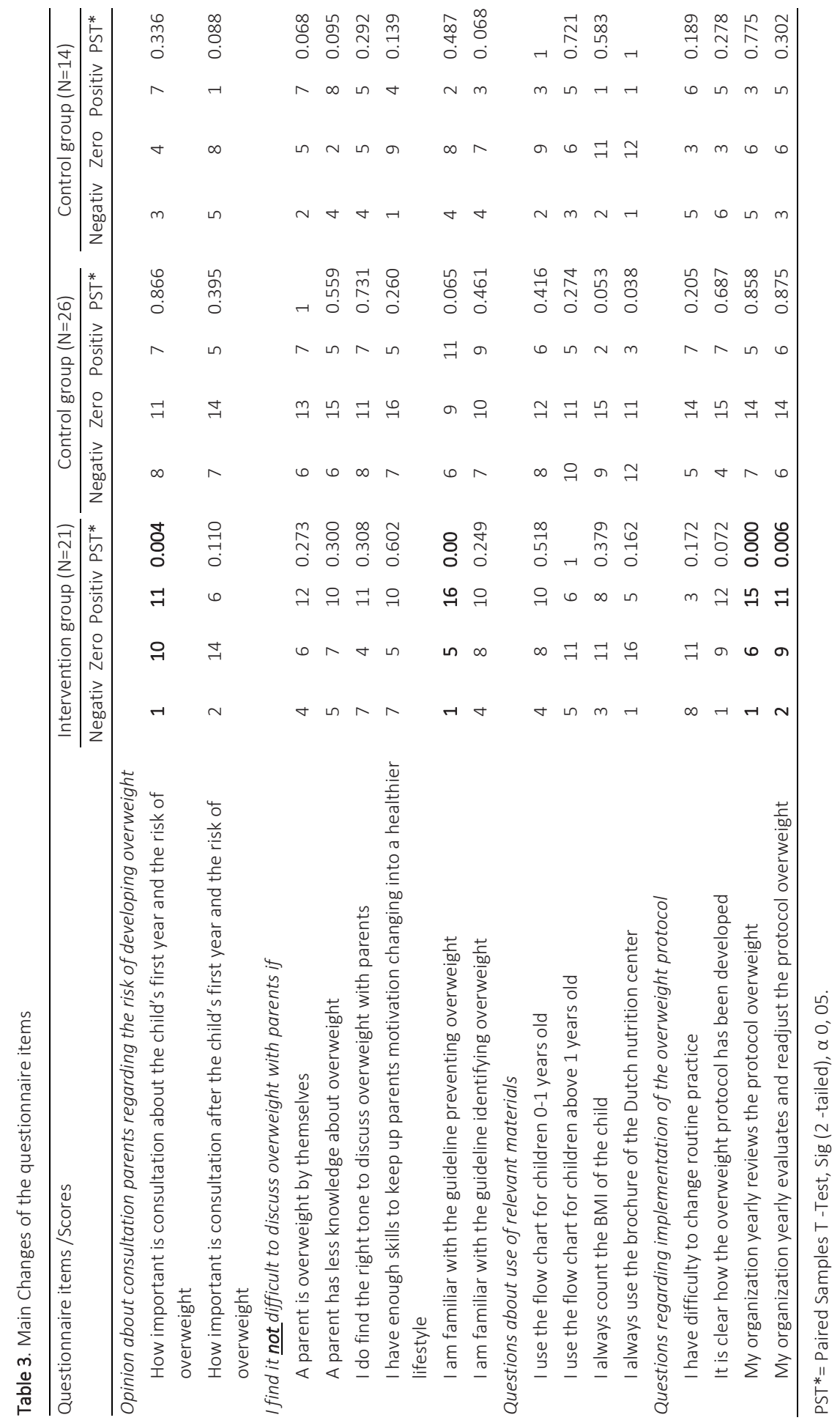




\section{DISCUSSION}

The aim of our study was to develop a tailored training program for $\mathrm{CHC}$ practitioners focusing on children's first year of life, in order to improve the implementation of overweight protocols. So far, only a few studies have addressed the barriers encountered by health care practitioners in the implementation of early overweight prevention. Even fewer studies have addressed the problem of "how to change" or address the perceived barriers in practice in order to manage early overweight prevention.

The concept of Information Mapping (IM) provides a theory-based and practical aid for the development, implementation, adaptation, and evaluation of training programs to support protocol use in daily practice (Bartholomew et al., 2006). The combination of existing theories and an exploration of routine practice could improve the implementation of protocols. Too often, protocols are designed and implemented without considering how they can be efficiently integrated in everyday practice. The literature shows that a structural and systematic approach is more successful, and the creation of a matrix as part of the IM method provides a clear overview of program components and makes the program more transparent.

The process of IM is iterative and cyclic rather than linear. In our situation, it promotes a training program matching the needs of $\mathrm{CHC}$ practitioners and makes it possible to adapt to changes in practice. The development of this training program, following the IM procedure, is transferrable to other $\mathrm{CHC}$ services. It may be also interesting for other health care settings, under the condition that it is tailored to the needs of the target population, i.e., health care practitioners.

Although IM is a time-consuming process, it forces designers at an early stage to reflect on feasibility and continuation of the program, and provides a useful checklist to relatively quickly tailor an existing protocol. To reduce time investment, we used previously developed activities and materials. This also helped us avoid "reinventing the wheel", which would have used up even more resources and time. The format of the training program we developed allows $\mathrm{CHC}$ practitioners to introduce cases and questions as part of their training that are closely related to their practice, which supports them in getting familiar with the protocol.

The IM protocol states that it is not only the environment which must change, but also the behavior of the $\mathrm{CHC}$ practitioner themselves. Actually, the relation between $\mathrm{CHC}$ practitioners and parents is currently changing from a rather paternalistic one to one of collaborative partnership. In addition, healthcare organizations are currently supporting a self-management approach for chronic diseases such as overweight. This requires the $\mathrm{CHC}$ practitioners to develop different skills and competences relating to communication techniques. These skills can also be used for other $\mathrm{CHC}$ health issues, such as asthma or eczema (Cabana et al., 2006). Without the necessary knowledge and skills, a CHC practitioner may not be able to effectively counsel parents about appropriate healthy lifestyle behaviors. We took this into account when we translated the pro- 
gram objectives into performance objectives, learning and change objectives. Yet, it is important that the organization for which a $\mathrm{CHC}$ practitioner works supports the implementation of the overweight protocol, by creating the necessary preconditions and removing barriers.

However, the training program has some limitations. It is difficult to control external conditions that influence practitioner's practice, such as $\mathrm{CHC}$ policy changes or the development of fast-food baby products. An affordable theory based training program which can be performed in daily routine practice is easier to implement and achieves improvement in management of children at risk for overweight.

Efforts to develop training programs aimed at behavioral and organizational change are known to often lack underlying theoretical approaches. Similarly, the current CHC practice lacks a systematic approach and there is an overload of new protocols being implemented in CHC organizations (Fleuren, 2010).

CHC practitioners value the presence of a supervisor, who should not only coordinate the implementation of the prevailing overweight protocol, but should also further optimize the protocol and its use in routine practice. Yet, it must be clear what the responsibilities and competences of the supervisor are, such as a mandate for protocol implementation and related tools.

In conclusion, IM may be a valuable tool for the development of planned training programs for protocol implementation, as it identifies barriers and necessary training components and makes protocol implementation, like the overweight protocol, more transparent for other health care practitioners. The developed training program seems to be more effective than current "care as usual" protocol implementation and it contributes to a better application of early overweight prevention in $\mathrm{CHC}$ daily practice. Also, embedding a structured tailored training program for protocol implementation into the organization's PDCA cycle may increase its effectiveness 


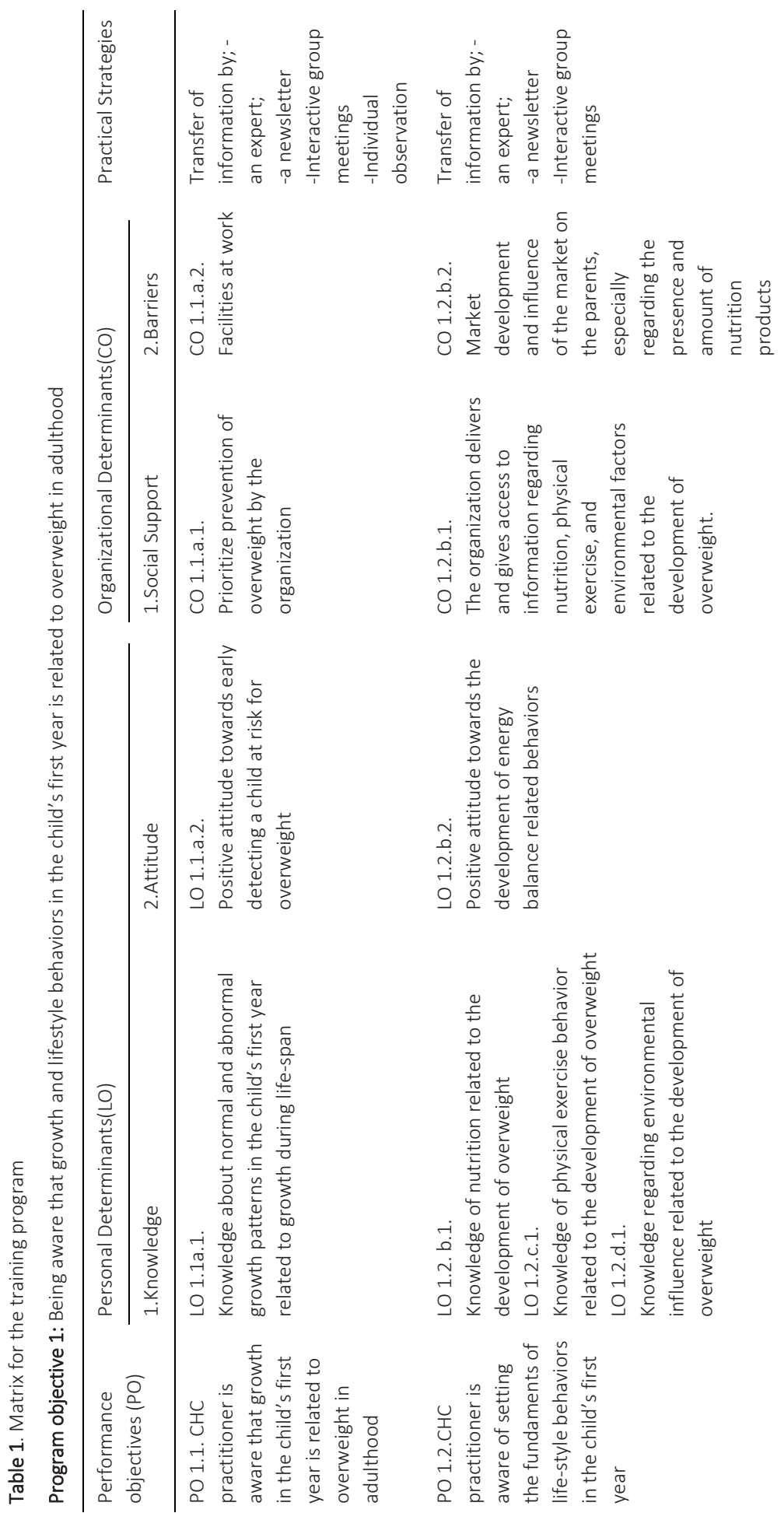




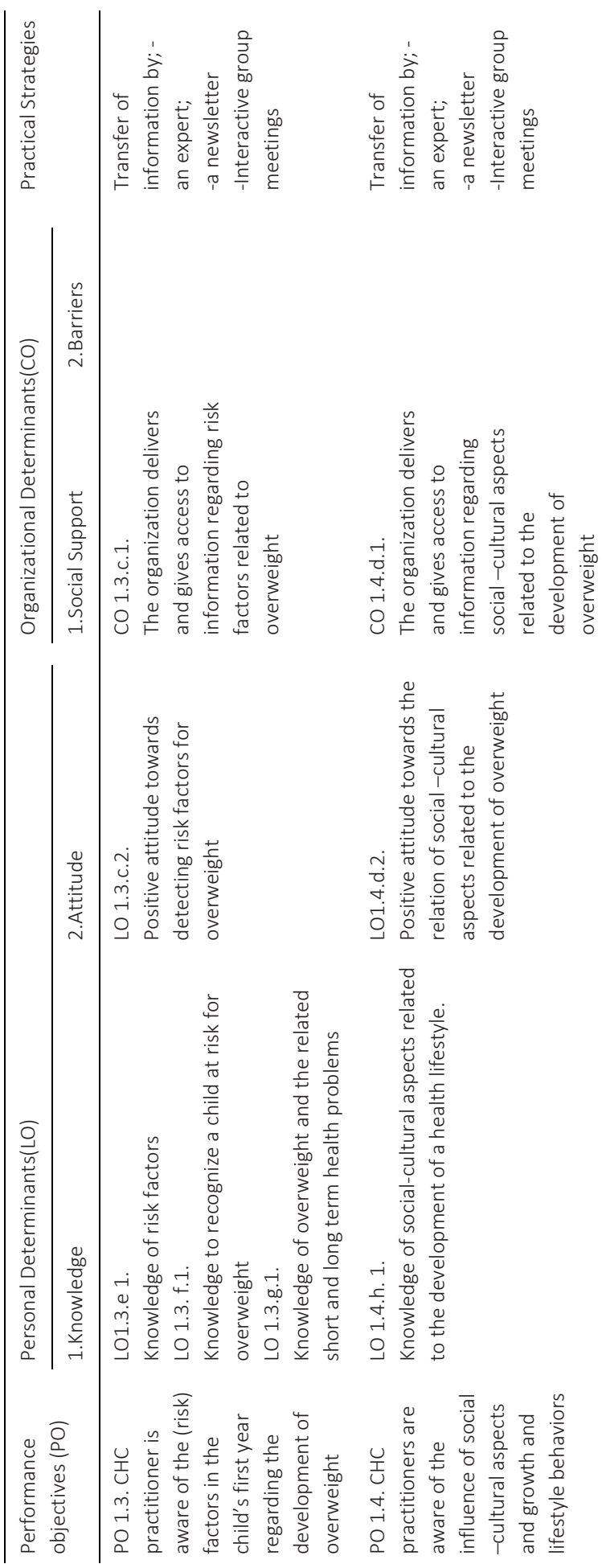




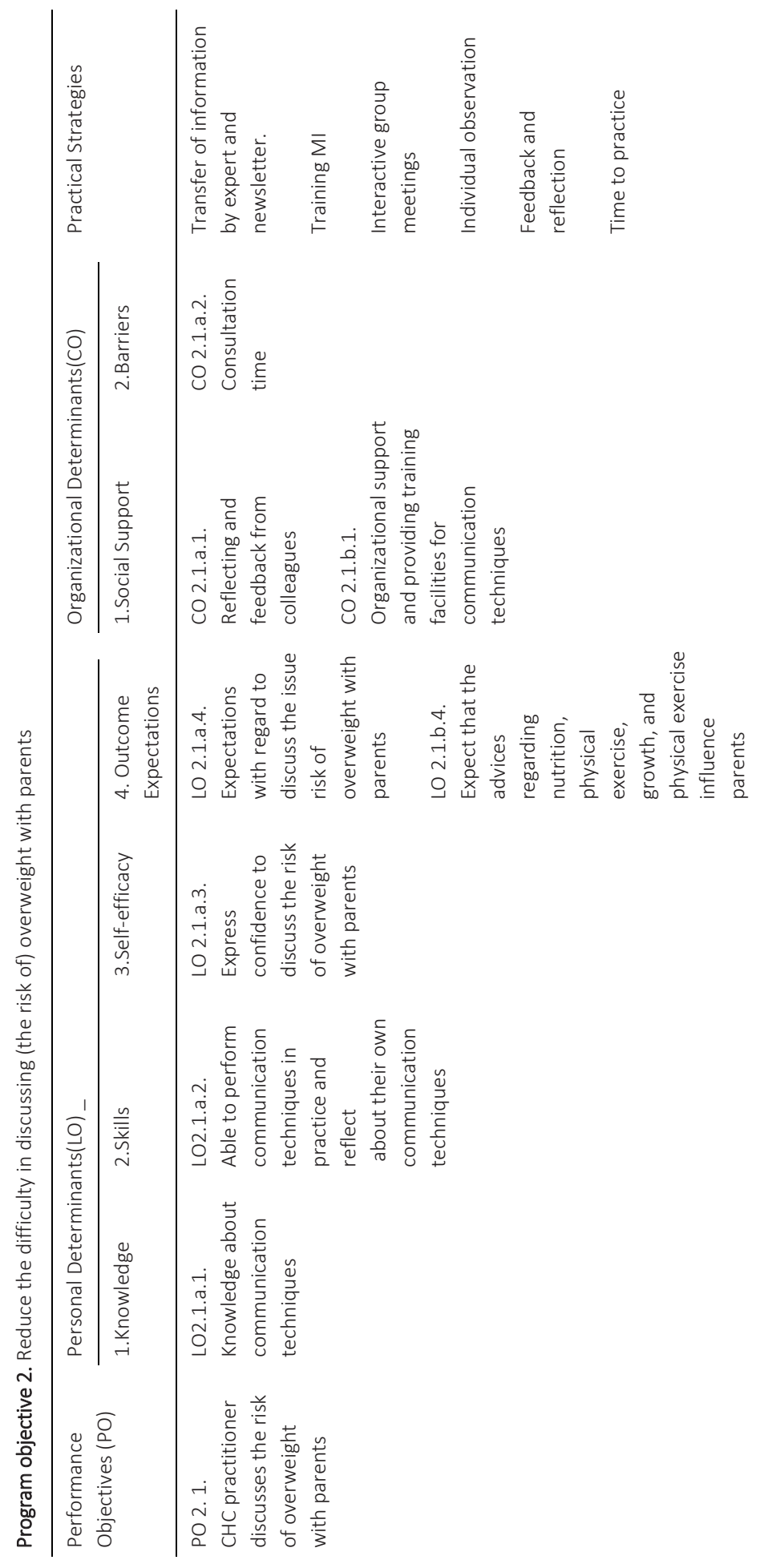




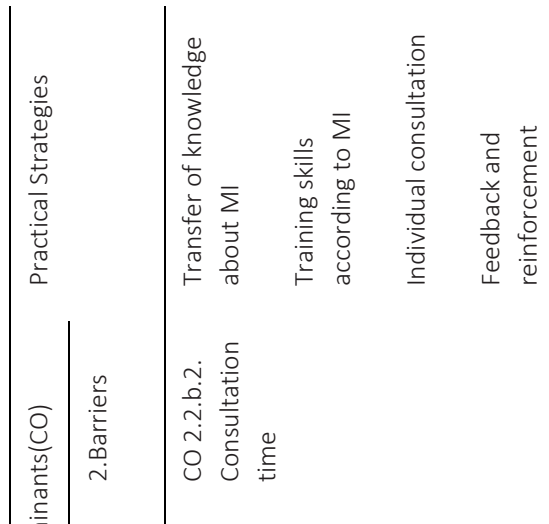

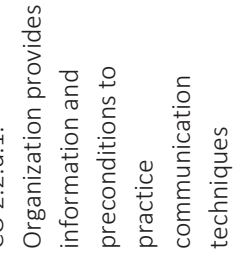

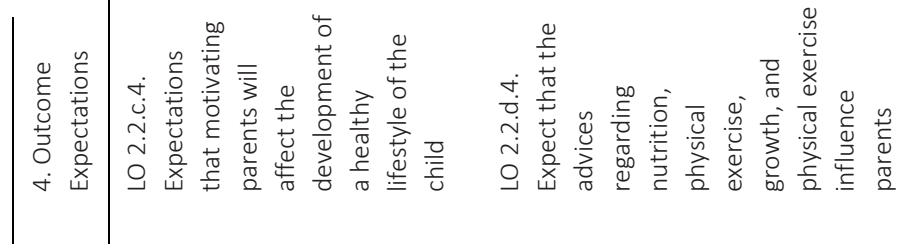

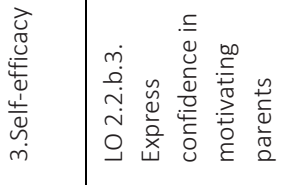

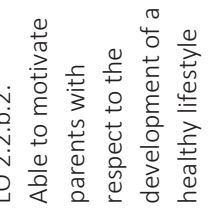

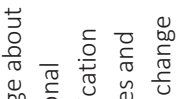

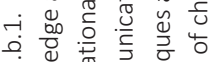

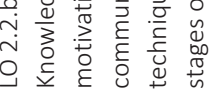

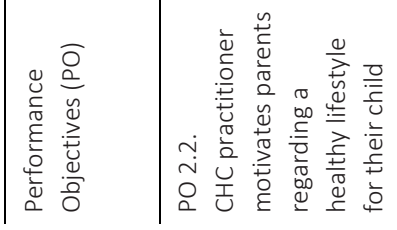




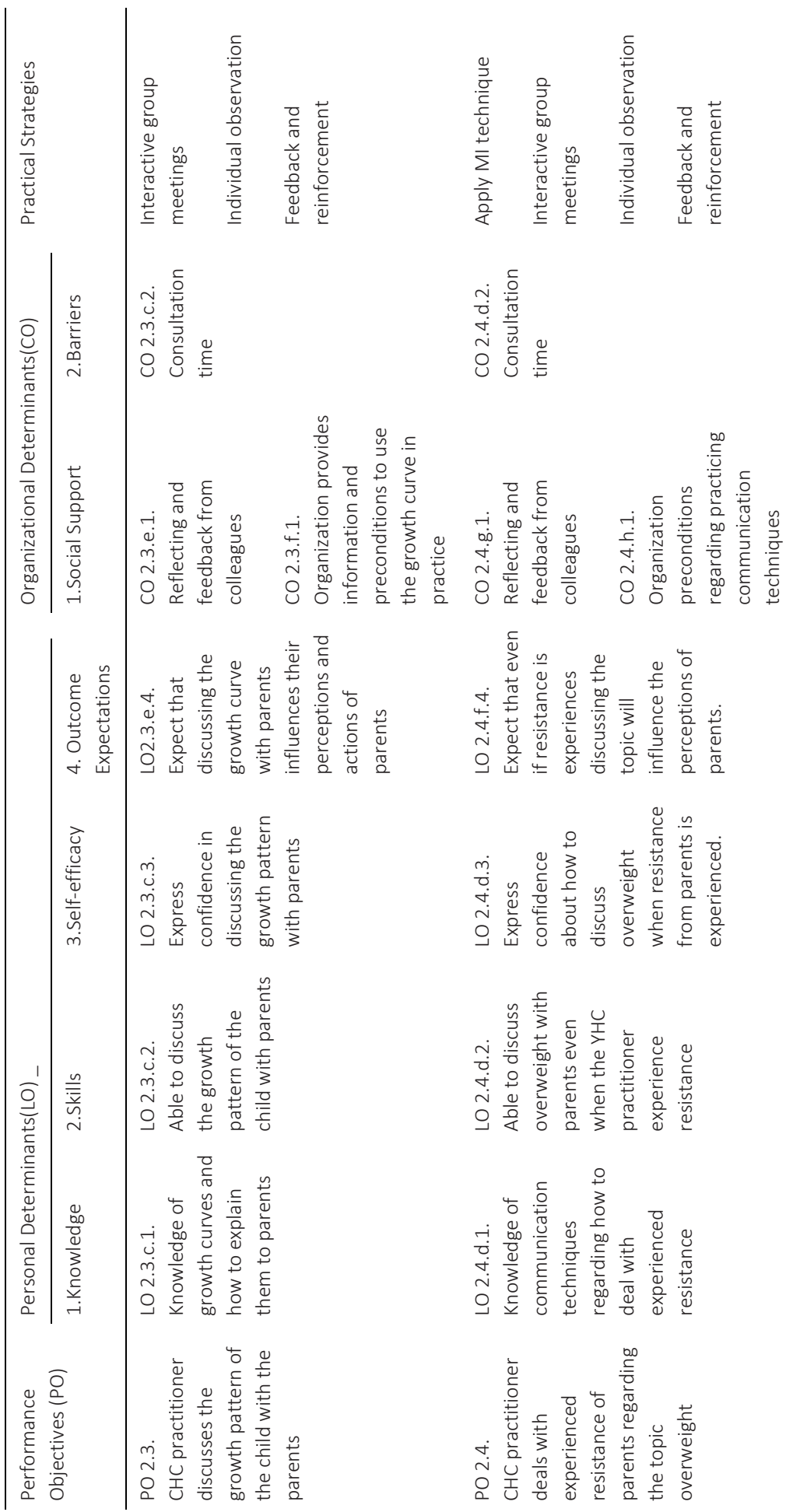




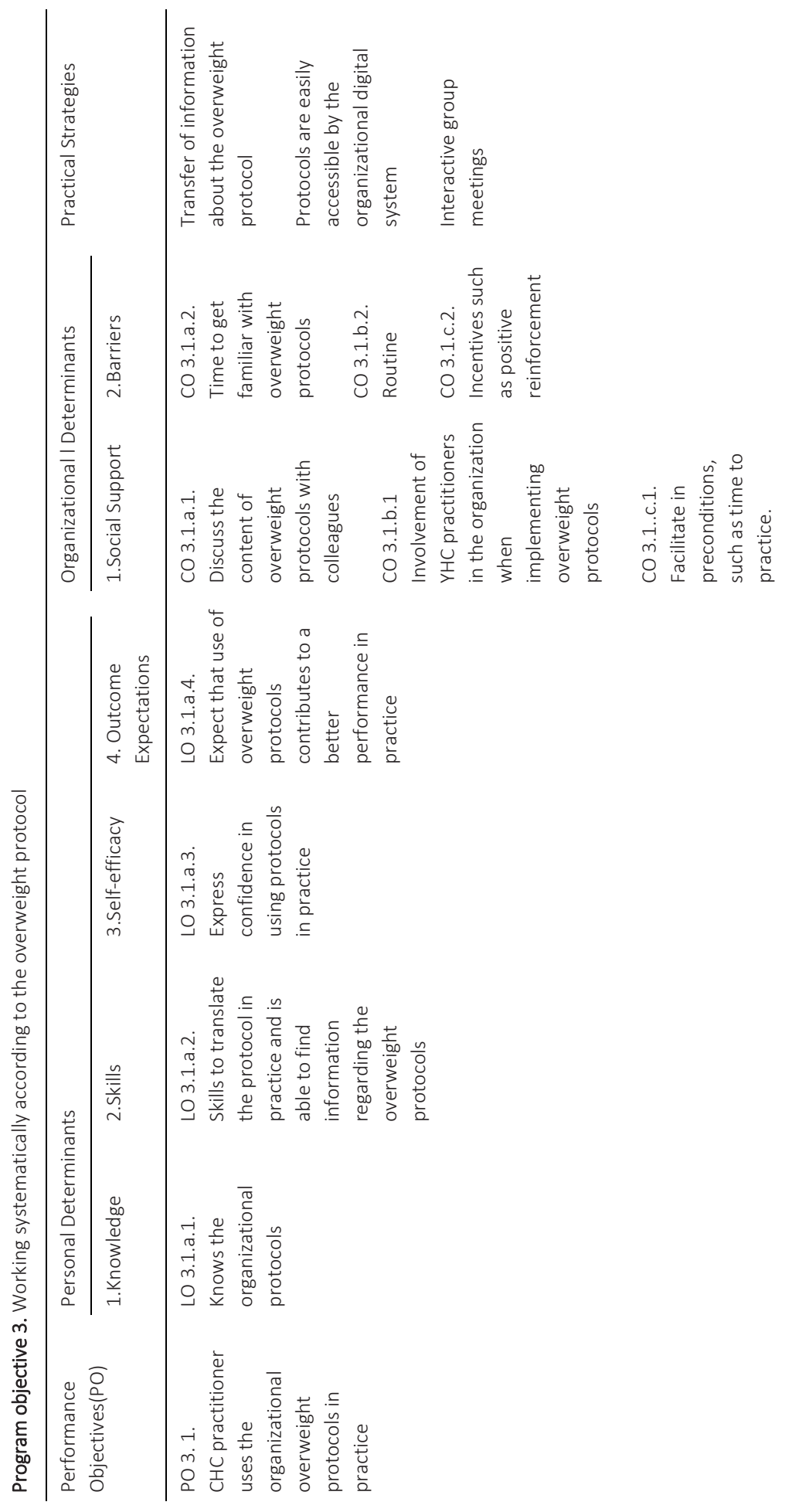




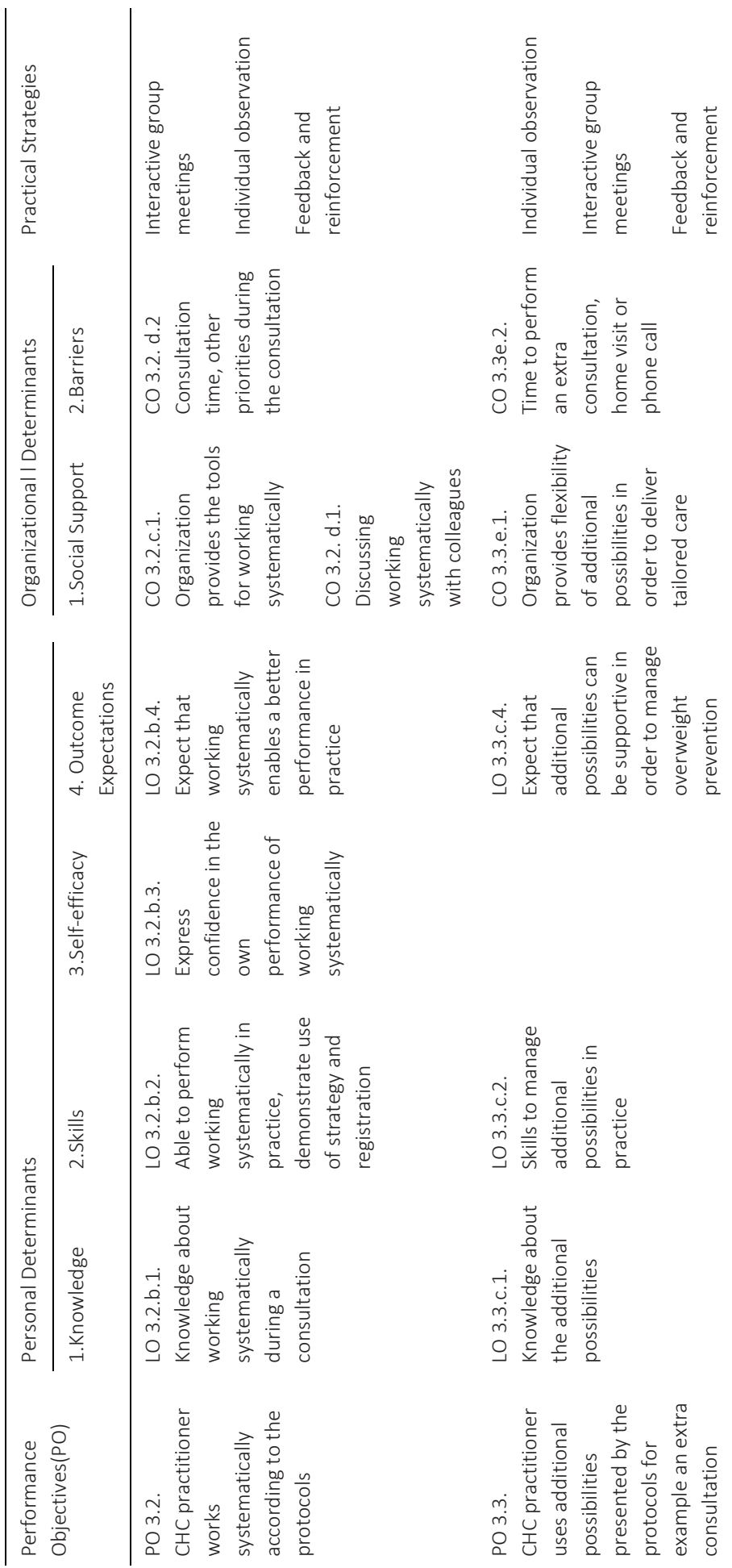




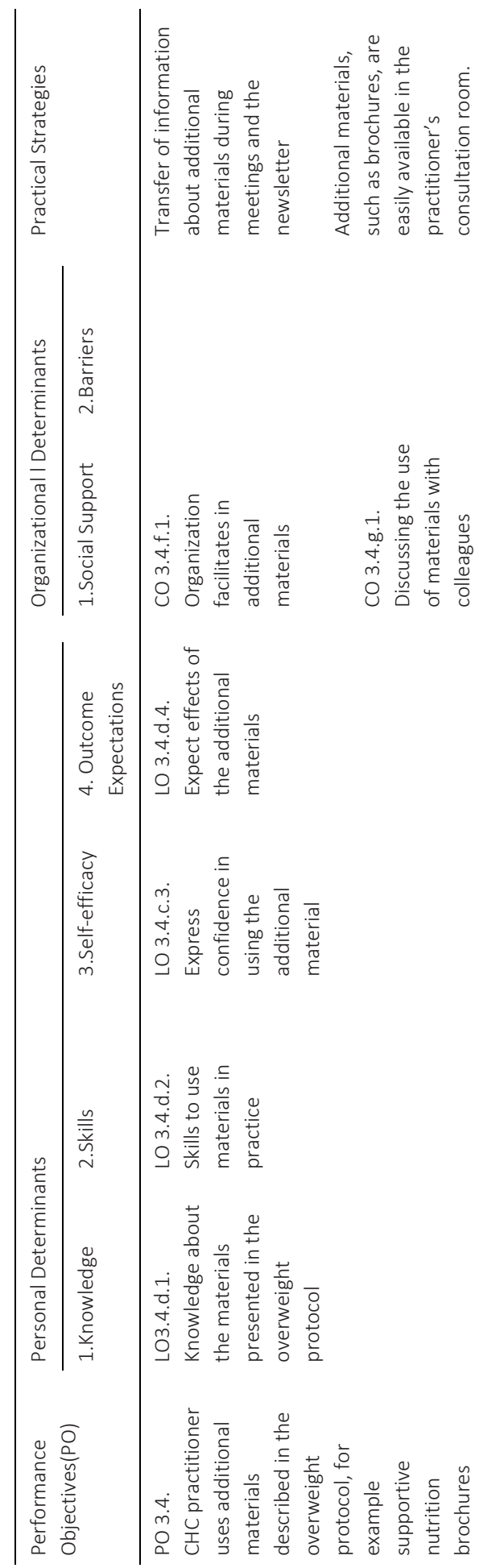




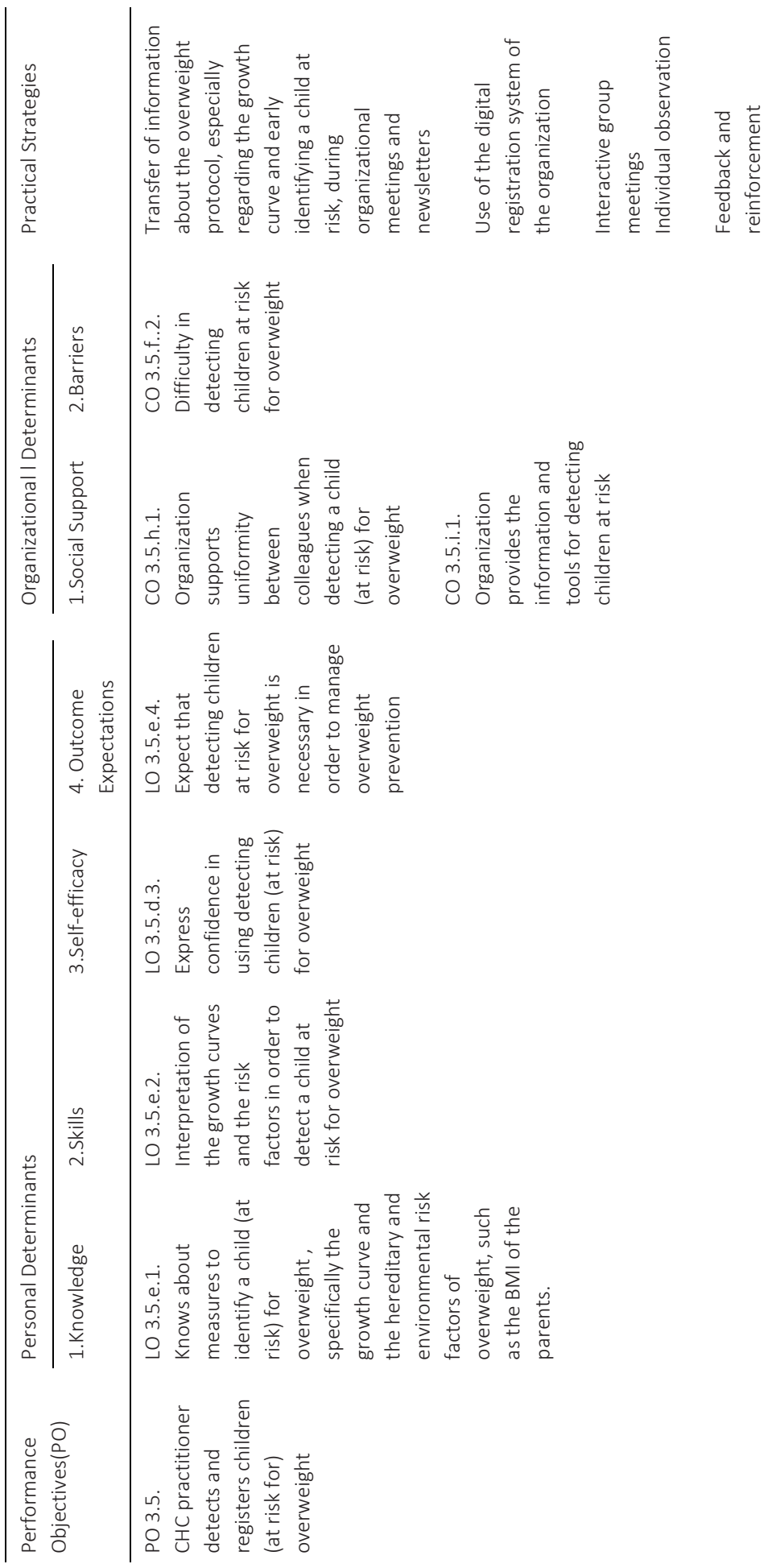


TRAINING PROGRAM

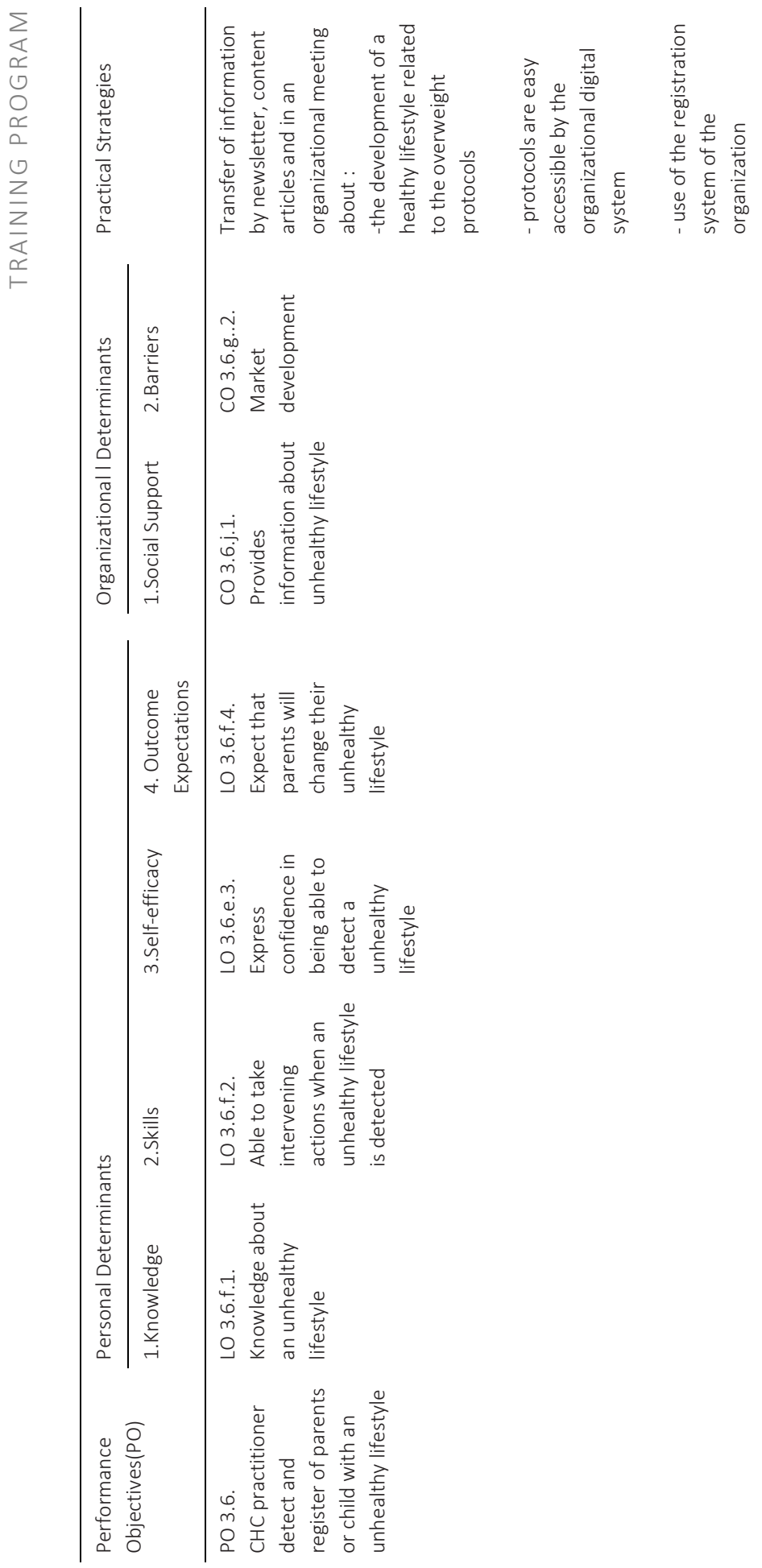




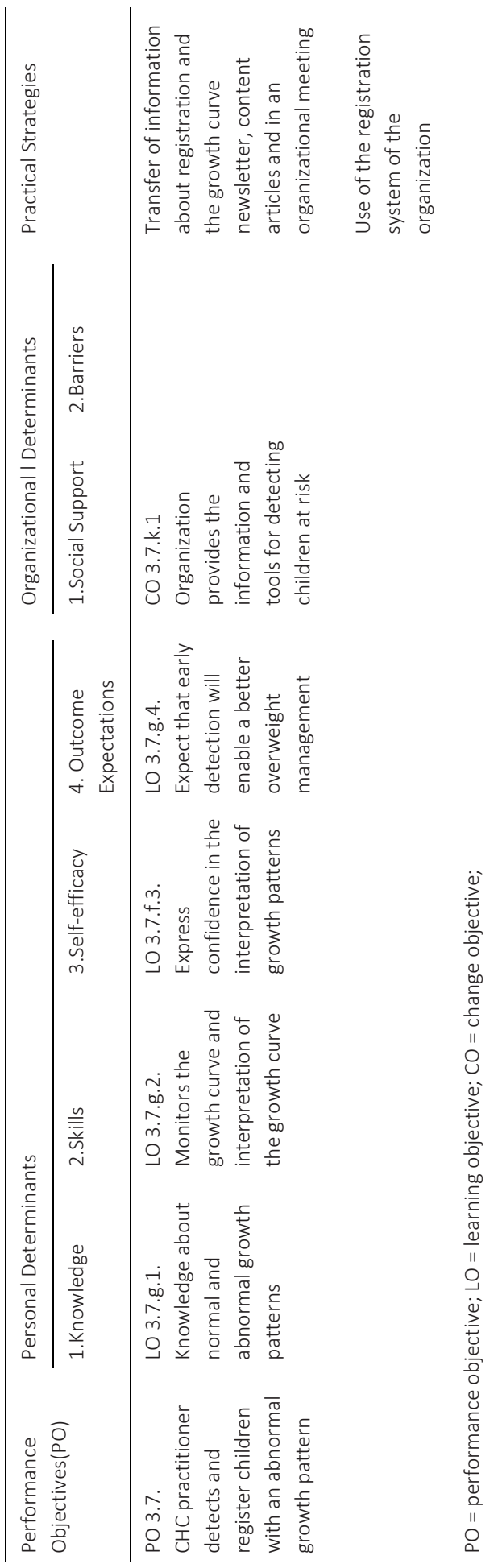




\section{CHAPTER 5}

Early prevention of overweight by child health care practitioners and the effect on the child's growth.

This chapter is submitted for publication by:

Dera-de Bie EGE, Jansen MWJ, Kuijk van SMJ, Zimmerman LJ, Gerver WJ 


\section{ABSTRACT}

Objective: To examine if a more active implementation of an overweight prevention protocol by a special developed training program for Dutch child health care practitioners influences the growth in the first two years of a child in a way that overweight is prevented.

Background: Overweight of children is a major social problem because of a lifelong risk for medical and psychosocial problems. Metabolic programming happens during the first months of life. Once a child is overweight it is difficult to achieve a healthy normal weight and therefore preventing children from becoming overweight is important. A basic task of Dutch child health care practitioners is early detection of children with abnormal growth and supporting parents with the development of a child's healthy growth and lifestyle. However, it is unclear whether this support actually affects the growth of a child.

Methods: Three growth cohorts of children born in a region in the south of Limburg, the Netherlands were compared. The participating children of one cohort got care of trained child health care practitioners and the participating children of the other two cohorts received care as usual. Weight and height from the participating children were collected at birth, at six months, one year and at two years during regular health visits. Differences between the three cohorts were tested with Anova and linear mixed models analysis.

Results: No difference were found between the three cohorts with regard to weight, length, weight SDS, height SDS, weight for height and BMI. There is no difference in growth of participating children between the trained group of child health care practitioners and the child health care practitioners that delivered care as usual.

Conclusion: A more active strategy to use the overweight protocol in practice by $\mathrm{CHC}$ practitioners has no effect on the growth of these children in a way that overweight is prevented. Although, health care practitioner's are vital in preventing and managing childhood overweight, a more collaborative and environmental strategy that tackles the obesegenic environment is also necessary. 


\section{INTRODUCTION}

Overweight has been recognized worldwide as a chronic disease because of the negative effects on health (WHO, 2000; WHO, 2015). Besides, it has social implications not only for the individual but also for the society as a whole. It is known that obesity is related to tremendous amounts of costs because in general these individuals participate less in society and are responsible for a large financial burden in health care (Branca, 2007). It is established that early childhood is a critical period for assessing the origins of overweight in adulthood. The velocity of the increase of weight at a young age predicts future weight in adulthood (Singh et al., 2008; Barker, 2007; Ong \& Loos, 2006). This statement is even true for the course of weight during infancy.

In the Netherlands, monitoring child growth and development is a routine part of child health care $(\mathrm{CHC})$ practitioners' duties. Of Dutch children, 90\%-95\% between 0 and 18 years of age participate in the CHC program (Wieringen \& Wieren, 2010). CHC practitioners main task is prevention, as they aim to detect abnormal growth and development as a possibility of underlying disease (Dunnink \& Lijs, 2008). For this reason, they are focused on overweight as a "disease". To support their preventive task, a training program has been developed as described in a former publication of Dera et al. (2013). This program focuses on a more active strategy with respect to the Dutch CHC overweight detection and prevention protocol (Veldhuis, 2009). The program intended a structural improvement of the knowledge of early detection of children who are at risk of overweight and the improvement of skills to discuss the problem of overweight with the parents. This training program was developed in accordance to the Intervention Mapping Framework, which is a systematic approach for program development (Bartholomew, 2006).

In this study the effect of the training program is primarily evaluated by investigating the course of weight during the first two years of life in three different cohorts. The CHC physicians and nurses of one cohort were trained as mentioned above, in the other two cohorts care was given as usual.

\section{METHODS}

Data were gathered from three different cohorts of children born between the 1st of August and the 31st of October 2009, in the region of southern Limburg, the Netherlands. Each region has its own $\mathrm{CHC}$ organization of which $\mathrm{CHC}$ practitioners work with children in the age category from birth until four years old.

For the study, children were followed from birth until the age of two years. Weight and height were recorded at birth, at six months, one year and two years. Trained practitioners carried out the measurements. All collected data were recorded as a part of the standard care and no extra data were collected for the benefit of this study. Not all 
children were measured at exactly the same age and for that reason the measured data were extrapolated to the nearest 'standard age' of measurement being birth, six months, one year months and two years. First descriptive statistics was performed and the results were expressed as mean and standard deviation scores of weight, height, weight SDS, height SDS, weight for height and BMI (weight in $\mathrm{kg}$ divided by square height in meters). As reference population the Dutch nationwide growth curves of 2010 were used (Schönbeck, 2010). For the SDS of weight for height the reference data of Paediatric Morphometric were taken (Gerver, 2001; Frederiks, 2005).

SPSS (statistical package for the social science (version 23.0) was used to analyse the data. Baseline characteristics of the children and practitioners were presented as mean and standard deviation, or as absolute number and percentage, where applicable. Differences at baseline were tested using analysis of variance (ANOVA) for continuous variables and Chi-square for categorical variables. For the longitudinal analyses of the differences between the three cohorts we used linear mixed models with random intercept, random slope, and with an unstructured variance-covariance matrix. All tests for differences between regions were corrected for baseline differences of that measure, gestational age at birth, and gender. A p-value $<0.05$ was regarded as statistically significant.

\section{RESULTS}

In table 1, baseline characteristics of the three different cohorts and the relevant characteristics of $\mathrm{CHC}$ practitioners are presented. The data of 1333 children were analysed; 376 children from organization A, 579 children from organization B and 378 children from organization C. Gender and pregnancy duration of premature vs term children were equally distributed. Also, relevant baseline characteristics of the three $\mathrm{CHC}$ organizations and their $\mathrm{CHC}$ practitioners are presented. There were no relevant differences between the three organizations. 
Table 1 Characteristics of the study population

\begin{tabular}{|c|c|c|c|c|}
\hline $\begin{array}{l}\text { Characteristics Cohorts and Organizations } \\
\text { Area }\end{array}$ & $\begin{array}{l}\text { A Maastricht } \\
\mathrm{N}=(\%)\end{array}$ & $\begin{array}{l}\text { B Heerlen } \\
\mathrm{N}=(\%)\end{array}$ & $\begin{array}{l}\text { C Sittard-Geleen } \\
\mathrm{N}=(\%)\end{array}$ & $\begin{array}{l}\text { P-value for } \\
\text { difference }\end{array}$ \\
\hline \multicolumn{5}{|l|}{ Characteristics of the cohorts } \\
\hline Children born in 2009 & 1519 & 1793 & 1243 & \\
\hline Participating children in cohort & $376(24.7)$ & $579(32.3)$ & $378(30.4)$ & \\
\hline Gender & & & & 0.896 \\
\hline Boys & 184 (48.9) & $292(51))$ & $193(51)$ & \\
\hline Girls & $192(51.1)$ & 287 (49) & $185(49)$ & \\
\hline Children born prematurly (<37weeks) & $33 \quad(8.8)$ & $45 \quad(7.7)$ & $51 \quad(13)$ & 0.008 \\
\hline \multicolumn{5}{|l|}{ Characteristics of $\mathrm{CHC}$ practitioners } \\
\hline Physicians & 9 & 16 & 9 & \\
\hline Nurses & 21 & 30 & 20 & \\
\hline Mean age of $\mathrm{CHC}$ practitioners (yrs) & 48 & 44 & 47 & \\
\hline Mean working years of $\mathrm{CHC}$ practitioners (yrs) & 13 & 13 & 15 & \\
\hline
\end{tabular}

In table 2 and figure 1 the outcomes of the anthropometric measures are presented. The results are specific for the group of children from birth to the age of two. The results of the linear mixed models show that no significant differences were found between the three cohorts at the measured ages, nor for mean weight, height, weight for height, or BMI. 
Table 2 Results in growth ( in mean and standard deviation) at birth and after 6 months, 1 and 2 years followup in control and intervention areas.

\begin{tabular}{|c|c|c|c|c|c|c|c|}
\hline \multirow[t]{2}{*}{$\begin{array}{l}\text { Measurements } \\
\text { and time }\end{array}$} & \multicolumn{2}{|l|}{$\begin{array}{l}\text { Cohort A } \\
\text { Maastricht }\end{array}$} & \multicolumn{2}{|l|}{$\begin{array}{l}\text { Cohort B } \\
\text { Heerlen }\end{array}$} & \multicolumn{2}{|c|}{$\begin{array}{l}\text { Cohort C } \\
\text { Sittard-Geleen }\end{array}$} & \multirow[t]{2}{*}{$\begin{array}{l}\text { P-value for } \\
\text { difference* } \\
*\end{array}$} \\
\hline & Mean & SD & Mean & SD & Mean & SD & \\
\hline Weight* & & & & & & & 0.345 \\
\hline At Birth & 3.4 & 0.52 & 3.37 & 0.57 & 3.33 & 0.61 & \\
\hline At six month & 7.77 & 0.78 & 7.57 & 0.78 & 7.66 & 0.23 & \\
\hline 1 year & 9.53 & 0.91 & 9.59 & 1.01 & 9.56 & 1.21 & \\
\hline 2 years & 12.76 & 1.38 & 12.77 & 1.41 & 12.89 & 1.57 & \\
\hline Weight SDS & & & & & & & 0.455 \\
\hline At Birth & 1.07 & 1.44 & 0.96 & 1.65 & 0.84 & 1.74 & \\
\hline At six month & 0.22 & 1.17 & 0.25 & 1.17 & 0.41 & 1.41 & \\
\hline 1 year & -0.62 & 1.01 & -30 & 1.08 & -0.24 & 1.29 & \\
\hline 2 years & 0.16 & 1.02 & 0.14 & 0.14 & 0.2 & 1.11 & \\
\hline Height * & & & & & & & 0.117 \\
\hline At Birth & 50.25 & 2.58 & 50.06 & 2.64 & 49.99 & 2.81 & \\
\hline At six month & 67.06 & 2.3 & 67.05 & 2.38 & 67.1 & 2.57 & \\
\hline 1 year & 74.88 & 2.47 & 74.79 & 4.15 & 74.96 & 2.73 & \\
\hline 2 years & 88.41 & 3.2 & 88.69 & 3.47 & 89.01 & 3.47 & \\
\hline Height SDS & & & & & & & 0.071 \\
\hline At Birth & 0.16 & 1.12 & 0.01 & 1.31 & -0.03 & 1.4 & \\
\hline At six month & 0.11 & 1.48 & 0.11 & 1.44 & 0.19 & 1.84 & \\
\hline 1 year & -0.26 & 1.04 & -0.25 & 1.12 & -0.26 & 1 & \\
\hline 2 years & -0.13 & 0.92 & -0.07 & 0.99 & 3.33 & 0.61 & \\
\hline WfH SDS & & & & & & & 0.681 \\
\hline At Birth & 0.56 & 0.97 & 0.59 & 1.05 & 0.56 & 0.97 & \\
\hline At six month & 0.16 & 0.86 & 0.2 & 0.84 & 0.15 & 0.86 & \\
\hline 1 year & 0.24 & 0.77 & 0.3 & 0.85 & 0.24 & 0.77 & \\
\hline 2 years & 0.48 & 0.84 & 0.42 & 0.82 & 0.49 & 0.84 & \\
\hline \multicolumn{8}{|l|}{ BMI 2 years } \\
\hline & 17.40 & 1.62 & 17.39 & 1.63 & 17.50 & 1.79 & 0.61 \\
\hline
\end{tabular}

*Weight is in kilo, height is in meters

** Adjusted for baseline differences in gender and gestational age at birth using linear mixed models 

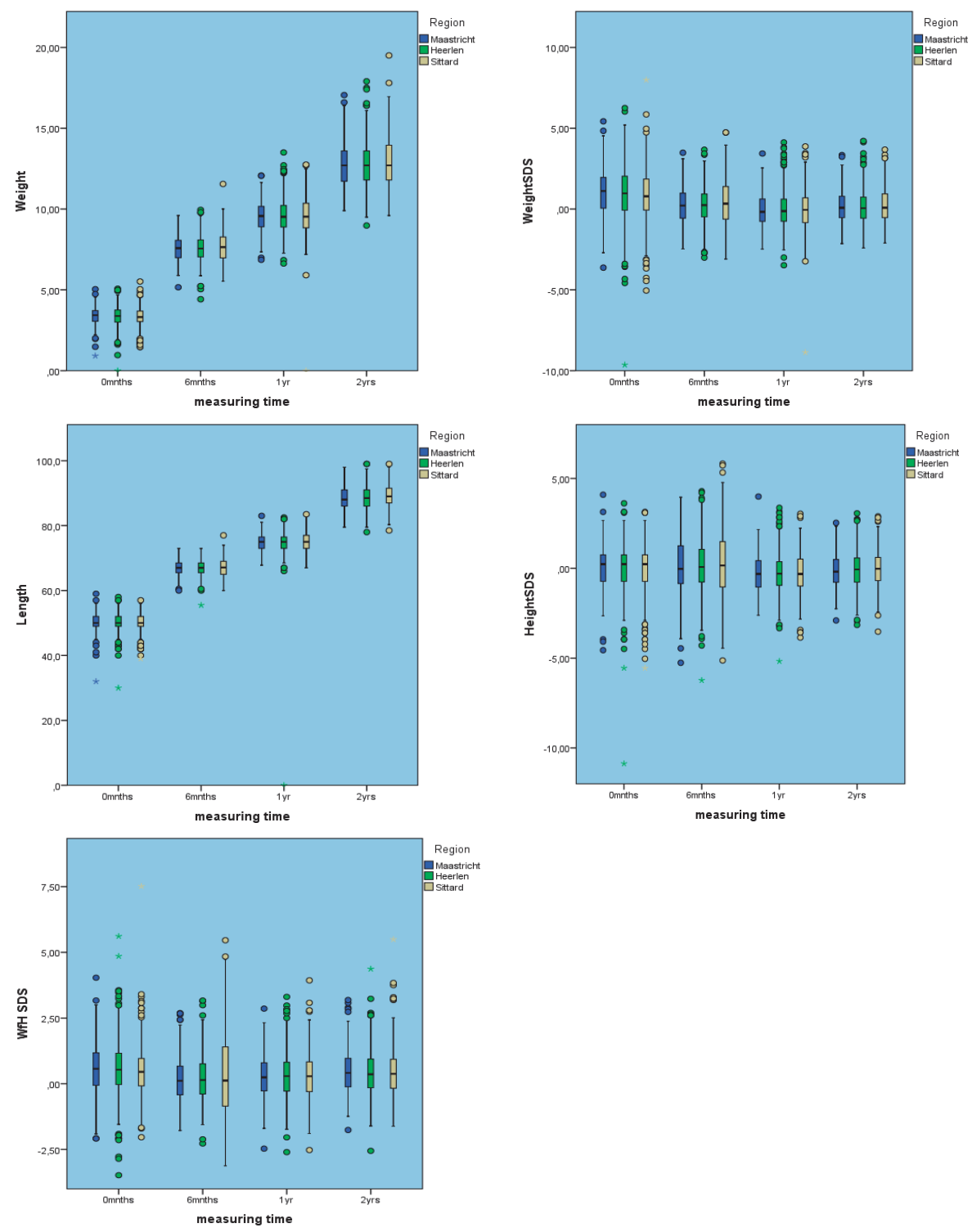

Figure 1 Results in growth ( in mean and standard deviation) at birth and after 6 months, 1 and 2 years followup in control and intervention areas. 


\section{DISCUSSION}

Because it is clear from a number of studies that the problem of overweight starts already in the first year of life, a training program was developed to increase the attitude of $\mathrm{CHC}$ practitioners on early detection and intervention from birth on. This training program was part of an intervention study and resulted in a clear difference on the variables of attitude and awareness between three groups of $\mathrm{CHC}$ practitioners, one with trained and two with untrained participants (Dera, et al, 2013). While at baseline, before training, there was no difference between the groups of $\mathrm{CHC}$ practitioners, after training the group who followed the training program showed a better result on these variables attitude and awareness (Arentsen et al, 2009; Dera, 2013). Therefore we anticipated that the training would result in measurable effects on weight, length, weight SDS, height SDS, weight for length and BMI. However, there were no differences between the outcomes of their anthropometric measures.

From earlier research (Dera, 2013) it was known that a more active implementation strategy, especially aimed at upgrading knowledge and skills of $\mathrm{CHC}$ physicians and nurses improves the detection of children at risk for overweight. However, the result of the counseling and mediating activities of the $\mathrm{CHC}$ practitioners seems to depend especially on the motivation of the parents to change their lifestyle behavior (Mikhailovich, 2007). CHC practitioners experience the motivation of parents as the largest barrier.

Not following the advice from health care practitioners, that is non-compliance, is a well-known phenomenon in health care. Most counseling performances are aimed at increasing knowledge of a healthy lifestyle and how to translate this knowledge into every day use. At the same time, it is known that the prevalence of overweight is higher by low social economic status (SES) and it seems from practice that parents from low SES learn better from practical teaching instead of increasing knowledge through verbal methods. The relationship between SES and unhealthy behaviors has been well demonstrated (Wang \& Beydoun, 2007). Many people use the argument of finance as a reason for less exercise (e.g. joining gym club) and a less healthy diet. Especially in the low SES group a positive practitioner-patient relationship is the most important factor in improving compliance. Making decisions together about the self care of a healthy lifestyle could improve the lack of patient motivation in treatment.

This motivation is especially difficult to reach in the environment of western society, which is built up by a food industry with a marketing strategy focused on unhealthy food products. Although the industry is obliged to put a label on food products with information about the composition of the product, it seems to have less effect especialIy on the low SES group (Grunert et al., 2010). Besides, in the last decades western society changed also into an obesogenic environment by a more sedentary lifestyle and 
again it seems that the lower social groups are more vulnerable for this new circumstance (WHO, 2015).

In addition, from previous research CHC practitioners working in a low-SES area experienced less effect on their recommendations regarding physical activity and the overweight prevention protocol (Dera, 2015). More insight into the influence of SES and the related health behaviors by parents and their young child is necessary in order to develop effective overweight prevention activities.

As stated before, we tried to get better insight into the child's early weight development. Weight for height is used in this study, because only weight as an absolute value has no meaning until it is expressed as part of height in the sense of weight for height or as BMI defined as weight $(\mathrm{kg})$ divided by height $\left(\right.$ meters $^{2}$ ). The BMI gives information about weight for height as an expression related to age while weight for height as two dependent variables tells us about the value of a certain weight for a certain height independent of age. In CHC practice, the BMI is used for children over the age of two as a measurement to detect overweight (Cole, 2000).

Further, the velocity of weight in the child's first year can be a predictor of overweight in childhood and early detection is essential in the prevention of it (Dennisen, 2006). It needs the recognition of any growth deviation from normal, which is especially difficult when a child starts deviating from its normal growth pattern although the actual weight and height are still within in the range of normality. For that reason a implementation tool of the measurements of height, weight and the related outcomes was developed by Ernst et al (2014) to detect a child at risk for overweight already at an early age.

This tool can be helpful for the practitioner in the task of early detection but also in the communication between CHC practitioner and parents (Ernst, 2014).

Only a few studies focused on preventing children from becoming overweight between birth and the age of two years. Our study was performed in daily practice and not set up as a randomized clinical trial. A randomized trial can make the study more robust. But the results may be less applicable in daily $\mathrm{CHC}$ practice where uncontrolled external environmental factors can influence the effect of the outcome of the anthropometric measures. Such environmental influence is for example the appointment of a lactation expert to supports mothers in their breastfeeding practices, which is also compensated by the medical insurance of the child.

A limitation of this study is that no information is available on, for example, the SES of the parents, parental BMI, maternal smoking, receiving breastfeeding or ethnic background. Another limitation is the duration of our study. We were able to realize a follow-up of two years which might be too short to result in adequate competences of $\mathrm{CHC}$ practitioners to effectively discuss parental barriers. 
A strength of the study is that more than $95 \%$ of the children born between the 1st of August and the 31st of October 2009 are included in this study. Because of the high percentage of included participating children, they are a plausible representative group for the children in the age category from birth to 2 years born in the region in question.

Another strength is that the data were collected prospectively from birth onwards and it was embedded in the routine $\mathrm{CHC}$ practice, which excludes the possibility of response bias. Also, height and weight of the children were measured by trained practitioners.

In summary, overweight is as well an individual as a collective health and social problem. A lot off interventions programs are developed and performed, also for children. Most overweight studies are focused on already overweighed children and not on preventing a child to become overweight (De Kroon et al, 2011). Besides, treatment of childhood obesity remains largely ineffective (Ebbeling, 2002). For that reason, early detection and prevention is a main tool of the $\mathrm{CHC}$ practitioner, which starts already in the first year of a child's life. Although the CHC practitioner has an important role in the prevention of overweight, the parents are the most important persons since they lay the foundations for their child's healthy lifestyle (Kelder et all, 1994). Yet, parents are most influenced by their own social environment and the increase of overweight can often be ascribed to their social habitat. People adapt to the environment and are not purely genetic creatures as known from studies of Barker (2007) and Doak (2006). In this study it is shown that the role of the $\mathrm{CHC}$ practitioner is primary detection of abnormal growth and in addition to communicate and motivate the parents to prevent further deviation. The individual counseling of $\mathrm{CHC}$ practitioners may contribute to increase the awareness about the importance of a healthy weight starting from birth on and it may avoid more overweight by children. At last, to tackle the overweight as an epidemic, it seems that a more collective environmental approach is necessary. 
CHAPTER 6

General discussion 



\section{INTRODUCTION}

Looking at todays' children, it is remarkable how many appear to be overweight. As a professional child health care $(\mathrm{CHC})$ physician or nurse you wonder how it is possible that this remains the case despite the large number of prevention programs (Doak, 2006). This provided the stimulus for starting the present research project, to investigate if a more active implementation of the overweight prevention protocols would have a positive effect on the early detection and counseling of children at risk for overweight. The project involved the development of a specially tailored training program for $\mathrm{CHC}$ physicians and nurses. Since it is known that the development of overweight during childhood results in a risk of cardiometabolic diseases in adulthood, this prevention program focused on children in the period from birth until the age of two (Ong \&Loos, 2006; L'Allemand-Jander, 2010).

Overweight is a worldwide problem, which is associated not only with many personal health problems but also with effects on society as a whole (WHO, 2015). The personal health problem is the development of the metabolic syndrome, a cluster of disorders involving dyslipidaemia, atherosclerosis and hypertension, all probably based on insulin resistance (Alberti et al., 2005, 2009). The syndrome adds up to a shortening of life. The costs to society include not only those of individual health care, but also the negative effects on the quality of life, causing a lifelong economic burden (Branca, 2007). Central to the prevention of overweight development is communication with the parents, with health care practitioners as important mediators (Mikhailovich, 2007). They are in a position to inform parents about the generally incorrect and outdated idea that in the case of infants, being "fat" is being "healthy". The Dutch CHC organization acknowledges that they have a task and has therefore developed an overweight prevention protocol (Dunnink \& Lijs, 2008). Yet information from practitioners and the literature suggests that this protocol is not being used by the $\mathrm{CHC}$ physicians and nurses as intended. The studies reported on in this thesis investigated "what" can be improved and "how" it can be improved, and "what" are the effects of the improvement.

\section{AIM OF THE RESEARCH PROJECT}

This research project had two main objectives:

1. to develop a training program for $\mathrm{CHC}$ practitioners based on an assessment of their needs, and

2. to test the effect of the training program in terms of characteristics of $\mathrm{CHC}$ practitioners and on the course of the growth of children from birth until the age of two years. 
First we tried to identify the most relevant and modifiable factors with respect to the implementation of the overweight prevention protocol, in a so-called needs assessment. $\mathrm{CHC}$ practitioners were interviewed and a quantitative study was done using a self-report questionnaire. Second, based on the most important inhibiting factors reported by the practitioners, a training program was developed using the interventionmapping (IM) framework, with the aim of improving overweight prevention from a child's birth onward (Bartholomew, 2006). A group of $\mathrm{CHC}$ physicians and nurses of one organization, the so-called intervention group, were trained. The results of this training were evaluated by means of a logbook and by comparing the intervention group with two control groups, again using the self-report questionnaire. Finally, the effect of the training program was evaluated by investigating the course of children's weight from birth to the age of two years in the three cohorts of children counseled by the intervention group and the two control groups. This chapter summarizes the main findings of this study and describes implications for practice and future research.

\section{MAIN FINDINGS}

\section{Needs assessment}

The needs assessment identified three major inhibiting factors. First, it became clear that there is a lack of awareness that a child's first year is an essential period for the prevention of overweight. Besides it was not clear to the respondents when a certain progress in weight implies a risk for the development of overweight even though the observed weight is still within the limits of normality. Second, communicating with parents about the risk of overweight was experienced as very difficult. Finally, there was a lack of systematic working methods, resulting in inadequate implementation of the overweight prevention protocol. However, it is essential to examine not only the inhibiting factors experienced by the $\mathrm{CHC}$ practitioners, but also organizational factors and support, which are crucial regardless of whether a protocol is correctly implemented or not. From this study it became clear that there is especially insufficient attention for the maintenance of the protocol implementation.

\section{Training content and implementation}

Based on the results of the needs assessment, objectives were defined for the training program. The main program objectives were to ensure that:

(1) CHC practitioners are aware that prevention of overweight starting from birth is important; (2) CHC practitioners are competent to discuss the risk of overweight with parents; and (3) CHC practitioners work systematically according to the overweight prevention protocol. Using the intervention mapping framework, a matrix was then 
constructed specifying appropriate theories and practical strategies, in order to define what $\mathrm{CHC}$ practitioners have to learn and what has to be changed in their working environment. The content of the training program consisted of 8 components:

1. a kick-off meeting with information about the project;

2. an expert meeting to increase knowledge about the topic and to discuss the content of the project;

3. a skills training course for using the Motivational Interviewing technique;

4. interactive group meetings to encourage the exchange of knowledge between colleagues;

5. observations of the performance of individual practitioners by a trainer;

6. discussing newsletters as a tool for information transfer;

7. discussing related published articles;

8. interactive discussion of questions by mail or telephone;

The training program was embedded in the $\mathrm{CHC}$ organization in order to promote the adoption of the new working method. The main strategy of the training program was that of repetition of information and practicing risk communicating skills.

To evaluate the training program, a self-report questionnaire about competence and organizational support was used at baseline and at 1-year follow-up. This was completed by 61 of the total number of $105 \mathrm{CHC}$ practitioners working in the Southern Limburg region.

\section{Results}

The results of the training program show increased awareness among $\mathrm{CHC}$ practitioners of the risk factors in a child's first year and the development of overweight into adulthood, more familiarity with the overweight protocol and more focus on the maintenance of the overweight prevention protocol by the organization.

However, no difference was found between the three cohorts of children as regards the course of their weight

\section{CONSIDERATIONS}

\section{The needs assessment and the training program}

Data triangulation was used for the needs assessment, and the combination of qualitative interviews and a quantitative study using a self-report questionnaire strengthens the identification of the major barriers in this study. The use of the IM framework, which is also based on data triangulation and uses an iterative approach instead of a linear one, provided the opportunity to further tailor the training program to everyday 
$\mathrm{CHC}$ practice. The advantage of using the IM framework is that it is systematic, evidence-based and theory-driven, which also includes the translation of knowledge and skills into everyday practice. However, IM is often a time-consuming process, so its complexity was reduced for the purpose of our study. In general, when it comes to saving time and money and avoiding the wheel being reinvented, it is useful to investigate what has already been developed. Often there is no lack of protocols or materials. Enhanced knowledge and skills among $\mathrm{CHC}$ practitioners can help to overcome barriers and ensure better adherence to a protocol in practice. Our study evaluated the effect of a new working method, and we intended to contribute to a more evidence-based use of overweight prevention care in daily practice, starting from birth. Fleuren et al. (2014) developed a measurement instrument for determinants of innovations, called MIDI, which we used to investigate protocol adherence.

Although the training program spent much time discussing the risk of overweight with parents, this still seems to be one of the main barriers experienced by $\mathrm{CHC}$ practitioners. The practitioners recorded the weight and height of the parents during their first $\mathrm{CHC}$ visits, because parental overweight is one of the major risk factors for a child becoming overweight. In case of abnormal findings, the $\mathrm{CHC}$ practitioners found it even more difficult to discuss this with the parents, because of the expected emotional responses or concerns about stigmatization. Communicating both the child's weight and that of the parents is the first step to effective weight management, and improving this communication and teaching practitioners how to deal with the parents' emotional responses can improve the quality of early overweight prevention. When discussing the risk of overweight with parents, research suggests that the focus should be more on the child's health instead of only on its weight (Mikhailovich, 2007). Also, a more helpful and less blame-oriented approach should result in better communication between parents and practitioners. More support for $\mathrm{CHC}$ practitioners is desirable with respect to communicating with parents about the risk of a child's overweight. In addition to the fact that practitioners experience risk communication as difficult, it also seems that there is a gap between the recommendations made by the $\mathrm{CHC}$ practitioners and the actual changes by parents to make healthier choices for their child. If a child is detected to be at risk for becoming overweight, the intervention is mostly only focused on a healthy nutrition and physical activity of the child instead of also supporting parents in achieving a healthier lifestyle themselves (Hesketh \& Campbell, 2010). Furthermore, organizations often take too little interest in the maintenance and evaluation of a new working method, which makes it more difficult to know the real effect over time of better protocol adherence by $\mathrm{CHC}$ practitioners and the effect of this improvement on the course of a child's growth.

Our study showed that a more active and structured approach benefits adherence to overweight protocols in daily practice. When practitioners have the expertise to prevent overweight, have a positive attitude towards prevention among young children and feel confident about discussing the problem, this is associated with better protocol 
adherence. Our study found, for example, that $\mathrm{CHC}$ practitioners who had more knowledge also made better use of the relevant materials in practice.

\section{The methodological considerations}

When it comes to performing a study in daily health care practice instead of under controlled conditions, it is obvious that several environmental factors can have an influence. For example, during this study the $\mathrm{CHC}$ organizations changed from a paper-based child data registration system to a digital system. In addition, there were funding cuts in health care. Research in the real world reflects the huge variety of the natural environment and the extent to which these environmental factors affect the outcome variables in studies. Research in the real world thus complements controlled studies (Green, 2008).

One strength of the studies presented in this thesis is that a logbook was used to monitor the process of implementing the training program, and this is evaluated at different levels (practitioner, organization and child). Another strength was that the development and implementation of the training program were coordinated and supported by one of the program developers, who also worked in $\mathrm{CHC}$ practice. This has the advantage of providing a better alignment with the internal processes of an organization, resulting for example in a high response rate for the self-reported questionnaires (93\%). A limitation of this approach can be that $\mathrm{CHC}$ practitioners provided more socially desirable answers to in the self-reported questionnaire. Another limitation was that our study focused on the CHC practitioners. However, it is not only the CHC practitioners who have to change their behavior by applying a new working method; parents also have to be motivated to change their lifestyle choices to improve the health of their child. It is known that changing behavior takes a long time and the study period may have been too short. It is also not clear from our findings if parents actually followed the advice given by the CHC practitioners. In addition, there was no logbook evaluation of the control groups. Perhaps if public health organizations and $\mathrm{CHC}$ organizations start to spend more time and effort on evaluating efficacious preventive overweight interventions this could improve the support given to parents by the $\mathrm{CHC}$ practitioners. In general, our findings about the main barriers can be generalized to the Dutch $\mathrm{CHC}$ system, as the overweight protocol is used by all $\mathrm{CHC}$ organizations in the Netherlands.

Whereas in many studies the recruitment of participants is often disappointing, this was not the case in ours. Almost all children born between 1 August and 31 October 2009 in the Southern Limburg region were included. This high participation rate of children in this study was achieved because the attendance rate to the $\mathrm{CHC}$ visits by parents and their children was 95\% or more (Wieringen \& Wieren, 2010). Another strength of our study is that we collected data on the weight and height of the children, as this data was systematically collected and its collection was part of the work routine of the 
$\mathrm{CHC}$ practitioners. The Dutch $\mathrm{CHC}$ organizations systematically monitor the weight and height of children from birth onward, in a uniform way, and this can set an example for $\mathrm{CHC}$ organizations in other countries. Monitoring this data enables early detection of abnormal growth and thereby possibly the identification of underlying diseases. In our study the data of the growth cohort was collected over a two-year period, which made it possible for us to longitudinally evaluate the outcome of the training course in terms of children's weight development (growth).

\section{Implications for practice}

This study has several implications for $\mathrm{CHC}$ practice. In current practice, while it is clear when a child is overweight, there is no good measurement instrument to show when a child is at risk for overweight when its actual weight is still within the limits of normality. It is especially in the case of children aged between zero and two years that it is difficult for $\mathrm{CHC}$ practitioners to detect aberrant weight increase patterns. Clinical view and professional expertise are currently the indicators commonly used for early detection. A study by Ernst investigated a new method based on the change of weight, height and weight-for-height, which is very useful in the daily practice of $\mathrm{CHC}$ practitioners or other health care professionals working with children (Ernst, 2014). This new method is a prediction model which makes it possible to estimate a child's growth pattern. The model enables the detection of children who do not fit the predicted growth pattern, so early interventions can be deployed.

It could also be helpful for all CHC practitioners if not only height but also weight of the parents was routinely included as a measurements to detect a child at risk for overweight. If this becomes a standard measurement, it would makes it easier to discuss abnormal findings in terms of parental weight and the correlated risk of overweight in the child.

\section{Implications for future research}

The results from this study suggest that there is a lack of awareness among $\mathrm{CHC}$ practitioners that a child's first year is an important period in the prevention of overweight. In general, there should be more focus on a population-based approach to increase the awareness among parents as well as health care practitioners about the fact that a "fat baby" often results in a "fat adult", which is a result of lifestyle choices such as what and how much they eat and how physically active they are.

Only a few studies have directly discussed the difficulty of communication on these issues between practitioners and parents. Health care practitioners often use terms such as overweight, obesity, too fat, or chubby, to describe a child's excess weight, but these words are often considered stigmatizing by parents. The context in which the words are used is very important, and a more supportive relationship between health 
practitioner and parents is therefore essential. The terms should not be avoided, but more important is to understand what the child's weight means to the parents. The focus should be more on weight in relation the child's health, instead of blaming the victim. Discussing the topic can help to reveal the barriers experienced by parents and help to motivate and support parents with regard to healthier choices for their child.

Earlier research has found that there is a difference between physicians and nurses with respect to knowledge and skills regarding overweight prevention care. Nurses have a more central supportive role than physicians when it comes to lifestyle support for parents and their children, while physicians generally have more knowledge of medical overweight problems. Physicians could support nurses with respect to increasing their knowledge about the growth of a child and related diseases.

More insight into the different tasks of health care practitioners involved in overweight prevention and more emphasis on their needs could help to improve the coordination between these practitioners in carrying out their task of reducing overweight.

Social media are offering new ways of communicating, with low accessibility threshold. They can also provide parents with a better understanding of their child's growth chart and provide new opportunities to reach a wider range of people, disseminating information and increasing knowledge in order to tackle the overweight epidemic. In addition, social media can support parents by providing information about a child's normal growth rate patterns by means of mobile phone applications (apps) (Dommelen, 2015). If a parent using such an app is concerned about the growth of their child, they should be able to discuss this with a health professional. Future research could investigate the interaction is between using an app, consulting $\mathrm{CHC}$ practitioners and parental behavior.

The so-called MIDI instrument developed by Fleuren et al. (2014), which assesses determinants of innovations, can contribute to better effect measurements of protocol adherence. It would be interesting to further research the implementation of this model in $\mathrm{CHC}$ organizations and to examine if this model could also contribute to a better outcome in terms of the protocol targets.

\section{GENERAL CONCLUSION}

It appears from the literature that overweight will remain a problem over the coming decades. One of the reasons is the expected development of still more technology associated with a more sedentary lifestyle. Also, the increased marketing and promotion of unhealthy food products has a negative influence on overweight rates among the young. The food industry is promoting more artificial (special) baby milk, which contributes to a decline in breastfeeding rates (Smith, 2007). It has also been known for several years that the intake of fruit and vegetables among the entire Dutch population is low (RIVM, 2015). At the same time, the food industry is promoting a lot of different nutri- 
tional supplements, such as fruit drinks for babies, and the food industry is even considering producing artificial milk with the taste of vegetables or fruit. For health care practitioners, it is difficult to promote healthy nutrition and to get people to follow their recommendations against the influence of the powerful food industry, which promotes "unhealthy" food. This "unhealthy" food industry can harm the health of infants and young children, as children are one of the groups that are most vulnerable to the tactics of this food industry. Fortunately, a study by the Dutch Heart Foundation (2015) found that parents recognized the negative effect of marketing on their children, and most parents said that stricter rules are necessary for marketing targeting children.

Child health care organizations see almost all children from birth onward, and they see not only overweight children, giving them opportunities to provide health promotion and healthy lifestyle education for all children, to keep them all healthy. In addition, $\mathrm{CHC}$ organizations have the opportunity of detecting children at risk for overweight at an early stage, and supporting these children through individual counseling of the parents. $\mathrm{CHC}$ can therefore contribute to a more collective preventive approach to tackle the problem of the development of overweight among children. 
CHAPTER 7

References 

1. Agras WS, Hammer LD, McNicholas F, Kraemer HC. Risk factors for childhood overweight: a prospective study from birth to 9.5 years. J Pediatr2004 Jul;145(1):20-5.

2. Aguilar M, Bhuket T, Torres S, Liu B, Wong RJ. Prevalence of the metabolic syndrome in the United States, 2003-2012. JAMA2015 May 19;313(19):1973-4.

3. Alberti KG, Eckel RH, Grundy SM, Zimmet PZ, Cleeman JI, Donato KA, et al. Harmonizing the metabolic syndrome: a joint interim statement of the International Diabetes Federation Task Force on Epidemiology and Prevention; National Heart, Lung, and Blood Institute; American Heart Association; World Heart Federation; International Atherosclerosis Society; and International Association for the Study of Obesity. Circulation2009 Oct 20;120(16):1640-5.

4. Alberti KG, Zimmet P, Shaw J. The metabolic syndrome--a new worldwide definition. Lancet2005 Sep $24-$ 30;366(9491):1059-62.

5. Alemi F, Neuhauser D, Ardito S, Headrick L, Moore S, Hekelman F, et al. Continuous self-improvement: systems thinking in a personal context. Jt Comm J Qual Improv2000 Feb;26(2):74-86.

6. Anzman SL, Rollins BY, Birch LL. Parental influence on children's early eating environments and obesity risk: implications for prevention. Int J Obes (Lond)2010 Jul;34(7):1116-24.

7. Arentsen K, Thijs T, Feron F. Early signalizing and preventive management of overweight and obesity in children at risk. Maastricht: Maastricht University; 2009.

8. Arenz S, Ruckerl R, Koletzko B, von Kries R. Breast-feeding and childhood obesity--a systematic review. Int J Obes Relat Metab Disord2004 Oct;28(10):1247-56.

9. Ashby S, James C, Plotnikoff R, Collins C, Guest M, Kable A, et al. Survey of Australian practitioners' provision of healthy lifestyle advice to clients who are obese. Nurs Health Sci2012 Jun;14(2):189-96.

10. Bandura A. Social Foundations of thought and action. A social cognitive theory. Englewood Cliffs, NJ: Prentice-Hall; 1986.

11. Bandura A. Health promotion by social cognitive means. Health Educ Behav2004 Apr;31(2):143-64.

12. Barker DJ. Fetal origins of coronary heart disease. BMJ1995 Jul 15;311(6998):171-4.

13. Barker DJ. In utero programming of cardiovascular disease. Theriogenology2000 Jan 15;53(2):555-74.

14. Barker DJ. Obesity and early life. Obes Rev2007 Mar;8 Suppl 1:45-9.

15. Barker DJ, Winter PD, Osmond C, Margetts B, Simmonds SJ. Weight in infancy and death from ischaemic heart disease. Lancet1989 Sep 9;2(8663):577-80.

16. Bartholomew LK. Intervention Mapping: designing Theory and Evidence based Health Promotion Programs. Health Educ Behav 1998;25:545-63.

17. Bartholomew LK, Parcel GS, Kok G, Gottlieb NH. Planning Health Promotion Programs: An Intervention Mapping Approach, Edition 2. New York: McGraw-Hill Companies; 2006.

18. Benn RT. Some mathematical properties of weight for heigt indices used a measures of adiposity. Br J Prev Soc Med1971;25(1):42-50.

19. Bertotto ML, Valmórbida J, Broilo MC, Campagnolo PDB, Vitolo MR. Association between weight gain in the first year of life with excess weight and abdominal adiposity at preschool age Rev Paul Pediatr2012;30(4):507-12.

20. Black RE, Victora CG, Walker SP, Bhutta ZA, Christian P, de Onis M, et al. Maternal and child undernutrition and overweight in low-income and middle-income countries. Lancet2013 Aug 3;382(9890):427-51.

21. Boere-Boonekamp MM, L'Hoir MP, Beltman M, Bruil J, Dijkstra N, Engelberts AC. Overgewicht en obesitas bij jonge kinderen (0-4 jaar). Ned Tijdschr Geneeskd2008 Feb 9;152(6):324-30.

22. Branca F, Nikogosian H, Lobstein $\mathrm{T}$. The challenge of obesity in the European region and the strategies for response. Copenhagen: World Health Organisation; 2007.

23. Brink-Melis WJ. Preventie overgewicht in de Jeugdgezondheidszorg; gewichtig genoeg?! Utrecht: Universiteit Utrecht; 2009.

24. Brink-Melis WJ, Derksen ER, Westerman MJ, Renders CM, Seidell JC, Visscher TL. The local implementation of a chronic disease management model for childhood overweight and obesity. Obes Facts2012;5(5):766-75. 
25. Broerse A, Kamphuis M, Fleuren MAH, van Dommelen P, Kooijman K, Vergeer M. Van proef naar landelijke implementatie van de JGZ-Richtlijn Secundiare Preventie Kindermishandeling. Dutch Youth Health Care Magazine2010;42:98-100.

26. Brug J, Oenema A, Ferreira I. Theory, evidence and Intervention Mapping to improve behavior nutrition and physical activity interventions. International Journal of Behavioral Nutrition and Physical Activity2005;2(2).

27. Cabana MD, Slish KK, Evans D, Mellins RB, Brown RW, Lin X, et al. Impact of physician asthma care education on patient outcomes. Pediatrics2006 Jun;117(6):2149-57.

28. Campbell K, Engel H, Timperio A, Cooper C, Crawford D. Obesity management: Australian general practitioners' attitudes and practices. Obes Res2000;8(6):459-66.

29. Campbell KJ, Hesketh KD. Strategies which aim to positively impact on weight, physical activity, diet and sedentary behaviors in children from zero to five years. A systematic review of the literature. Obesity Reviews2007;8(4):327-38.

30. Carneiro P, Heckman JJ. Human capital policy. In: Heckmann JJ, Krueger A, editors. Inequality in America: What role for Human Capital Policy? Cambridge MA: MIT Press; 2003. p. 77-240.

31. Carnell S, Edwards C, Croker H, Boniface D, Wardle J. Parental perceptions of overweight in 3-5 y olds. Int J Obes (Lond)2005 Apr;29(4):353-5.

32. Centers for Disease Control and Prevention. Cigarette smoking among adults and trends in smoking cessation - United States, 2008. MMWR Morb Mortal Wkly Rep2009;58(44):1227-32.

33. Cheater F, Baker R, Gillies C, Hearnshaw H, Flottorp S, Robertson N, et al. Tailored interventions to overcome identified barriers to change: effects on professional practice and health care outcomes. Cochrane Database of Systematic Reviews 2005(3):Art. No.: CD005470.

34. Cole TJ, Bellizzi MC, Flegal KM, Dietz WH. Establishing a standard definition for child overweight and obesity worldwide: international survey. BMJ2000 May 6;320(7244):1240-3.

35. Cole TJ, Flegal KM, Nicholls D, Jackson AA. Body mass index cut offs to define thinness in children and adolescents: international survey. BMJ2007 Jul 28;335(7612):194.

36. Dam P. Kosteneffectiviteit van de Jeugdgezondheidszorg. Zoetermeer: Verdonck, Klooster \& Associates B.V.2012.

37. De Kroon M. The Terneuzen Birth Cohort Detection and prevention of overweight and cardiometabolic risk from infancy onward. Amsterdam: University of Amsterdam; 2011.

38. De Kroon M, Renders CM, van Wouwe JP, Hirasing RA, van Buuren S. Identifying young children without overweight at high risk for adult overweight: The Terneuzen Birth Cohort. International Journal of Pediatric Obesity2011;6:e187-e95.

39. De Kroon ML, Renders CM, Buskermolen MP, Van Wouwe JP, van Buuren S, Hirasing RA. The Terneuzen Birth Cohort. Longer exclusive breastfeeding duration is associated with leaner body mass and a healthier diet in young adulthood. BMC Pediatr2011;11:33.

40. De Vries $H$, Mudde A. Predicting stage transitions for smoking cessation applying the attitude -social influence efficacy model. Psychology and Health1998;13:369-85.

41. Dera-de Bie E, Jansen MWJ, Gerver WJ. Inhibiting factors in the prevention of overweight in infants: An explorative study conducted with CHC practitioners in the Netherlands. CHCin Practice2012;18(3):193206.

42. Dera-de Bie, Gerver WJ, Jansen M. Training program for overweight prevention in the child's first year: compilation and results. Nurs Health Sci2013;Sep;15(3):387-97.

43. Dera-de Bie E, Brink-Melis W, Jansen M, Gerver WJ. Characteristics of CHC practitioners in overweight prevention of children. Applied Nursing Research2016: 157-162.

44. Dennisen BA, Edmunds LS, Stratton HH, Pruzek RM. Rapid infant weight gain predicts childhood overweight. Obesity 2006: 14: 491-498.

45. Doak CM, Visscher TL, Renders CM, Seidell JC. The prevention of overweight and obesity in children and adolescents: a review of interventions and program s. Obes Rev2006; Feb;7(1):111-36.

46. Dommelen van P. E-Health Application I-GrowApp. TNO Innovation for Life.

https://www.tno.nl/media/1752/igrowapp.pdf 
47. Doyle O, Harmon CP, Heckman JJ, Tremblay RE. Investing in early human development: timing and economic efficiency. Econ Hum Biol2009 Mar;7(1):1-6.

48. Dunnink G, Lijs-Spek WJG. Activiteiten Basistakenpakket Jeugdgezondheidszorg 0 -19 jaar per Contactmoment. Bilthoven: RIVM2008. Report No.: Rapport 295001001/2008.

49. Dunnink T. Guidelines are not implemented naturally. Dutch Youth Care Magazine2013;45(3):72-3.

50. Ebbeling CB, Pawlak DB, Ludwig DS. Childhood obesity: public-health crisis, common sense cure. Lancet2002 Aug 10;360(9331):473-82.

51. Eckstein KC, Mikhail LM, Ariza AJ, Thomson JS, Millard SC, Binns HJ, et al. Parents' perception of Their Child's Weight and Health. Pediatrics2006;117(3):681-90.

52. Ernst M, Simons M, Jansen MWJ, Zimmerman L, Gerver WJ. The use of a prediction model to prevent abnormal weight in childhood in the Youth Health Care practice. Submitted. [Thesis, Maastricht University, 89-103 ]. 2014.

53. Field A. Discovering Statistics Using SPSS. Third Edition. London: Sage Publications; 2009.

54. Field A. Discovering Statistics Using SPSS. Third Edition. London: Sage Publications; 2013.

55. Finkelstein EA, Graham WC, Malhotra R. Lifetime direct medical costs of childhood obesity. Pediatrics2014 May;133(5):854-62.

56. Fleuren $\mathrm{M}$, de Jong $\mathrm{O}$. Conditions for implementing and continuation of CHCguidelines. Leiden: Organization for Applied Scientific Research (TNO)2006. Report No.: 031.10055/01.01.

57. Fleuren M, Wiefferink K, Paulussen T. Determinants of innovation within health care organizations: : literature review and Delphi study. International Journal for Quality in Health Care2004;16(2):107-23.

58. Fleuren $\mathrm{MAH}$. Essentiële activiteiten en infrastructuur voor de landelijke invoering en monitoring van het gebruik van JGZ-richtlijnen. Leiden: TNO Kwaliteit van Leven; 2010.

59. Fleuren MAH, de Jong ORW. Basisvoorwaarden voor implementatie en borging van de standaarden Jeugdgezondheidszorg. Leiden: TNO2006.

60.. Fleuren MAH, Kamphuis M. Opsporing van Visuele Stoornissen 0-18 jaar. Implementatie JGZ standaard geëvalueerd. Leiden: TNO, Netherlands Organization of Applied Scientific Research; 2006.

61. Fleuren MAH, Paulussen TGWM, Dommelen van $P$, Buuren van S. Towards a measurement instrumentfor determinants of innovations. International Journal for Quality in Health Care. 2014 June;26(5):501510.

62. Franks PW, Hanson RL, Knowler WC, Sievers ML, Bennett PH, Looker HC. Childhood Obesity, Other Cardiovascular Risk Factors, and Premature Death. N Engl J Med2010;362:485-93.

63. Fransen GA, Hiddink GJ, Koelen MA, van Dis SJ, Drenthen AJ, van Binsbergen JJ, et al. The development of a minimal intervention strategy to address overweight and obesity in adult primary care patients in The Netherlands. Fam Pract2008 Dec;25 Suppl 1:i112-5.

64. Frederiks AM, Van Buuren S, Sing RA, Wit JM, Verloove-Vanhorick SP. Alarming prevalences of overweight and obesity for children of Turkish, Morroccan and Dutch origin in the Netherlands according to international standards. Acta Pediatr2005;94(4):496-8.

65. Frederiks AM, van Buuren $\mathrm{S}$, et al. Are age references for waist circumference, hip circumference and waist -hip ratio in Dutch children useful in clinical practice ? Eur J Pediatr.2005 Apr;164 (4):216-22.

66. Freedman DS, Khan LK, Dietz WH, Srinivasan SR, Berenson GS. Relationship of childhood obesity to coronary heart disease risk factors in adulthood: the Bogalusa Heart Study. Pediatrics2001 Sep;108(3):712-8.

67. Gerards SM, Sleddens EF, Dagnelie PC, de Vries NK, Kremers SP. Interventions addressing general parenting to prevent or treat childhood obesity. Int J Pediatr Obes2011 Jun;6(2-2):e28-45.

68. Gerver WJM, De Bruin R. Paediatric Morphometrics, A reference manual.( second extended edition). University Press Maastricht, The Netherlands, ISBN 905278307 1;2001.

69. Green LW. Making research relevant: if it is an evidence-based practice, where's the practice based evidence ? Family Practice2008;25:i20-i24.

70. Gluckman PD, Hanson MA. Developmental origins of disease paradigm: a mechanistic and evolutionary perspective. Pediatr Res2004 Sep;56(3):311-7. 
71. Gluckmann PD, Hanson MA, Cooper C, Thornburg KL. Effect of In Utero and Early-Life Conditions on Adult Health and Disease. N Engl J Med2008;359(61-73).

72. Goossens A, Bossuyt PM, de Haan RJ. Physicians and nurses focus on different aspects of guidelines when deciding whether to adopt them: an application of conjoint analysis. Med Decis Making2008 JanFeb;28(1):138-45.

73. Graitcer PL, Gentry EM. Measuring children: one reference for all. Lancet1981;2(8241):297-9.

74. Grol R. Successes and Failures in the Implementation of Evidence-Based Guidelines for Clinical Practice. Medical Care2001;39(8 suppl.2):1146-54.

75. Grunert KG, Wills JM, Fernandez-Celemin. Nutrition knowledge, and use and understanding of nutrition information on food labels among consumers in the UK. Appetite2010;55:177-189.

76. Grundy SM. Arteriosclerosis, Thrombosis and Vascular Biology. Metabolic Syndrome Pandemic. Brief Review2008;28:629-36.

77. Haines A, Donald A. Making better use of research findings. British Medical Journal1998;317(7150):72-5.

78. Hales CN, Barker DJ. The thrifty phenotype hypothesis. Br Med Bull2001;60:5-20.

79. Harmsen $M$, Peters $M$, Wensing $M$. Barriers and facilitators. Assessment Instrument: Introduction, Instruction and Instrument. Nijmegen: IQ healthcare; 2005.

80. Hash RB, Munna RK, Vogel RL, Bason JJ. Does physician weight affect perception of health advice? . Preventive Medicine2003;36(1):41-4.

81. Hattersley DM, Tooke JE. The fetal insulin hypothesis: an alternative explanation of low birth weight with diabetes and vascular disease. The Lancet1999;53(9166):1789-92.

82. Haynos AF, O'Donohue WT. Universal childhood and adolescent obesity prevention programs: review and critical analysis. Clin Psychol Rev2012 Jul;32(5):383-99.

83. Hearn LA, Miller MR, Campbell-Pope R. Review of evidence to guide primary health care policy and practice to prevent childhood obesity. Med J Aust2008 Apr 21;188(8 Suppl):S87-91.

84. Hediger ML, Overpeck MD, Kuczmarski RJ, Ruan WJ. Association between infant breastfeeding and overweight in young children. JAMA2001 May 16;285(19):2453-60.

85. Hesketh KD, Campbell KJ. Interventions to prevent Obesity in 0-5 years Olds: An updated Systematic Review of the Literature. Obesity2010 Feb;18 (S1):S27-S35.

86. Hester SN, Hustead DS, Mackey AD, Singhal A, Marriage BJ. Is the macronutrient intake of formula -fed infants greater than breast -fed infants in early infancy ? J Nutr metab 2012;891201.

87. Jansen W, Brug J. Parents often do not recognize overweight in their child, regardless of their sociodemographic background. European Journal of Public Health2006;16(6):645-7.

88. Kelder SH, Perry CL, Klepp KI, Lytle LL. Longitudinal tracking of adolescent smoking, physical activity, and food choice behaviors. Am J Public Health1994 Jul;84(7):1121-6.

89. Kohl HW, 3rd, Craig CL, Lambert EV, Inoue S, Alkandari JR, Leetongin G, et al. The pandemic of physical inactivity: global action for public health. Lancet2012 Jul 21;380(9838):294-305.

90. Lake JK, Power C, Cole TJ. Child to adult body mass index in the 1958 British birth cohort: associations with parental obesity. Arch Dis Child1997 Nov;77(5):376-81.

91.. L'Allemand-Jander D. Clinical diagnosis of metabolic and cardiovasculair risks in overweight children: early development of chronic diseases in the obese child. International Journal of Obesity2010;34:S32S6.

92. Lobstein T, Baur L, Uauy R. Obesity in children and young people: a crisis in public health. Obes Rev2004 May; 5 Suppl 1:4-104.

93. Lumley J, Chamberlain C, Dowswell T, Oliver S, Oakley L, Watson L. Interventions for promoting smoking cessation during pregnancy. Cochrane Database Syst Rev2009(3):CD001055.

94. Martens C. Dutch Heart Foundation. Public Affairs via c.martens@ hartstichting.nl https://www.hartstichting.nl/downloads/infosheet-onderzoek-kidsmarketing.2015

95. Mesman I, Roseboom TJ, Bonsel GJ, Gemke RJ, van der Wal MF, Vrijkotte TG. Maternal pre-pregnancy body mass index explains infant's weight and BMI at 14 months: results from a multi-ethnic birth cohort study. Arch Dis Child2009 Aug;94(8):587-95. 
96. Mikhailovich K, Morrison P. Discussing childhood overweight and obesity with parents: a health communication dilemma. J CHC2007 Dec;11(4):311-22.

97. Miller WR, Rollnick S. Motivational Interviewing: Preparing people for change (second edition). New York: Guildford Press; 2002.

98. National Institute for Public Health and the Environment. RIVM. Ministry of Health, Welfare and Sports. Dutch National Food Consumption Survey. 2015. http://www.rivm.nl/en/Topics/D/Dutch_National_Food_Consumption_Survey

99. O'Callaghan MJ, Williams GM, Andersen MJ, Bor W, Najman JM. Prediction of obesity in children at 5 years: a cohort study. Journal of Paediatrics and Child Health 1997;33(4):311-6.

100.. Ong KK, Loos RJ. Rapid infancy weight gain and subsequent obesity: systematic reviews and hopeful suggestions. Acta Paediatr2006 Aug;95(8):904-8.

101. Pampel FC, Krueger PM, Denney JT. Socioeconomic Disparities in Health Behaviors. Annu Rev Sociol2010 Aug;36:349-70.

102. Parry LL, Netuveli G, Parry J, Saxena S. A systematic review of Parental Perceptions of Overweight Status in Children. Journal of Ambulatory Care Management2008;31(3):253-68.

103. Paulussen T, Wiefferink K, Mesters I. Invoering van effectief gebleken interventies. In: Brug J, van Assema P, Lechner L, editors. Gezondheidsvoorlichting en gedragsverandering. Assen: Koninklijke Van Gorcum; 2007.

104. Paulussen TGW. Adoption and implementation of AIDS education in Dutch secondary schools. Utrecht: Dutch Center for Health Promotion and Health Education; 1994.

105. Paulussen THGW. Antecedents to adoption of class-room based AIDS education in Dutch secondary schools. Health Education Research1994;9:485-96.

106. Petty R, Cacioppo JT. Communication and persuasion: Central and peripheral routes to attitude change. New York: Springer Verlag; 1986.

107. Pollestad Kolsgaard ML, Frost Andersen F, Tonstad S, Brunborg C, Wangensteen T, Joner G. Ethnic differences in metabolic syndrome among overweight and obese children and adolescents: the Oslo Adiposity Intervention Study. Acta Pediatr2008;97:1557-63.

108. Reilly JJ, Armstrong J, Dorosty AR, Emmett PM, Ness A, Rogers I, et al. Early life risk factors for obesity in childhood: cohort study. BMJ2005 Jun 11;330(7504):1357.

109. Reilly JJ, Kelly J. Long-term impact of overweight and obesity in childhood and adolescence on morbidity and premature mortality in adulthood: systematic review. Int J Obes (Lond)2011 Jul;35(7):891-8.

110. Reilly JJ, Methven E, McDowell ZC, Hacking B, Alexander D, Stewart L, et al. Health consequences of obesity. Arch Dis Child2003 Sep;88(9):748-52.

111. Roskam AJ, Kunst AE. The predictive value of different socioeconomic indicators for overweight in nine European countries. Public Health Nutr2008 Dec;11(12):1256-66.

112. Savage JS, Fisher JO, Birch LL. Parental influence on eating behavior: conception to adolescence. J Law Med Ethics2007;35(1):22-34.

113. Scaglioni S, Arrizza C, Vecchi F, Tedeschi S. Determinants of children's eating behavior. American Journal of Clinical Nutrition2011;94(6 suppl):2006S-11S.

114. Schefske SD, Bellows AC, Byrd-Bredbenner C, Cuite CL, Rapport H, Vivar T, et al. Nutrient analysis of varying socioeconomic status home food environments in New Jersey. Appetite2010 Apr;54(2):384-9.

115. Schokker DF, Visscher TL, Nooyens AC, van Baak MA, Seidell JC. Prevalence of overweight and obesity in the Netherlands. Obes Rev2007 Mar;8(2):101-8.

116. Schönbeck Y, Talma H, van Dommelen P, Bakker B, Buitendijk SE, Hirasing RA, et al. Increase in prevalence of overweight in Dutch children and adolescents: a comparison of nationwide growth studies in 1980, 1997 and 2009. PLoS One2011;6(11):e27608.

117. Schönbeck Y, van Buuren S. Factsheet Resultaten Vijfde Landelijke Groeistudie. Leiden: TNO2010.

118. Schuller A. Detaildocument over effecten jeugdgezondheidszorg. Versie 3.20. Bilthoven: RIVM; 2006 [updated december 2009]. 
119. Schwartz RP, Hamre R, Dietz WH, Wasserman RC, Slora EJ, Myers EF, et al. Office-based motivational interviewing to prevent childhood obesity: a feasibility study. Arch Pediatr Adolesc Med2007 May;161(5):495-501.

120. Seidell JC, Halberstadt J. The global burden of obesity and the challenges of prevention. Ann Nutr Metab2015;66 Suppl 2:7-12.

121. Singh AS, Mulder C, Twisk JW, van Mechelen W, Chinapaw MJ. Tracking of childhood overweight into adulthood: a systematic review of the literature. Obes Rev2008 Sep;9(5):474-88.

122. Smith J. The contribution of infant food marketing to the obesegenic environment in Australia. Breastfeeding review 2007 Mar 15 (1);23-35.

123. Smith SM, Gately P, Rudolf M. Can we recognise obesity clinically? Archives of Disease in Childhood2008;93(12):1065-6.

124. Spivack JG, Swietlik M, Alessandrini E, Faith MS. Primary care providers' knowledge, practices, and perceived barriers to the treatment and prevention of childhood obesity. Obesity (Silver Spring)2010 Jul;18(7):1341-7.

125. Stolzer JM. Breastfeeding and obesity: a meta-analysis Open Journal of Preventive Medicine 2011;1(3):88-93.

126. Story MT, Neumark-Stzainer DR, Sherwood NE, Holt K, Sofka D, Trowbridge FL, et al. Management of child and adolescent obesity: attitudes, barriers, skills, and training needs among health care professionals. Pediatrics2002 Jul;110(1 Pt 2):210-4.

127. Touwslager RN, Gielen M, Mulder AL, Gerver WJ, Zimmermann L, Fowler T, et al. Changes in genetic and environmental effects on growth during infancy. Am J Clin Nutr2011 Dec;94(6):1568-74.

128. van den Berg M, Schrijvers CTM. Preventie gericht op jeugd: Wat is het bereik en wat zijn de effecten? Bilthoven: RIVM; 2007; Available from: http://www.nationaalkompas.nl/preventie/gericht-opdoelgroepen/jeugd/bereik-effecten/.

129. van den Hurk K, van Dommelen P, van Buuren S, Verkerk PH, Hirasing RA. Prevalence of overweight and obesity in the Netherlands in 2003 compared to 1980 and 1997. Arch Dis Child2007 Nov;92(11):992-5.

130. van Duin C, de Jong G, Stoeldraijer L, Garssen J. Bevolkingsprognose 2010-2060: model en veronderstellingen betreffende de sterfte. Den Haag/Heerlen: Centraal Bureau voor de Statistiek2011 25 maart.

131. Veldhuis L, Struijk MK, Kroeze W, Oenema A, Renders CM, Bulk-Bunschoten AM, et al. 'Be active, eat right', evaluation of an overweight prevention protocol among 5-year-old children: design of a cluster randomised controlled trial. BMC Public Health2009;9:177.

132. Wang Y, Beydoun MA. The Obesity Epidemic in the United States-Gender, Age, Socioeconomic, Racial/Ethnic, and Geographic Characteristics; A Systematic Review and Meta -Regression Analysis. Epidemiol Rev2007;29(1):6-28

133. Weinstein ND, Sandman PM, Blalock SJ. The Precaution Adoption Process Model. In: Glanz K, Rimer BK, Viswanath K, editors. Health Behavior and Health Education Theory, Research, and Practice. San Francisco: Jossey-Bass; 2002.

134. Weiss R, Dziura J, Burgert TS, Tamborlane WV, Taksali SE, Yeckel CW, et al. Obesity and the metabolic syndrome in children and adolescents. N Engl J Med2004 Jun 3;350(23):2362-74.

135. Wieringen J, Wieren S. Nationaal Kompas Volksgezondheid. Bilthoven: RIVM; 2010.

136. Williams J, Wake M, Hesketh K, Maher E, Waters E. Health-Related Quality of Life of Overweight and Obese Children. JAMA2005;293(1):70-6.

137. World Health Organisation. Obesity: preventing and managing the global epidemic. Geneva: WHO2O0O. Report No.: WHO Technical Report Series 894.

138. World Health Organisation. Healthy diet. Fact sheet N³94. 2015 [updated May 2015].

139. World Health Organisation. Obesity and overweight. Fact sheet N³11. 2015 [updated January 2015]. 


\section{CHAPTER 8}

Summary /samenvatting 


\section{SUMMARY}

Overweight is an important contributor to life-long negative health consequences, such as the metabolic syndrome or even premature mortality. It is known that early childhood is a critical period for assessing the origins of overweight in adulthood. Moreover, once a child is overweight it is difficult to reduce its weight to an ideal level. It is therefore important to start overweight prevention from birth onward.

The prevalence rates of overweight children in the Netherlands almost tripled between 1980 and 2009, and have now reached a level of 13-15\% of all children aged 221 years. The problem of overweight children has to be addressed by child health care ( $\mathrm{CHC}$ ) physicians and nurses. The Dutch $\mathrm{CHC}$ services have acknowledged that they have a task in early overweight prevention, and an overweight prevention protocol was developed in 2005. This protocol describes the assessments to detect overweight children and also includes recommendations for a healthy lifestyle. Yet, at the time this PhD project was started, information obtained from the literature and practitioners suggested that the overweight prevention protocol was insufficiently used in $\mathrm{CHC}$ practice. Also, there was a lack of knowledge about the effectiveness of the protocol.

Research has shown that many protocols are designed and implemented without considering how they can be integrated in daily practice. Often an effective training program is necessary to support practitioners in their use. In addition, improving the efficacy of overweight prevention requires more information regarding current practices at the CHC services, and the content of consultations with the parents. In the research project reported on in this thesis we investigated if a more active implementation strategy for the overweight prevention protocol could improve its use in daily practice by $\mathrm{CHC}$ physicians and nurses. We also examined the effect on the course of children's weight in the first two years of life, to see whether the development of overweight could be prevented.

Chapter 1 provides an extensive general introduction to the background of this PhD project. The first aim of this project was to investigate the inhibiting factors experienced by $\mathrm{CHC}$ physicians and nurses with respect to early overweight prevention in their daily $\mathrm{CHC}$ practice, explored by means of a qualitative study. Twelve in-depth interviews with $\mathrm{CHC}$ physicians and nurses working in $\mathrm{CHC}$ organizations in the Southern Limburg region of the Netherlands were conducted, using a semi-structured topic list. Chapter 2 presents the results of this qualitative study. The overall results indicate that $\mathrm{CHC}$ practitioners were insufficiently aware that a child's first year of life is an important period for the prevention of overweight, and that the $\mathrm{CHC}$ practitioners found it difficult to discuss the topic of overweight with parents, especially when the parents were unmotivated. The study also confirmed that $\mathrm{CHC}$ physicians and nurses used the overweight prevention protocol inadequately in their daily $\mathrm{CHC}$ practice.

Chapter 3 reports on a qualitative study investigating the barriers encountered by $\mathrm{CHC}$ practitioners, as well as organizational preconditions with respect to the use of the 
overweight prevention protocol in $\mathrm{CHC}$ practice. For this study a self-report questionnaire was developed with five main categories, namely (1) awareness of the importance of prevention; (2) discussing overweight with parents; (3) adherence to a systematic approach for implementing the overweight protocol; (4) supportive factors within the organization and (5) personal characteristics. This study was conducted among nine different regional $\mathrm{CHC}$ organizations in the Netherlands. In total, 69 physicians and 147 nurses completed the questionnaire. The results showed that the focus of overweight prevention by $\mathrm{CHC}$ physicians and nurses was clearly less on children in their first year. The study also showed that there is a gap between the awareness of the importance of overweight prevention and actually discussing the risk of developing overweight with parents. Furthermore, the results revealed a gap between the existing recommendations and the perceived importance of early overweight prevention.

In addition, this study made it clear that the nurses needed more support than the physicians as regards knowledge about the importance of overweight prevention starting form birth onward, as well as for skills to discuss overweight (or the risk thereof) with parents. Summarizing, from the results described in Chapter 2 and Chapter 3 it became clear that there was a need to improve the prevention of overweight among very young children, including those who are not yet overweight.

Based on the results of the study, a training program for Dutch $\mathrm{CHC}$ practitioners was developed to improve the implementation of the overweight prevention protocol. The development and design of this training program are described in Chapter 4. The Intervention Mapping (IM) framework, which is based on a combination of theoretical evidence and practical information, was used to structure the path of the development and implementation of this tailored training program for $\mathrm{CHC}$ practitioners. The training program was evaluated in terms of process and effect.

The effectiveness of the training program was assessed using a quasi-experimental design with intervention and control group. A self-report questionnaire was completed at baseline and one-year follow-up. The results of this evaluation showed greater improvements in the intervention group than in the control group regarding (1) the awareness that overweight prevention should already start in a child's first year, (2) knowledge about the overweight protocol and how to use it in practice and (3) the difficulty of discussing overweight (or the risk thereof) with parents.

Chapter five presents the results of a more active implementation of the overweight prevention protocol and how this affects the course of children's weight form birth until the age of two. The study compared three growth cohorts of children. All 1333 participants were born in the Southern Limburg region of the Netherlands. No differences were found between the three cohorts in terms of the anthropometric measures of weight, height, weight SDS, height SDS and BMI.

Finally, Chapter six addresses the main findings of this thesis, discussing the results in terms of early overweight prevention and their relevance for $\mathrm{CHC}$ practice. The chapter also provides some recommendations for practice and future research. The follow- 
ing overall conclusions are drawn. First, a good measurement tool to detect children at risk for overweight in the period from birth until the age of two years may be useful for $\mathrm{CHC}$ practitioners. Secondly, there is a need to improve the communication skills of $\mathrm{CHC}$ practitioners when a child is at risk for overweight, and motivating and supporting parents is important in this respect. Therefore $\mathrm{CHC}$ practitioners need to be trained in individual counseling on a regular and continuous basis.

Tackling the problem of overweight and obesity will be a challenge for the coming decades. The problem has evolved since the 1960s and it will take decades to solve or ameliorate. Social and cultural changes have pervaded our lives, with disastrous impacts, increasing the level of physical inactivity and sedentary behavior and the consumption of highly processed and unhealthy food. The impact of the "unhealthy" food industry affects children from birth onward, and their parents are tempted to provide them with soft drinks and highly caloric unhealthy foods. Stricter rules for marketing aimed at young children and their parents should be seriously considered. A more interdisciplinary preventive approach seems necessary to tackle the problem of overweight children. $\mathrm{CHC}$ practitioners can contribute to this by advocating healthy lifestyle policies for babies and children, including the provision of healthy food at daycare centers or schools. 


\section{SAMENVATTING}

Overgewicht heeft gedurende de hele levensloop een negatief effect op de gezondheid van kind of volwassene, door o.a. een verhoogd risico op het verkrijgen van het metabool syndroom of een verminderde levensverwachting. Het is bekend dat de vroege zuigelingenperiode een belangrijke levensfase is voor het ontwikkelen van overgewicht op latere leeftijd. Indien een kind eenmaal overgewicht heeft, dan is het moeilijk om weer een normaal gewicht te verkrijgen. Preventie van overgewicht vanaf de geboorte van het kind is om deze redenen belangrijk.

In Nederland is de prevalentie van overgewicht bij kinderen bijna verdriedubbeld sinds 1980, in 2009 had circa 13\% -15\% van de kinderen in de leeftijdsperiode 2-21 jaar overgewicht. Binnen de jeugdgezondheidszorg hebben de jeugdartsen en jeugdverpleegkundigen in de dagelijkse praktijk te maken met overgewicht bij kinderen.

De Nederlandse jeugdgezondheidszorg (JGZ) organisatie heeft erkend dat zij een taak heeft in de preventie van overgewicht bij kinderen en om deze reden is er in 2005 een overgewicht preventieprotocol ontwikkeld. In dit protocol worden de criteria en de wijze van meten beschreven om te kunnen signaleren of een kind overgewicht heeft. Ook staan er adviezen in voor een gezondere leefstijl. Echter, bij de start van deze studie bleek uit literatuur en uit praktijkervaringen dat het overgewicht preventieprotocol niet correct werd toegepast in de praktijk van de jeugdgezondheidszorg. Bovendien was er een gebrek aan kennis over de effectiviteit van dit overgewicht preventie protocol.

Het is een bekend gegeven vanuit literatuur dat er veel protocollen worden ontwikkeld en geïmplementeerd zonder een goede aansluiting in de dagelijkse praktijk.

Vaak is een effectief trainingsprogramma nodig om professionals te ondersteunen in de toepassing van een nieuw protocol. Het verbeteren van de effectiviteit van preventie van overgewicht vraagt om meer inzicht in de huidige dagelijkse praktijk van de JGZ en om meer inzicht in de inhoud van de consultatie tussen JGZ professionals en ouders.

In dit proefschrift is onderzocht of een meer actieve implementatiestrategie van het overgewicht preventieprotocol bijdraagt aan een betere toepassing ervan in de dagelijkse JGZ praktijk. Ook werd getracht door deze studie meer inzicht te verkrijgen in het verloop van het gewicht van kinderen in de leeftijdscategorie 0 tot 2 jaar, dit gerelateerd aan vroegtijdige preventie van overgewicht. In hoofdstuk 1 wordt een uitgebreidere achtergrond van dit proefschrift beschreven.

Het eerste doel van dit proefschrift was het onderzoek doen naar de belemmeringen die jeugdartsen en jeugdverpleegkundigen ervaren bij de uitvoering van preventie van overgewicht in de dagelijkse JGZ praktijk. Om inzicht te krijgen in deze belemmerende factoren is er een exploratief kwalitatief onderzoek gedaan. Er zijn in totaal twaalf jeugdartsen of jeugdverpleegkundigen geïnterviewd door middel van een voor gestructureerde vragenlijst. Alle geïnterviewde deelnemers waren werkzaam bij een JGZ organisatie in Zuid Limburg, In hoofdstuk 2 worden de resultaten van deze kwalitatieve stu- 
die beschreven. De resultaten laten zien dat de JGZ professionals zich onvoldoende bewust zijn dat het eerste levensjaar van het kind een belangrijke periode is in de preventie van overgewicht en dat ze het bespreken van het onderwerp met ouders als moeilijk ervaren met name wanneer ze weerstand of motivatiegebrek bij ouders ervaren. Eveneens werd door deze studie bevestigd dat het overgewicht preventieprotocol inadequaat in de JGZ praktijk wordt toegepast.

Hoofdstuk 3 beschrijft een kwantitatieve studie, waarin onderzocht is wat de ervaren belemmeringen zijn bij de JGZ professionals en wat de benodigde organisatorische voorwaarden zijn in relatie tot de toepassing van het overgewicht preventieprotocol in de JGZ praktijk. Om dit te meten is er voor deze studie een zelf gerapporteerde vragenlijst ontwikkeld. Deze vragenlijst bestaat uit de volgende vijf hoofdcategorieën; (1) bewust zijn van het belang van vroegtijdige preventie bij overgewicht, (2) het bespreken van het onderwerp overgewicht met de ouder(s), (3) naleving van het op een systematische wijze toepassen van het overgewicht preventieprotocol, (4) ondersteunende factoren vanuit de organisatie (5) en persoonlijke kenmerken.

Deze studie is uitgevoerd bij JGZ organisaties, verdeeld over negen verschillende regio's in Nederland. In totaal hebben 69 jeugdartsen en 147 jeugdverpleegkundigen de vragenlijst ingevuld. De studie liet zien dat er nog een brug te slaan is tussen het bewust zijn van het belang van vroegtijdige preventie van overgewicht en het daadwerkelijk bespreken met de ouders wanneer het kind een risico heeft op het ontstaan overgewicht. Ook laat deze studie zien dat er nog een groot verschil bestaat tussen de bestaande aanbevelingen en het ervaren van het belang van vroegtijdige preventie van overgewicht. Verder, blijkt dat de jeugdverpleegkundigen meer ondersteuning nodig hebben dan de jeugdartsen wat betreft kennis over het belang van preventie van overgewicht vanaf de geboorte. Ze hebben vooral meer ondersteuning nodig als het gaat om communicatie vaardigheden om met ouders het risico op het ontstaan van overgewicht bij hun kind te bespreken. Samenvattend, blijkt uit hoofdstuk 2 en hoofdstuk 3 dat er een noodzaak is om de preventie van overgewicht bij de zeer jonge kinderen te verbeteren, zelfs als er nog geen sprake is van overgewicht.

Gebaseerd op de resultaten van voorgaande hoofdstukken is er een trainingsprogramma ontwikkeld voor de JGZ professionals om de implementatie en getrouwe toepassing van het overgewicht preventieprotocol te verbeteren. De ontwikkeling en ontwerp van dit trainingsprogramma is beschreven in hoofdstuk 4. Het Intervention Mapping (IM) model is gebruikt voor de planning en ontwikkeling van een op maat ontwikkeld trainingsprogramma voor de JGZ professionals. De IM methode is gebaseerd op een combinatie van theoretische onderliggende gezondheidsmodellen en praktische informatie. Na uitvoer is het ontwikkelde trainingsprogramma geëvalueerd op zowel proces als op effect. Er is een quasi experimenteel onderzoek uitgevoerd, waarbij een interventiegroep wordt vergeleken met twee controlegroepen, dit om de effectiviteit van het trainingsprogramma inzichtelijk te maken. Om het effect te meten is er gebruik gemaakt 
van de zelf gerapporteerde vragenlijst en deze is aan het begin van de training en een jaar later door de deelnemende jeugdartsen en jeugdverpleegkundigen ingevuld. De interventie groep liet meer positieve resultaten zien dan de controlegroepen wat betreft de volgende items: (1) het bewust ervan zijn dat preventie van overgewicht al in het eerst levensjaar van het kind belangrijk is, (2) kennis over het overgewicht preventieprotocol en hoe dit te gebruiken in de dagelijkse JGZ praktijk en (3) het minder moeilijk vinden om het onderwerp overgewicht te bespreken met ouders.

In hoofdstuk 5 worden de resultaten beschreven van het effect van een meer actieve implementatie strategie van het overgewicht preventieprotocol op de groeilijn van een kind in de leeftijd van 0 tot 2 jaar. Voor deze studie zijn er drie groeicohorten van kinderen met elkaar vergeleken, Alle 1333 deelnemende kinderen zijn geboren in de regio Zuid Limburg, De resultaten van deze studie laten zien dat er geen verschil is tussen de drie cohorten wat betreft de antropometrische waarden gewicht, lengte, gewicht SDS, Lengte SDS en de Body Mass Index (BMI).

Tenslotte wordt in hoofdstuk 6 de belangrijkste bevindingen van dit proefschrift beschreven. In dit hoofdstuk zijn de resultaten bediscussieerd in een bredere context met daarbij de focus op vroegtijdige preventie van overgewicht en de relevantie ervan voor de JGZ. Ook een aantal aanbevelingen voor zowel de praktijk als voor toekomstig onderzoek worden benoemd in dit laatste hoofdstuk. Tevens worden de conclusies van dit proefschrift worden benoemd.

Een eerste conclusie is dat een goed adequaat meetinstrument om vroegtijdig te signaleren of een kind in de leeftijd van 0 tot 2 jaar risico heeft op het ontstaan van overgewicht JGZ professionals kan ondersteunen in hun preventieve taak.

Een tweede conclusie is een noodzaak in het verbeteren van communicatie vaardigheden bij JGZ professionals indien het gaat om het bespreken van een risico op overgewicht bij een kind met daarbij ook aandacht voor het motiveren en ondersteunen van ouders. Om deze redenen is het aan te bevelen om JGZ professionals structureel te trainen in individuele counseling vaardigheden als het gaat om communicatie over gezondheid risico's.

Als laatste, de aanpak van het probleem van overgewicht en obesitas is een uitdaging voor de komende decennia 's. Het probleem heeft zich ontwikkeld sinds de jaren zestig van de 20 ste eeuw en het zal nog decennia duren eer het probleem is opgelost of gereduceerd. Enkele sociale en culturele veranderingen zijn in het leven geïntegreerd met soms een desastreus effect. Zo is er een afname van fysieke activiteit, inactief gedrag, en er is een ongezonde voedingsconsumptie maatschappij ontstaan. De voedingsindustrie probeert "ongezonde voeding " aan te prijzen al vanaf de geboorte van het kind en ouders worden verleid tot het gebruik van ongezonde voedingsproducten. Strengere regels voor marketing gericht op jonge kinderen en hun ouders zou serieus in overweging dienen te worden genomen. Een meer collectieve en preventieve aanpak lijkt nodig te zijn om het probleem van overgewicht bij kinderen aan te pakken. 
JGZ professionals kunnen bijdragen aan de preventie van overgewicht door o.a. beleidsadvies te geven over een gezonde leefstijl voor baby's en kinderen, zoals gezonde voeding en voldoende beweging bij kinderopvang of bij scholen. 
Valorisation of the research findings 


\section{VALORISEREN VAN HET ONDERZOEK}

Dikwijls is er een discussie in hoeverre wetenschappelijk onderzoek van toepassing is op de dagelijkse praktijk. Vaak duurt het jaren voordat wetenschappelijk onderzoek in de praktijk wordt toegepast en soms verdwijnt het zelfs in een buro lade. Niettemin is een van de doelstellingen van wetenschappelijk onderzoek dat de resultaten van toepassing zijn of een nuttige bijdrage leveren aan de algemene praktijk. Daarvan is zeker sprake wanneer het gaat om gezondheidsproblematiek.

Dit onderzoek is gestart vanuit de Academische Werkplaats Zuid Limburg, die overgewicht en obesitas als een bedreiging van gezondheid probeert aan te pakken. In dit onderzoek is een vraag vanuit de praktijk vertaald naar een wetenschappelijke onderzoeksvraag om zo meer inzicht te verkrijgen in dit hardnekkig maatschappelijk probleem.

Een van de doelstellingen van de jeugdgezondheidszorg is om overgewicht bij kinderen te voorkomen vanwege de daaraan gerelateerde gezondheidsrisico's op latere leeftijd, waaronder het metabool syndroom, de voorspeller van hart en vaatziekten. Vroegtijdige signalering speelt daarbij een essentiële rol. Dit onderzoek heeft bijgedragen aan het bewuster maken van professionals en ouders dat het eerste levensjaar van het kind een belangrijke periode is in de preventie van overgewicht.

Uit het onderzoek wordt het belang van het volgen van de groeicurve van een kind duidelijk. De groeicurve is een eerste evidence -based basisinstrument om vroegtijdig veranderingen of afwijkingen te signaleren.

Voor kinderen onder de twee jaar wordt de gewicht naar lengte curve gehanteerd om te bepalen of een kind risico heeft op overgewicht. Echter, uit dit onderzoek blijkt dat het voor de jeugdartsen en jeugdverpleegkundigen moeilijk is om afwijkende groei in de eerste twee levensjaren van het kind op een juiste wijze te interpreteren. Met name is er een probleem wanneer het verloop van de curve weliswaar afwijkend is, maar de absolute maat nog binnen de norm valt. Een meetinstrument om het ontwikkelen van overgewicht te voorspellen zou professionals hierin kunnen ondersteunen.

Begeleiding van kinderen met risico op overgewicht is een van de taken van de jeugdgezondheidszorg. De jeugdgezondheidszorg nodigt niet alleen ouders met kinderen uit voor consultatie op een vaste locatie, maar bezoekt de ouder en kind ook aan huis. De waarde van huisbezoeken, waardoor meer en betere informatie wordt verkregen over de directe omgeving van een kind, staat buiten discussie. In dit onderzoek werden de effecten van die aandacht voor de directe omgeving van kind en ouders geëvalueerd. Hoewel de resultaten niet direct meetbaar waren, volgt uit ons onderzoek wel degelijk dat deze benadering van groot belang is. Dit onderzoek is een basis waarop verder on- 
derzoek kan worden verricht zodanig dat het effect duidelijker zichtbaar wordt. Met name blijkt dat het inzicht en motivatie bij de ouders nog te kort schiet, hoewel de kennis en motivatie bij de hulpverlener wel is toegenomen.

In het kader van dit onderzoek hebben er een aantal deskundigheid bevorderende activiteiten plaatsgevonden voor jeugdartsen en jeugdverpleegkundigen, waaronder een training motivational interviewing, casuïstiek besprekingen en visitaties. Doel van deze activiteiten was om de hulpverleners middelen aan te reiken om dreigend overgewicht eerder te signaleren en bespreekbaar te maken met de ouders.

Ook werd door het onderzoek inzichtelijk dat de kennis en vaardigheden van de jeugdartsen beter was dan dat van de jeugdverpleegkundigen. Voor de jeugdartsen zijn de deskundigheidsbevorderingen beter gefaciliteerd en vastgelegd. Extra aandacht voor jeugdverpleegkundige competenties, waaronder gesprekstechnieken is belangrijk, aangezien zij degenen zijn die met name de laagdrempelige kortdurende begeleiding doen. Dit onderzoek heeft aangetoond dat door de deskundigheid bevorderende activiteiten bijgedragen is aan een kwaliteitsverbetering in de uitvoering van preventie van overgewicht.

Doordat de onderzoeker ook zelf werkzaam is in de jeugdgezondheidszorg kon het onderzoek beter afgestemd worden op de behoeften van de praktijk en de betrokkenheid van de deelnemers aan het onderzoek werd ermee vergroot. Medewerking aan onderzoek vanuit de praktijk vraagt extra tijd van uitvoerenden en de organisatie realiseert zich dit soms onvoldoende. Verder, heeft dit onderzoek bijgedragen aan ondersteunende beleidsinformatie.

Uit het onderzoek blijkt hoe moeilijk het is om een ongezonde leefstijl in een gezin te veranderen naar een gezondere leefstijl, zeker bij bepaalde risicogroepen. Preventie van overgewicht is een taak van verschillende partners in de zorgketen. Door de uitvoering van dit onderzoek werd ook duidelijk dat samenwerking, afstemming en het overbruggen van de culturen van de verschillende organisaties belangrijk is om het probleem van overgewicht bij kinderen aan te pakken.

Gedurende de periode van het onderzoek zijn er diverse activiteiten geweest om het onderzoek onder de aandacht te brengen. Zo zijn er presentaties geweest op congressen (o.a. EUSSUHM congres) of zijn er artikelen geschreven voor nieuwsbrieven. Verder is er een nauwe samenwerking geweest met peuterspeelzalen en kinderopvang en is er mede zorg gedragen voor verandering in traktatiebeleid en voedingsbeleid.

Dit onderzoek geeft een inventarisatie van knelpunten, een implementatie strategie en een proces en effect evaluatie voor de uitvoering van preventie van overgewicht met 
name al vanaf de geboorte van een kind. Bij het ontwikkelen en uitvoering van een training ten behoeve van een meer actievere implementatiestrategie is er al een vertaalslag gemaakt naar de toepassing ervan in de dagelijkse praktijk van de jeugdgezondheidszorg. De gehele onderzoeksresultaten kunnen beschouwd worden als meer kennis over knelpunten en verbeterpunten in de vroegtijdige preventie van overgewicht. 
Dankwoord 


\section{DANKWOORD}

Promoveren is een uitdaging ! Terugkijkend naar de start van het promotietraject is het niet alleen de eindbestemming, deze promotie, maar voornamelijk de reis naar de eindbestemming waarin je veel leert over jezelf en over je vakgebied. Het was een uitdaging om een probleem, ervaren vanuit de praktijk te vertalen naar wetenschappelijk onderzoek.

Ik ben de mensen erg dankbaar die mij ondersteunt hebben om deze promotie tot een goed einde te brengen.

In dit hoofdstuk neem ik dan ook de gelegenheid om een aantal mensen te bedanken.

Op de eerste plaats gaat in het bijzonder mijn dank uit naar mijn copromotor en mijn promotoren, Dr. Willem-Jan Gerver, Prof. Dr. Maria Jansen en Prof. Dr. Luc Zimmermann die vanaf het begin vertrouwen in mij hebben gehad. Zij draagden er zorg voor om het beste uit mezelf te halen en mijn grenzen te verleggen.

Jullie bewaakten de wetenschappelijke kwaliteit en keken kritisch mee bij het schrijven van een artikel en het proefschrift als geheel. Jullie expertise, nauwe betrokkenheid en hulp heb ik zeer gewaardeerd.

Zonder jullie had ik niet de gelegenheid gehad om dit onderzoek, dat gestart is vanuit de Academische Werkplaats Publieke Gezondheid Limburg, uit te voeren en het belang van vroegtijdige preventie van overgewicht onder de aandacht te brengen. Ook aan Angèle mijn dank, voor de betrokkenheid en interesse en dank aan Marianne Beuken, die het destijds mede mogelijk heeft gemaakt om te starten met het onderzoek.

De leden van de beoordelingscommissie wil ik bedanken, Prof. dr. E. Dompeling, Dr. J.S. Gubbels, Dr. M. de Kroon, Prof. dr. P. Sauer en Prof. dr. F. Feron, als voorzitter, voor de tijd om mijn proefschrift te beoordelen.

Verder wil ik alle collega's van de Jeugdgezondheidszorg van Envida bedanken voor hun interesse en betrokkenheid bij mijn onderzoek en regelmatig werden er vragen over gesteld. In het bijzonder wil ik Lidwien Janssen en Bernice Doove bedanken, die zeker bij de start van het onderzoek nauw betrokken waren en altijd fijne feedback gaven.

Ook de collega's van de andere JGZ organisaties, Meander, Zuyderland en Icare en de GGD Zuid Limburg wil ik bedanken voor de medewerking aan het onderzoek. In drukke tijden en door de hoeveelheid aan veranderingen in de praktijk van het jeugdveld was het soms moeilijk om het onderzoek onder de aandacht te houden.

Echter, het onderwerp preventie van overgewicht bij het jonge kind, werd als belangrijk gezien en er werd ruimte gemaakt voor het uitvoeren van het onderzoek. Bo- 
vendien wil ik de de ouders die meegewerkt hebben aan interviews om meer inzicht te verkrijgen in het onderwerp bedanken voor hun tijd en uitwisseling van informatie.

De collega's van de afdeling Sociale Geneeskunde van de universiteit van Maastricht wil ik bedanken voor de betrokkenheid en voornamelijk mijn kamergenoten van destijds Nicole Hoefsmit en Danielle Eskens, waar ik met vragen altijd terecht kon.

Ook de oud collega's van de Academische Werkplaats wil ik bedanken voor de interesse en behulpzaamheid.

Prof. Dr Stef Kremers en Dr. Patricia van Assema, van de afdeling Gezondheidswetenschappen van de Universiteit van Maastricht wil ik eveneens danken voor de ondersteuning en het meedenken bij mijn onderzoek.

Willy Brink wil ik bedanken voor de hulp bij het onderzoek. Het was fijn om met jou te sparren over het onderwerp met daarbij niet alleen een wetenschappelijke, maar ook een verpleegkundige invalshoek. Af en toe bezocht je het mooie Maastricht, zodat we konden afstemmen over het onderzoek en ik heb hierdoor Utrecht en Zwolle mogen leren kennen. Manon Ernst wil ik bedanken voor de gedachtewisselingen en de samenwerking.

Verder wil ik de collega's van de vakgroep jeugdverpleegkundige V\&VN danken voor de interesse, het meedenken en de betrokkenheid.

Lyvia Vaes en Susanne Hanssen wil ik bedanken voor het verzamelen en invoeren van de vele data voor mij.

Sander van Kuijk wil ik bedanken voor de ondersteuning bij het analyseren van deze data.

Mia, Marie-Jose, Kyra en Heidi wil ik bedanken voor de praktische hulp en secretariele ondersteuning.

Ook wil ik Vivian, Rianne en Joyce als directe huidige collega's danken voor de interesse en ondersteuning.

En dan gaat mijn dankwoord over naar mijn vrienden en familie.

Meermaals hebben jullie interesse getoond voor mijn onderzoek. Het is jullie niet ontgaan dat het schrijven van een proefschrift tijd kost. Wiel, Jose, Rob, Ralph, Josette, Jeldican, Christel, Peter, Dorothee, Simone en Germaine bedankt voor jullie zorgen en begrip !

Ik wil ook mijn vrienden bedanken voor de afleiding, de gezellige momenten en de ontspanning. De etentjes, uitjes, paardrijritten, wandelingen en het bijpraten. Even wat anders. Monique en Deborah wil ik ook danken voor de mede zorg voor mijn dieren en 


\section{DANKWOORD}

het bijhouden van mijn agenda. Paul Lange wil ik bedanken voor de motiverende paardrijlessen en Wil Dassen voor de goede verzorging van mijn paard.

Cindy (en Jurgen) wil ik bedanken voor de kookkunsten, waarvan ik regelmatig het resultaat van mocht proeven en Wendy (en Koen ) voor de creatieve ondernemende gezelligheid. En dit geldt ook voor John en Miriam. Nicole, soms zien we elkaar minder, maar als we elkaar zien is het weer als vanouds. Dank voor je steun en geduld.

Als laatste wil ik mijn man, Richard bedanken. Een promoverende partner is niet altijd makkelijk. Dank voor je geduld, vriendschap en liefde voor mij !

Eveliene 
Curriculum vitae 


\section{CURRICULUM VITAE}

Eveliene de Bie werd geboren op 4 januari 1971 te Gulpen. Na de afronding van de middelbare school, Sophianum te Gulpen, begon ze aan haar studie verpleegkunde, Hogeschool te Sittard. Na deze studie was de interesse gewekt voor Gezondheidswetenschappen en in 1994 studeerde ze af in de richting Gezondheidsvoorlichting en Opvoeding bij de universiteit van Maastricht.

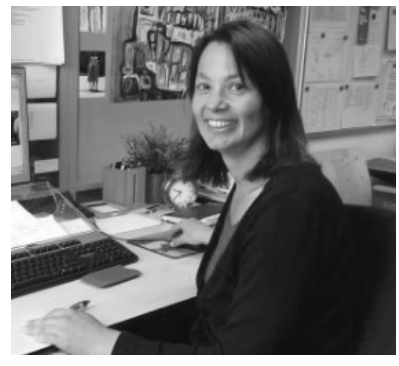

$\mathrm{Na}$ afronding van de studie werkte ze als verpleegkundige op de afdelingen Chirurgie en Orthopedie van het Universiteitsziekenhuis te Aken. Aansluitend werkte ze 1 jaar als verpleegkundige op de afdeling Neurologie van het ziekenhuis te Maastricht.

In 2000 maakte ze de overstap naar de Jeugdgezondheidszorg, waar ze tot 2011 als jeugdverpleegkundige in de uitvoering werkzaam was. Aansluitend kreeg ze een baan als stafverpleegkundige bij de Jeugdgezondheidszorg van Envida B.V. te Maastricht. Momenteel combineert ze deze baan met een andere baan, namelijk coördinator van de neonatale screeningen Zuid-Limburg. Verder is ze betrokken bij een aantal onderwijsactiviteiten, o.a. bij de Hogeschool Zuyd te Heerlen, studie verpleegkunde en bij de Academie Verloskunde Maastricht. Tevens is ze lid van de wetenschappelijke commissie jeugdverpleging V\&V en betrokken bij de beroepsvereniging Maatschappij en Gezondheid V\&VN, vakgroep jeugdverpleegkundigen.

In 2007 is ze gestart met het promotie traject voor de Academische Werkplaats Publieke Gezondheid Limburg, met als uitdaging het wetenschappelijk onderzoek meer te laten aansluiten bij de praktijk. Tijdens haar promotietraject bij de universiteit van Maastricht werd ze begeleid door Dr. W. J. Gerver, Prof. Dr. L. Zimmermann en Prof. Dr. M. Jansen, uiteindelijk resulterend in dit proefschrift. Het onderwerp van haar onderzoek is gericht op het voorkomen van overgewicht bij kinderen, startend vanaf de geboorte. 


\section{PUBLICATIONS}

Dera-de Bie E, Jansen MWJ, Gerver WJ. Belemmerende factoren in de preventie van overgewicht bij jonge kinderen: een exploratief kwalitatief onderzoek bij de jeugdgezondheidszorg. JGZ Tijdschrift voor jeugdgezondheidszorg. 2012;44(6):105-112

Dera-de Bie E, Jansen MWJ, Gerver WJ. Inhibiting factors in the prevention of overweight in infants: An explorative study conducted with $\mathrm{CHC}$ practitioners in the Netherlands. CHC in Practice2012;18(3):193-206.

Dera-de Bie E, Brink-Melis W, Jansen M, Gerver WJ. Characteristics of CHC practitioners in overweight prevention of children. Applied Nursing Research2016: 157-162.

Dera-de Bie, Gerver WJ, Jansen M. Training program for overweight prevention in the child's first year: compilation and results. Nurs Health Sci2013;Sep;15(3):387-97. 
